\title{
38. MIDDLE EOCENE TO PLEISTOCENE CALCAREOUS NANNOFOSSILS RECOVERED BY OCEAN DRILLING PROGRAM LEG 113 IN THE WEDDELL SEA ${ }^{1}$
}

\author{
Wuchang Wei ${ }^{2}$ and Sherwood W. Wise, Jr. ${ }^{2}$
}

\begin{abstract}
Long sequences of Upper Cretaceous through Quaternary sediments rich in calcareous and siliceous microfossils were recovered at Ocean Drilling Program Sites 689 and 690 on Maud Rise off East Antarctica. These sites have become the southernmost anchor in the Atlantic Basin for bio-, magneto-, chemostratigraphic, and paleobiogeographic studies. ODP Sites 692 and 693 on the Weddell Sea margin of East Antarctica and Site 696 on the South Orkney microcontinent of West Antarctica yielded calcareous nannofossils within some stratigraphic intervals. Sites 691, 692, 694, 695, and 697 did not recover Cenozoic calcareous nannofossils.

Calcareous nannofossil biostratigraphy suggests a major hiatus across the Paleogene/Neogene boundary at Sites 689 and 690 , and two additional hiatuses in the middle Eocene-lower Oligocene section at Site 690 . Correlation with magnetostratigraphy reveals: the last occurrence (LO) of Reticulofenestra umbilica at Maud Rise is over $1 \mathrm{~m} . \mathrm{y}$. younger than that at the middle-latitude sites; the LO of Isthmolithus recurvus is synchronous in the middle-latitude and high-latitude areas (about $34.8 \mathrm{Ma}$ ); Reticulofenestra oamaruensis ranges from 38.0 to $36.0 \mathrm{Ma}$ at Maud Rise; Reticulofenestra reticulata has a shorter range at Maud Rise (42.1 to $38.9 \mathrm{Ma})$ than at the middle-latitude DSDP Site 516; the range of Chiasmolithus oamaruensis is diachronous over different latitudes; and the LO of Chiasmolithus solitus is a good datum at $41.3 \mathrm{Ma}$ from $30^{\circ} \mathrm{S}$ to $65^{\circ} \mathrm{S}$ in the South Atlantic Ocean.

Comparison of calcareous nannofossil abundances in a latitudinal transect shows: Reticulofenestra bisecta is a temperate-water species and its LO, which crosses below that of Chiasmolithus altus at Maud Rise, is not applicable for the Paleogene/Neogene boundary in high southern latitude areas; Clausicoccus fenestratus is rare or absent at Maud Rise and can not be used as a marker; Coccolithus formosus is a warm-water species which disappeared earlier toward higher latitudes. Calcareous nannofossil assemblages indicate that by at least the middle Eocene, surface water temperatures became considerably lower in the high southern latitudes than in the middle-latitude areas and that there have been more extreme cold events in the high latitudes during the Neogene. Bicolumnus ovatus n. gen., n. sp. is proposed in this paper.
\end{abstract}

\section{INTRODUCTION}

Despite the importance of the Antarctic region in the evolution of earth history, the record of climatic and global evolution of Antarctica and of the distinctive circum-Antarctic Polar Current is poorly known. In total, DSDP Legs 28 (Hays, Frakes, et al., 1975) and 35 (Hollister, Craddock, et al., 1976) included only three continuously cored sites along the Antarctic margin, and no Hydraulic Piston Corer (HPC) or Advanced Piston Corer (APC) cores were collected. Ocean Drilling Program Leg 113 was the first to drill the extreme high latitude of the Atlantic sector of the Southern Ocean and used the HPC and APC to study the climatic, glacial, and oceanographic history and the biotic evolution of the Weddell Sea region. A total of nine sites were drilled (Fig. 1), recovering open-ocean pelagic biogenic sediment on Maud Rise (Sites 689 and 690), hemipelagic and terrigenous sediments on or close to the continental margins of both East and West Antarctica (Sites 691 through 693 and 695 through 697), and a deep sea turbiditic to hemipelagic sequence in the Weddell Abyssal Plain (Site 694). Figure 2 summarizes the sediments recovered at Sites $689,690,693$, and 696 which yielded Cenozoic calcareous nannofossils.

In this paper we document the calcareous nannofossils from middle Eocene to Pleistocene sediments recovered during Leg 113, discuss correlation of calcareous nannofossil markers with magnetostratigraphy, remark on paleobiogeographic patterns of selected species, and discuss paleoceanographic implications of

\footnotetext{
${ }^{1}$ Barker, P. F., Kennett, J. P., et al., 1990, Proc. ODP, Sci. Results, 113: College Station, TX (Ocean Drilling Program).

2 Department of Geology, Florida State University, Tallahassee, Florida 32306.
}

the calcareous nannofossil assemblages. The older (Maestrichtian-lower Eocene) calcareous nannofossil sequences are discussed in other papers by Pospichal and Wise (this volume). Most of our discussion centers on Sites 689 and 690, which recovered rather complete sequences of Upper Cretaceous through Pleistocene pelagic sediments, and calcareous nannofossils are very abundant up to the Miocene sections. The HPC cores from these two sites enable a magnetostratigraphy for the Upper Cretaceous to $\mathrm{Ce}$ nozoic sequences, and offer for the first time the opportunity to establish correlations between many calcareous nannofossil datum levels and magnetostratigraphy in the Southern Ocean. These two sites at $65^{\circ} \mathrm{S}$ latitude have become the southernmost reference in the Atlantic for calcareous nannofossil biostratigraphic and paleobiogeographic studies. Sites 693 and 696 recovered calcareous nannofossils within some stratigraphic intervals. These calcareous nannofossils help date some important events and provide useful paleoceanographic information. Sites 691, 692, 694, 695, and 697 did not recover Cenozoic calcareous nannofossils and will not be discussed further in this paper.

Cenozoic calcareous nannofossil biostratigraphic studies of the Southern Ocean have been published by Edwards (1971, 1973), Edwards and Perch-Nielsen (1975), Burns (1975), Haq (1976), Wise and Wind $(1977)$, and Wise $(1983,1988)$. However, due to the discontinuously cored and incomplete sequences recovered during previous DSDP legs, and the limited number of comparison sections, a Southern Ocean calcareous nannofossil zonation has not been well established, especially for the Antarctic region. The sedimentary sequence recovered at Sites 689 and 690 on Maud Rise and the calcareous nannofossil biostratigraphy should provide an excellent extreme high-latitude reference section for comparison with subsequent ODP Leg 119 and 120 materials from the Kerguelen Plateau (southern Indian 


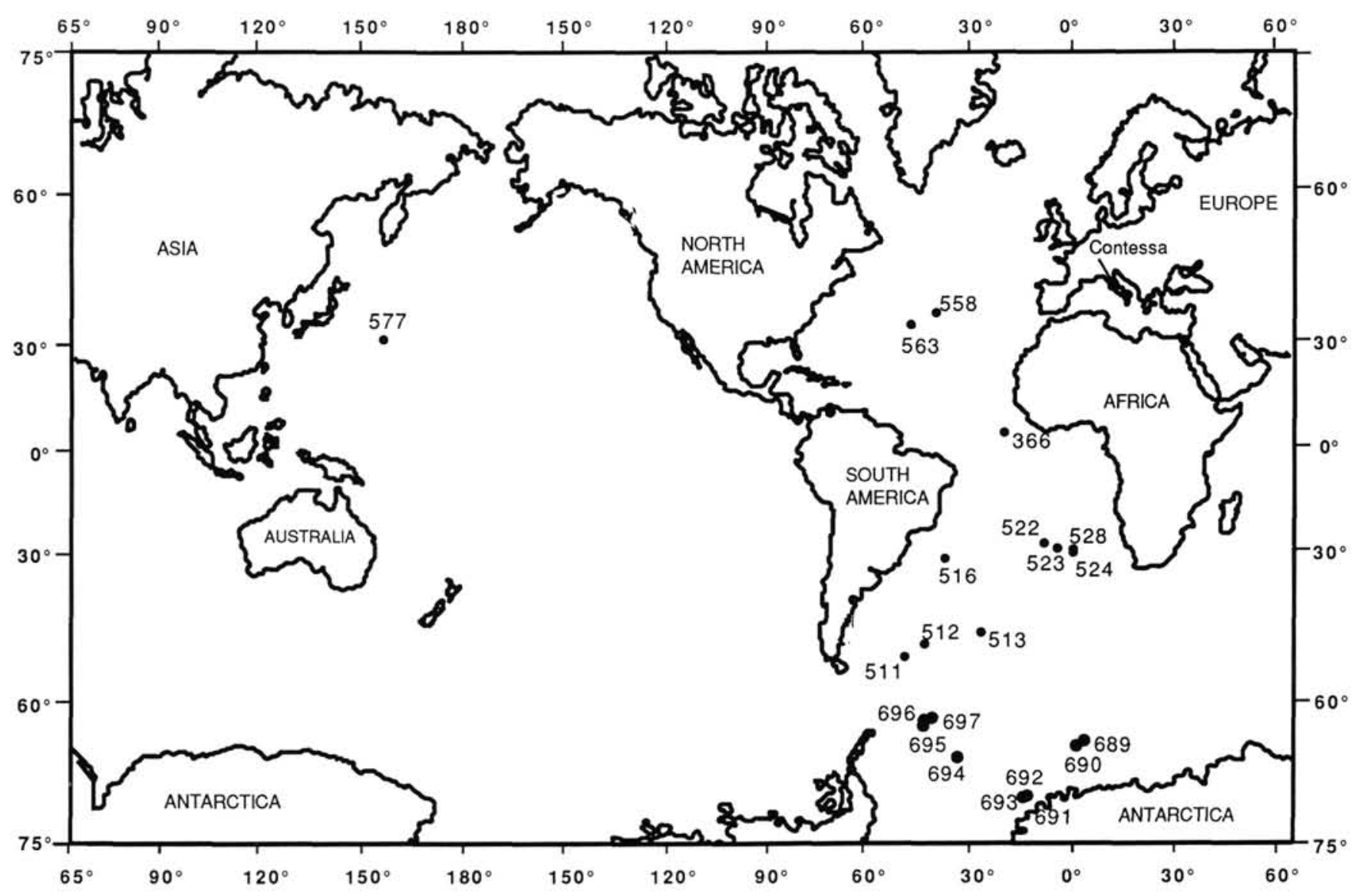

Figure 1. Locations of ODP Leg 113 drill sites (larger dots), DSDP sites (small dots), and land sections discussed in this paper.

Ocean) and for future biostratigraphic studies of the Southern Ocean.

A summary of the calcareous nannofossil occurrences by site measured against the low-latitude calcareous nannofossil zonation of Okada and Bukry (1980) is given in Figure 3. Figure 4 gives a summary of datum levels and zones adopted in this paper and their correlation with the zonations of Okada and Bukry (1980) and Wise (1983).

The calcareous nannofossil species considered in this paper are listed in the Appendix, where they are arranged alphabetically by genera. Almost all of the species are documented in Plates 1 through 6, and the illustrations are cross-referenced in the Appendix. Most bibliographic references for these taxa can be found in Loeblich and Tappan (1966-73), Heck (1979-83), or Steinmetz (1985-87); any not included therein are given in the references.

\section{METHODS AND PROCEDURES}

Smear slides were made directly from raw samples and were examined using a light microscope to determine the relative abundance of each nannofossil species present. Selected samples were examined in a scanning electronic microscope (SEM) to reveal ultrastructural details. For the study of some problematic taxa or suspected new taxa, Moshkovitz's (1978) correlation method was used; this allows the observation of the same specimens both under light microscope and in SEM. The abundance of the nannofossil species were tabulated on the range charts using the method proposed by Hay (1970), except that smear slides were examined at a magnification of $\times 1560$. Letters used on the range charts to denote nannofossil abundance are keyed to the $\log$ of the number of specimens of a particular taxon likely to be observed in any field of view of the microscope. These and the corresponding logs are determined as follows:

$$
\begin{aligned}
& \mathrm{V}= \text { Very abundant, }+1 \text { (more than } 10 \text { specimens per field } \\
& \text { of view). } \\
& \mathrm{A}= \text { Abundant }, 0 \text { ( } 1 \text { to } 10 \text { specimens per field of view). } \\
& \mathrm{C}=\text { Common, }-1 \text { ( } 1 \text { specimen per } 2 \text { to } 9 \text { fields of view). } \\
& \mathrm{F}=\text { Few, }-2 \text { ( } 1 \text { specimen per } 10 \text { to } 100 \text { fields of view). } \\
& \mathrm{R}=\text { Rare, }-3 \text { (1 specimen per } 101 \text { to } 1000 \text { fields of view). } \\
& \mathrm{B}=\text { Barren. }
\end{aligned}
$$

A qualitative determination was made on the state of preservation of the overall nannofossils in each sample. The following basic criteria were used to describe qualitatively the degree of dissolution and/or overgrowth of a nannofossil assemblage.

$\mathrm{G}=$ Good: individual specimens exhibit very little dissolution or recrystallization; delicate parts are preserved.

$\mathbf{M}=$ Moderate: individual specimens show evidence of dissolution (etching) and/or recrystallization (overgrowth); identification of species are generally not impaired.

$\mathrm{P}=$ Poor: individual specimens exhibit considerable dissolution and/or recrystallization; some less dissolution resistant taxa are not preserved.

\section{ZONATION}

The index fossils used in the Martini (1971) and Okada and Bukry (1980) zonations are mostly low to middle-latitude species, and are therefore rare or not present in ODP Leg 113 mate- 

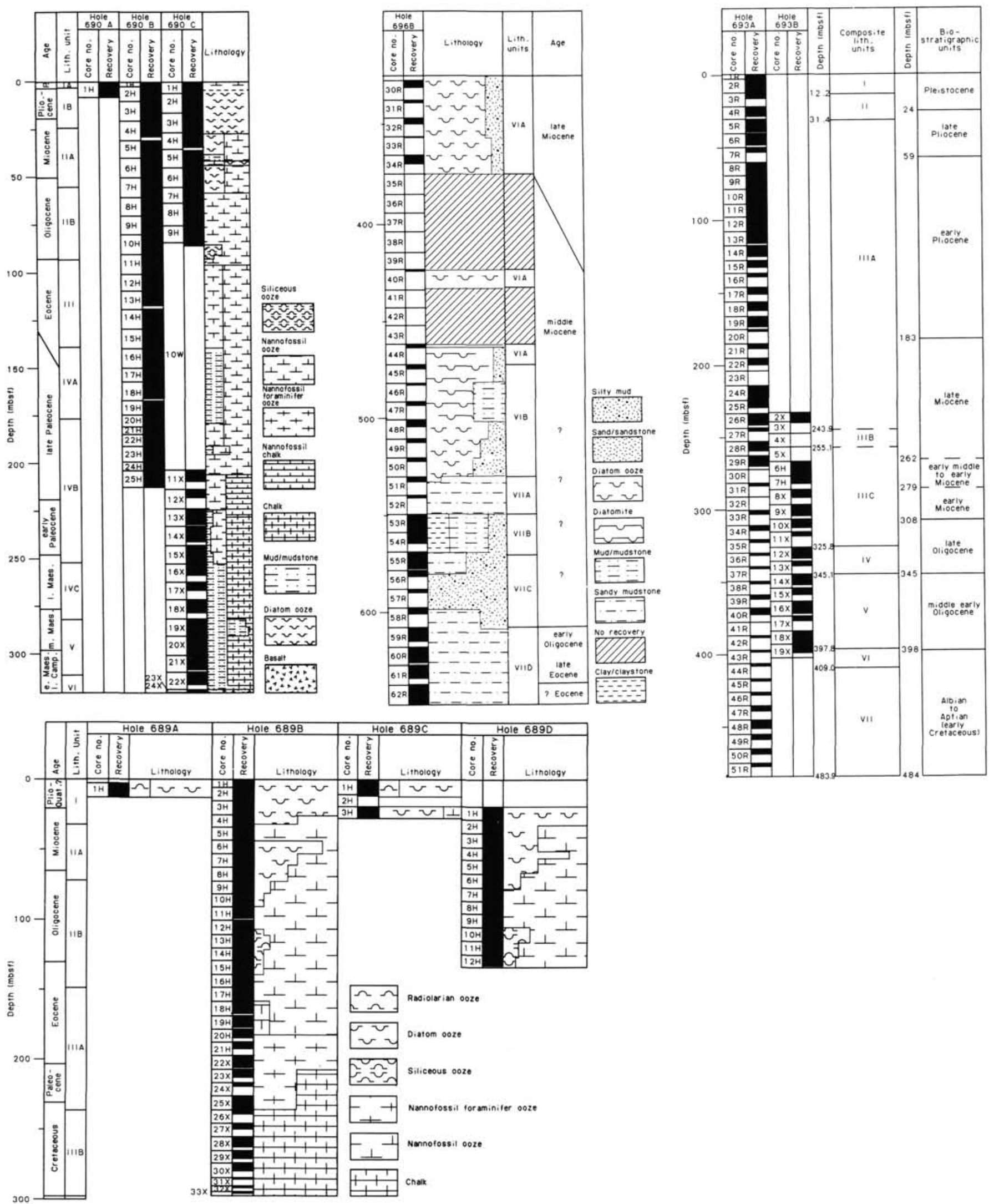

Figure 2. Lithologic columnar sections, Sites 689, 690, 693, and 696 of ODP Leg 113. 


\begin{tabular}{|c|c|c|c|c|c|}
\hline Age & Zone & Hole $689 \mathrm{~B}$ & Hole $690 \mathrm{~B}$ & Hole $693 \mathrm{~A}$ & Hole $696 \mathrm{~B}$ \\
\hline \multirow{3}{*}{$\frac{\frac{\dot{w}}{\omega}}{\frac{\omega}{a}}$} & CN15 & \multirow{4}{*}{$1 \mathrm{H}-1$} & \multirow{4}{*}{$1 \mathrm{H}-1$} & & \\
\hline & $\mathrm{CN}_{14}$ & & & & \\
\hline & $\mathrm{CN}_{13}$ & & & & \\
\hline \multirow{3}{*}{$\begin{array}{l}\stackrel{\Phi}{\Phi} \\
\stackrel{\circ}{0} \\
\frac{0}{0}\end{array}$} & $\mathrm{CN} 12$ & & & & \\
\hline & CN11 & & & & \\
\hline & $\mathrm{CN} 10$ & & & & \\
\hline \multirow{8}{*}{$\begin{array}{l}\text { 号 } \\
\frac{0}{\Sigma} \\
\frac{0}{2}\end{array}$} & CN9 & \multirow{7}{*}{$3 \mathrm{H} \cdot 6 / 8 \mathrm{H} \cdot 3$} & \multirow{7}{*}{$4 \mathrm{H}-3 / 7 \mathrm{H}-1$} & & \multirow{7}{*}{$22 \mathrm{R} \cdot \mathrm{CC}$} \\
\hline & CN8 & & & & \\
\hline & CN7 & & & & \\
\hline & CN6 & & & & \\
\hline & CN5 & & & & \\
\hline & CN4 & & & & \\
\hline & CN3 & & & & \\
\hline & CN2 & & & & \\
\hline \multirow{5}{*}{ 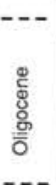 } & $\mathrm{CN} 1$ & & & & \\
\hline & CP19b & \multirow{3}{*}{$8 \mathrm{H}-4 / 12 \mathrm{H}-4$} & \multirow{3}{*}{$7 \mathrm{H}-2 / 10 \mathrm{H}-4$} & \multirow{3}{*}{ Cores $36 \mathrm{R}-42 \mathrm{R}$} & \\
\hline & CP19a & & & & \\
\hline & $\begin{array}{l}\text { CP18 } \\
\mathrm{CP} 17\end{array}$ & & & & \\
\hline & CP16 & \multirow{2}{*}{$12 \mathrm{H}-5 / 15 \mathrm{H}-2$} & $10 \mathrm{H} \cdot 5 / 11 \mathrm{H}-3$ & & \multirow{3}{*}{$58 R-1 / 62 R-6$} \\
\hline \multirow{4}{*}{$\begin{array}{l}\text { \& } \\
\text { \&్ }\end{array}$} & CP15b & & & & \\
\hline & CP15a & $15 \mathrm{H}-2 / 16 \mathrm{H}-7$ & $11 \mathrm{H}-3 / 12 \mathrm{H}-2$ & & \\
\hline & CP14b & $17 \mathrm{H} \cdot 1 / 17 \mathrm{H}-3$ & & & \\
\hline & CP14a & $17 \mathrm{H}-4 / 17 \mathrm{H}-\mathrm{CC}$ & $12 \mathrm{H}-3 / 12 \mathrm{H}-6$ & & \\
\hline
\end{tabular}

Figure 3. Summary of zonal and geologic age assignments of middle Eocene to Pleistocene core-sections recovered on ODP Leg 113, measured against the zonation of Okada and Bukry (1980). Where more than one core-section is assigned to a single zone, the numbers corresponding to the highest and lowest core-sections in that zone are separated by a slash $(/) . \mathrm{CC}=$ core catcher.

rial from the Weddell Sea. This is most evident for the Oligocene through Pleistocene sediments due to the global climatic deterioration and increasing latitudinal thermal gradient of the late Cenozoic. Only two long range species (Coccolithus pelagicus and Reticulofenestra perplexa) are present in parts of the Neogene material recovered during Leg 113, and most of the Neogene sequence is barren of calcareous nannofossils. This has prevented the establishment of a formal nannofossil zonation for the Neogene sections.
Edwards (1971) first proposed a calcareous nannofossil zonation for the sub-antarctic Paleogene of New Zealand. Wise (1983) established a Cenozoic zonation for the Falkland Plateau region. However, no single one of these high-latitude zonations is fully applicable to the Leg 113 material. One reason, as mentioned previously, is the extreme high-latitude deposition for this material and, therefore, the scarcity or absence of some temperate-water index species. On the other hand, as a result of this study, we now better understand the distribution of some species which appear useful for high-latitude biostratigraphic correlation. In this paper we make full use of the index fossils proposed by previous workers and adopt a necessarily expanded zonation for our Leg 113 material. Reference localities are given for new or modified zones. All zones used in this paper are summarized in Figure 4 and are defined as follows:

\section{Chiasmolithus altus Zone, Wise (1983)}

Definition. The interval from the last occurrence (LO) of Reticulofenestra umbilica to the last common Chiasmolithus altus.

Correlation. The Sphenolithus predistentus Zone (CP17) to the Sphenolithus ciperoensis Zone (CP19) of Okada and Bukry (1980).

Remarks. This zone was established by Wise (1983) for the Falkland Plateau region. Since there was strong reworking and dissolution of nannofossils near the Oligocene/Miocene boundary in that portion of the Southern Ocean due to the opening of Drake Passage during this time, the last common C. altus was used instead of the "absolute" LO of $C$. altus. The rare or few $C$. altus occurring sporadically after the last common occurrence are believed to be reworked. At Maud Rise the upper part of this zone is missing.

Reticulofenestra daviesii Zone (expanded), Wise (1983), emend. this paper

Definition. The interval from the LO of Isthmolithus recurvus to the LO of Reticulofenestra umbilica.

Correlation. Reticulofenestra placomorpha Zone of Edwards (1971); uppermost part of the Helicosphaera reticulata Zone (CP16) of Okada and Bukry (1980); combined Reticulofenestra daviesii and Clausicoccus fenestratus Zones of Wise (1983).

Reference locality. ODP Hole 689B, 107-113 mbsf.

Remarks. The lower boundary of this zone is defined differently from Wise's (1983) zone of the same name. The LO of Clausicoccus fenestratus, the base of Wise's Reticulofenestra daviesii Zone, cannot be used for the Maud Rise material because the nominative species is very rare, sporadic, and disappears from the section earlier. The distribution

\begin{tabular}{|c|c|c|c|c|}
\hline Age & $\begin{array}{l}\text { Zones used } \\
\text { in this study }\end{array}$ & Datums & $\begin{array}{l}\text { Zones of Okada \& } \\
\text { Bukry }(1980)\end{array}$ & $\begin{array}{l}\text { Zones of } \\
\text { Wise (1983) }\end{array}$ \\
\hline \multirow{3}{*}{ late Oligocene } & \multirow{2}{*}{\multicolumn{2}{|c|}{ No data }} & \multirow{3}{*}{$\begin{array}{l}\text { CP19 } \\
\text { CP18 } \\
\text { CP17 }\end{array}$} & Cyclicargolithus abisectus \\
\hline & & & & Reticulofenestra bisecta \\
\hline & Chiasmolithus altus & Last common Chiasmolithus altus & & Chiasmolithus altus \\
\hline \multirow{3}{*}{ early Oligocene } & Reticulofenestra daviesii & LO Reticulofenestra umbilica & \multirow[b]{2}{*}{ CP16 } & $\begin{array}{l}\text { Reticulofenestra daviesii } \\
\text { Clausicoccus tenestratus }\end{array}$ \\
\hline & Blackites spinosus & Lo isthmolithus recurvus & & Blackites spinosus \\
\hline & Reticulofenestra oamaruensis & Heticulorenestra oamaru & CP15b & Reticulofenestra oamaruensis \\
\hline \multirow{2}{*}{ late Eocene } & Isthmolithus recurvus & Po hellculorentestra oamatuensis & CPIJ0 & \multirow{3}{*}{ No data } \\
\hline & Chiasmolithus oamaruensis & EO Chiasmolithus samaruensis & CP15a & \\
\hline \multirow{3}{*}{ middle Eocene } & Discoaster saipanensis & LO Chiasmolithus solitus & $\mathrm{CP} 14 \mathrm{~b}$ & \\
\hline & Reticulofenestra reticulata & FO Reticulotenestra reticulata & \multirow{2}{*}{$\mathrm{CP} 14 \mathrm{a}$} & \multirow{2}{*}{ Discoaster bifax } \\
\hline & Reticulofenestra umbilica & FO Reticulofenestra umbilica & & \\
\hline
\end{tabular}

Figure 4. Calcareous nannofossil zones used in this study and their correlation with those of Okada and Bukry (1980) and Wise (1983). (FO = first occurrence, $\mathrm{LO}=$ last occurrence). 
of $C$. fenestratus through time in a latitudinal transect in the South Atlantic is presented and discussed later in this paper.

\section{Blackites spinosus Zone, Wise $(1983 ;=$ B. recta Zone of Edwards, 1971), emend. this paper}

Definition. The interval from the LO of Reticulofenestra oamaruensis to the LO of Isthmolithus recurvus.

Correlation. Middle part of the Helicosphaera reticulata Zone (CP16) of Okada and Bukry (1980); upper part of the Blackites rectus Zone (Edwards, 1971) or Blackites spinosus Zone (Wise, 1983).

Reference locality. ODP Hole 689B, 113-121 mbsf.

Remarks. The lower boundary of this zone is defined differently from Wise's (1983) zone of the same name. The datum used in Wise (1983) is the LO of Discoaster saipanensis, which cannot be applied in this study due to the absence of discoasters in the upper Eocene sediments. On the other hand, the LO of Reticulofenestra oamaruensis has been consistently found below the LO of Isthmolithus recurvus in the Falkland Plateau region (Wise, 1983) and on Maud Rise. It seems proper to use this datum in the high latitudes to refine the biostratigraphy.

Reticulofenestra oamaruensis Zone, Stradner and Edwards (1968), emend. this paper

Definition. Interval of the total biostratigraphic range of Reticulofenestra oamaruensis.

Correlation. Upper part of the Discoaster barbadiensis Zone (CP15) to the lower part of the Helicosphaera reticulata Zone (CP16) of Okada and Bukry (1980). Upper part of Reticulofenestra oamaruensis Zone of Wise (1983).

Reference locality. ODP Hole 689B, 121-128 mbsf.

Remarks. The upper boundary has been discussed above. The lower boundary is defined by the first occurrence (FO) of Reticulofenestra oamaruensis, a datum already widely used for middle- to high-latitude zonations (Edwards, 1971; Waghorn, in Perch-Nielsen, 1985; Wise, 1988). Stradner and Edwards (1968) used the total range of $R$. oamaruensis to define a subzone, and we upgrade it to a zone for the Southern Ocean sediments.

\section{Isthmolithus recurvus Zone, Martini (1970), emend. this paper}

Definition. The interval from the FO of Isthmolithus recurvus to the FO of Reticulofenestra oamaruensis.

Correlation. The combined Isthmolithus recurvus and Discoaster saipanensis Zones of Edwards (1971); lower part of the Isthmolithus recurvus Subzone (CP15b) of Okada and Bukry (1980).

Reference locality. ODP Hole 689B, 128-133 mbsf.

Remarks. Martini (1970) originally defined the upper boundary of this zone by the LO of Sphenolithus pseudoradians. Subsequently, Sphenolithus pseudoradians has been found to be restricted to certain areas and its range is quite variable in different places. Therefore, the LO of S. pseudoradians is believed no longer useful (Martini and Müller, 1986). Edwards (1971) used the LO of Reticulofenestra hampdenensis to subdivide this zone. There are, however, taxonomic problems with $R$. hampdenensis. Species, such as Reticulofenestra daviesii, very similar and probably synonymous with $R$. hampdenensis range up to the upper Oligocene.

\section{Chiasmolithus oamaruensis Zone, Martini (1970)}

Definition. The interval from the $\mathrm{FO}$ of $C$. oamaruensis to the $\mathrm{FO}$ of I. recurvus.

Correlation. Chiasmolithus oamaruensis Subzone (CP15a) of Okada and Bukry (1980).

\section{Discoaster saipanensis Zone, Martini (1970)}

Definition. The interval from the LO of Chiasmolithus solitus to the FO of $C$. oamaruensis.

Correlation. Okada and Bukry's (1980) subzone of the same name (CP14b).

\section{Reticulofenestra reticulata Zone, Wei and Wise, this paper}

Definition. The interval from the FO of $R$. reticulata to the LO of $C$. solitus.

Correlation. Upper part of the Discoaster bifax Subzone (CP14a) of Okada and Bukry (1980).
Reference locality. ODP Hole 689B, 153-159 mbsf.

Remarks. Edwards and Perch-Nielsen (1975) suggested use of the FO of $R$. reticulata as a datum in the middle Eocene. The datum also has been used in southern Australia (Shafik, 1985). Calibration of this datum with magnetostratigraphy at DSDP Site 516 in the South Atlantic (Wei and Wise, 1989) and at Maud Rise (see discussion below) suggests the FO of $R$. reticulata is younger in high latitudes than in middlelatitudes. Therefore this datum is for provincial use only.

Reticulofenestra umbilica Zone, Wei and Wise, this paper

Definition. The interval from the FO of Reticulofenestra umbilica to the FO of $R$. reticulata.

Correlation. Lower part of the Discoaster bifax Subzone (CP14a) of Okada and Bukry (1980).

Reference locality. ODP Hole 689B, 159-163 mbsf.

\section{SITE SUMMARIES}

\section{Site 689 (Table 1)}

ODP Site $689\left(64^{\circ} 31.009^{\prime} \mathrm{S} ; 3^{\circ} 5.996^{\prime} \mathrm{E}\right.$; water depth, 2084 $\mathrm{m}$ ) is located near the crest of Maud Rise, eastern Weddell Sea (Fig. 1). The objectives of drilling at the site were to obtain a predominantly calcareous carbonate and in part biosiliceousrich Cenozoic and older section beneath the modern Antarctic water mass. Four holes were drilled at this site, and Hole 689B yielded the longest sedimentary section. This was the first time a complete upper Eocene sequence had been sampled in the high-latitude South Atlantic.

Calcareous nannofossils are very abundant in the Eocene and Oligocene sections, but they alternate with siliceous microfossils in abundance in many intervals in the Miocene and are generally absent in Pliocene to Pleistocene sediments. Species diversity is low but comparable with that in the Falkland Plateau material. Preservation of the calcareous nannofossils is moderate to poor. This is due to the fact that the high calcium carbonate content facilitates dissolution and reprecipitation of calcium carbonate among the nannofossil specimens (Wise, 1977), which results in the dissolution of the less resistant nannofossil species and overgrowth on other species. Most central bars of chiasmoliths in Leg 113 material are not preserved, making identification at the species level often difficult or impossible. However, Reticulofenestra daviesii, one of the most abundant species in the Leg 113 material, tends to exhibit overgrowths in the central area.

Most specimens of Isthmolithus recurvus and Zygrhablithus bijugatus have been overgrown to such an extent that they may escape recognition by some investigators. Overgrown forms of the latter have given rise to many junior synonyms (see PerchNielsen, 1985, p. 454) or have often been reported as Zygrhablithus $\mathrm{sp}$. in the literature.

Foraminiferal ooze at the top of the section (top of Cores $113-689 \mathrm{~B}-1 \mathrm{H}$ and $113-689 \mathrm{C}-1 \mathrm{H})$ contains rare calcareous nannofossils. Sample 113-689B-1H, $10 \mathrm{~cm}$ yielded a well-preserved specimen of Pseudoemiliania lacunosa, which ranges from lower Pliocene to upper Pleistocene $(0.44 \mathrm{Ma})$. Calcareous nannofossils are absent in the subjacent Pliocene diatom/silicoflagellate ooze, which extends down to Sample 113-689B-3H-5, 139-141 $\mathrm{cm}$. The next sample (113-689B-3H-6, 29-31 cm) contains abundant Coccolithus pelagicus and Reticulofenestra perplexa (= Dictyococcites antarcticus $\mathrm{Haq}$ ). The latter species ranges from Miocene to Pliocene in age.

Sporadic Reticulofenestra gelida and Reticulofenestra pseudoumbilica were found in Cores $113-689 \mathrm{~B}-3 \mathrm{H}$ to $-7 \mathrm{H}$. These species have a general range of middle Miocene-lower Pliocene. Most of Core 112-689B-4H is barren of calcareous nannofossils. The last two samples from this core contain an almost monospecific assemblage of Reticulofenestra perplexa, the po- 
Table 1. Distribution of middle Eocene-Pleistocene calcareous nannofossils, ODP Hole 689B.

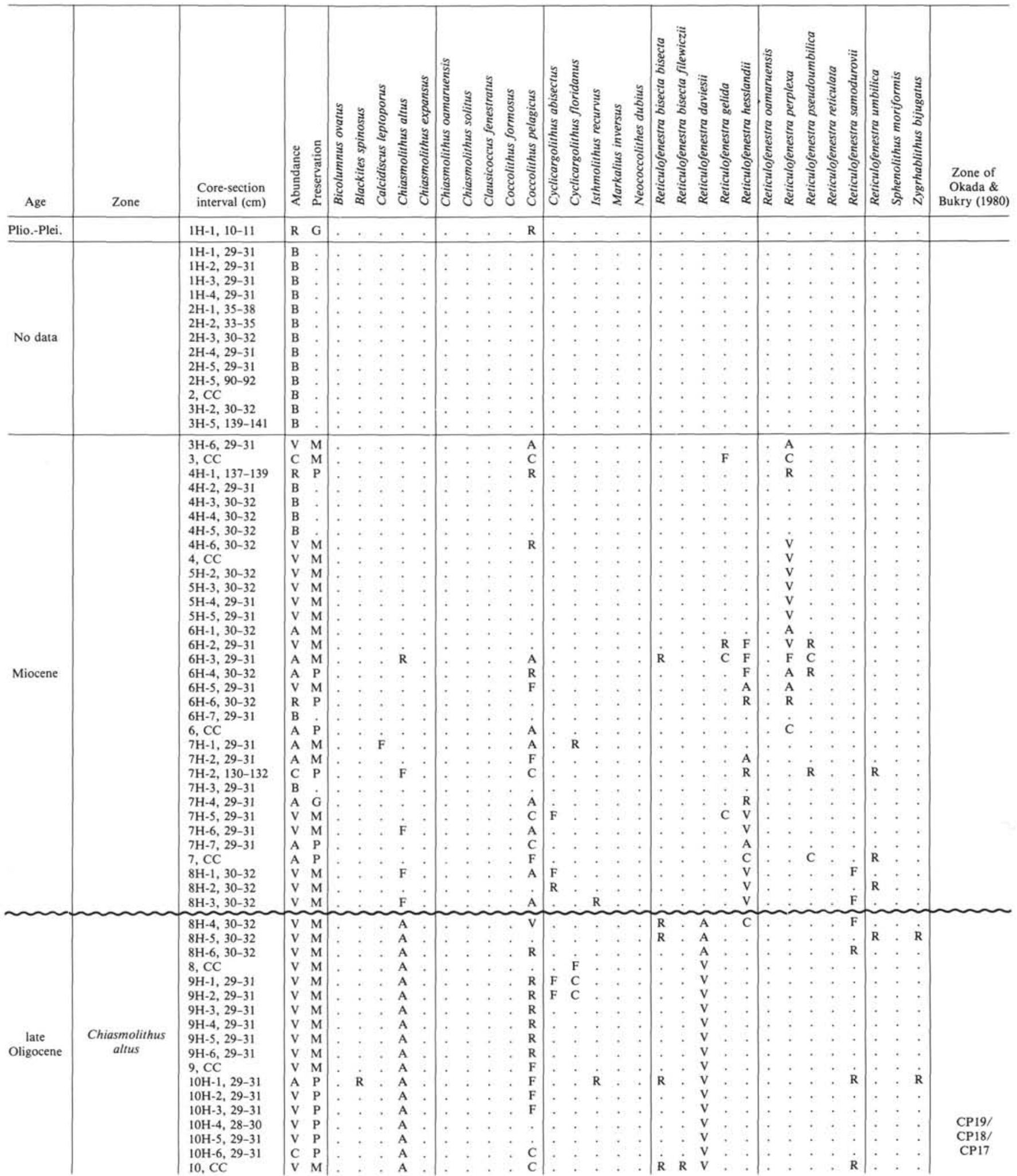

lar end member of cold-water species in Antarctic waters. Core $113-689 \mathrm{~B}-5 \mathrm{H}$ yielded only $R$. perplexa.

Cores 113-689B-6H through the middle of 113-689B-8H contain mostly Coccolithus pelagicus and one or two species of $R e$ ticulofenestra (R. perplexa and $R$. hesslandii). There are extreme alternations in dominance between $C$. pelagicus and the reticulofenestrids and abrupt changes of the presence and absence of calcareous nannofossils in this interval. This may reflect temperature fluctuations in the surface waters or changes in carbonate preservation. However, we believe that temperature fluctuation is 
Table 1 (continued).

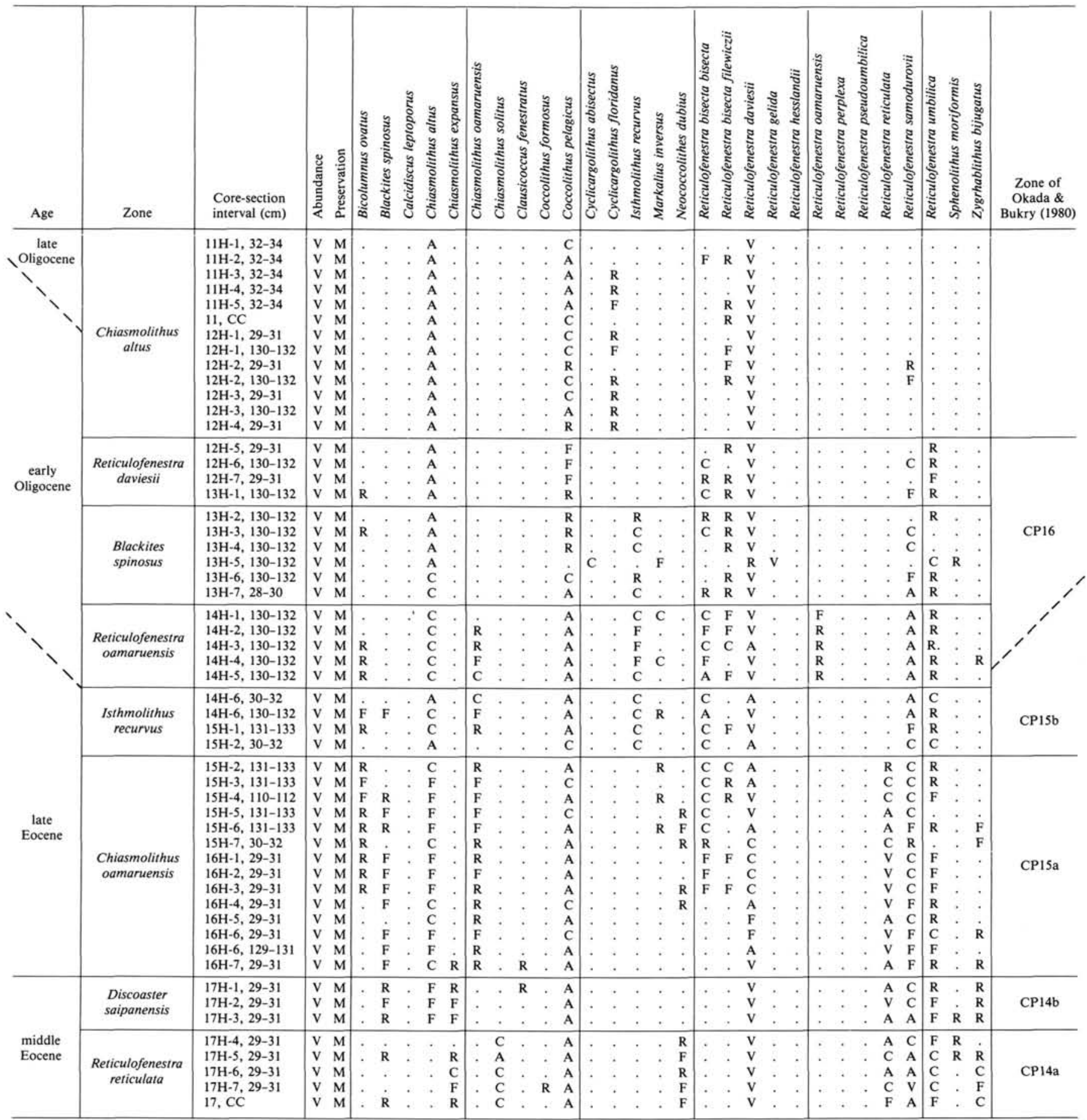

Note: Occurrence: $\mathrm{V}=$ very abundant $\mathrm{A}=$ abundant $\mathrm{C}=$ common; $\mathrm{F}=$ few $\mathrm{R}=$ rare; $\mathrm{B}=$ barren. Preservation: $\mathrm{P}=$ poor $; \mathrm{M}=$ moderate.

the major factor, because both $C$. pelagicus and the reticulofenestrid group are rather dissolution resistant and the dominance of either in the sample is not accompanied by any indication of severe diagenesis. A few chiasmolith rims (presumably rims of Chiasmolithus altus) were found in this interval, and they are believed to be reworked from older sediment which contains abundant $C$. altus. Rare specimens of Reticulofenestra umbilica $(>14 \mu \mathrm{m})$ were also observed in several samples within this interval. These specimens are also most likely reworked.

Abundant Chiasmolithus altus (mostly only rims) and Reticulofenestra daviesii were found up to Sample 113-689B-8H-4,
$30-32 \mathrm{~cm}$, where they disappear abruptly. A disconformity is indicated between this sample and Sample 113-689B-8H-3, 30-32 $\mathrm{cm}$. Diatom biostratigraphy of Gersonde and Burckle (this volume) also suggests that the lowermost Miocene is missing at this level. The Oligocene/Miocene boundary coincides with this disconformity. The opening of Drake Passage occurred about that time and it may have resulted in the erosion of sediment at Maud Rise by an accelerated circumpolar current.

The Chiasmolithus altus Zone was recognized from Samples 113-689B-8H-4, 30-32 cm, to 113-689B-12H-4, 29-31 cm, and this interval spans the Sphenolithus predistentus (CP17) through 
the Sphenolithus ciperoensis Zones (CP19) of Okada and Bukry (1980). The total absence of sphenoliths and the absence of other usable datums prohibit a finer stratigraphic resolution for this part of the section.

The rare but consistent occurrence of Reticulofenestra umbilica was observed up to Sample 113-689B-12H-5, 29-31 cm. This datum is taken to define the upper boundary of the Reticulofenestra daviesii Zone. The lower boundary of this zone, the LO of Isthmolithus recurvus, is located above Sample 113-689B$13 \mathrm{H}-2,130-132 \mathrm{~cm}$.

From Sample 113-689B-13H-5, 130-132 cm, to Sample 113689B-16H-7, 29-31 cm, Chiasmolithus altus and Chiasmolithus oamaruensis co-occur. Differentiation of the two species is difficult because their central bars are rarely preserved. Their abundances recorded in the range chart for this section are rough estimates based on the ratios of well preserved specimens.

Reticulofenestra oamaruensis, the total biostratigraphic range of which defines the Reticulofenestra oamaruensis Zone, occurs in Samples 113-689B-14H-1, 130-132 cm, through 113-689B$14 \mathrm{H}-5,130-132 \mathrm{~cm}$. The Eocene/Oligocene boundary lies somewhere within this interval, though the precise location cannot be determined due to the absence of the conventional calcareous nannofossil marker species (Discoaster saipanensis) for the boundary. No other discoasters are present in the upper Eocene sediment at Site 689.

The LO of Reticulofenestra reticulata has been well documented in different parts of the world as being stratigraphically higher than the FO of Isthmolithus recurvus (Müller, 1979; Wise, 1983; Edwards and Perch-Nielsen, 1975). However, at this site the range of $R$. reticulata is truncated above Sample 113$689 \mathrm{~B}-15 \mathrm{H}-2,131-133 \mathrm{~cm}$, and the lowest stratigraphic occurrence of $I$. recurvus is in the overlying sample. Paleomagnetic data suggest that the LO of $R$. reticulata is stratigraphically lower at this site than in lower latitudes (see additional discussion below).

The interval from Sample 113-689B-15H-2, 131-132 cm, to Sample 113-689B-16H-6, 129-131 cm, is placed in the Chiasmolithus oamaruensis Zone. Reticulofenestra reticulata is mostly abundant in this zone. A larger-sized population $(8-9 \mu \mathrm{m})$ occurs in the upper part of the zone, whereas only smaller (6-7 $\mu \mathrm{m}) R$. reticulata are present in the lower part of this zone. A similar situation has been observed at Site 516 in the South Atlantic Ocean (Wei, unpubl. data).

The LO of Chiasmolithus solitus is easily recognized in Sample 113-689B-17H-4, 29-31 cm, where it is common. Another easily recognized datum is the FO of $R$. reticulata in Sample 113-689B-17H, CC. The interval between these two samples is assigned to the Reticulofenestra reticulata Zone. Zygrhablithus bijugatus, which is rare or absent in the upper sediment sequence, is common in this zone.

\section{Site 690 (Table 2)}

ODP Site $690\left(65^{\circ} 9.629^{\prime} \mathrm{S}\right.$; $1^{\circ} 12.296^{\prime} \mathrm{E}$; water depth, 2920 $\mathrm{m}$ ) is located on the southwestern flank of Maud Rise, eastern Weddell Sea, $116 \mathrm{~km}$ southwest of Site 689 (Fig. 1). Site 690 was drilled to obtain a high quality continuously cored sequence through the upper Mesozoic and Cenozoic beneath the present day Antarctic water mass, and to form part of a depth transect for studies of the vertical water mass stratification during the late Mesozoic and Cenozoic around Antarctica.

Three holes were drilled at this site, and Hole 690B recovered the most complete Cenozoic section. Calcareous nannofossils are rare in the foraminiferal ooze of Lithostratigraphic Unit IA, absent in the subjacent Pliocene diatomaceous ooze (Unit IB), abundant at some levels in the Miocene, and abundant throughout the remainder of the sequence. Preservation is generally good in the Miocene and moderate to poor in the Oligocene through middle Eocene. Reworking is minimal in the Paleogene section. The following is a description of the calcareous nannofossils from the Pleistocene down to the middle Eocene sequence from Hole 690B.

The foraminiferal ooze at the top of the first core section (Section 113-690B-1H-1) contains rare Pseudoemiliania lacunosa and Coccolithus pelagicus. The former has a stratigraphic range from lower Pliocene to upper Pleistocene. Some specimens of the latter species exhibit a central area bar, a feature characteristic of many Pliocene-Pleistocene representatives of the species. Coccolithus pelagicus has been virtually absent from the Southern Hemisphere since about middle Holocene time, but persists today in the Northern Hemisphere surface waters between $6^{\circ}$ and $14^{\circ} \mathrm{C}$ (McIntyre et al., 1970). The presence of C. pelagicus in the sediment suggests that at sometime during the middle Pliocene to the late Pleistocene, interglacial conditions were sufficiently warm to allow this taxon to exist at this site. There are no records, however, of coccolithophorids living at this latitude today.

Similar to Site 689 , the interval from Core $113-690 \mathrm{~B}-2 \mathrm{H}$ to the upper part of Core 113-690B-4H is a diatom/silicoflagellate ooze devoid of calcareous nannofossils. The lower part of Core $113-690 \mathrm{~B}-4 \mathrm{H}$ to the upper part of Core 113-690B-5H contains a monospecific assemblage of Reticulofenestra perplexa, a species limited to high-latitude waters. Another interval barren of calcareous nannofossil was found in the lower part of Core 113690B-5H. In the two subjacent cores, Reticulofenestra hesslandii and $C$. pelagicus dominate the assemblage. Rare specimens of chiasmolith rims and Reticulofenestra umbilica were observed, but are considered to be reworked. Abundant Chiasmolithus altus were encountered in Sample 113-690B-7H-2, 28-30 cm. A disconformity is suggested between this sample and Sample 113-690B-7H-1, 130-132 cm, based on the abrupt change in abundance of $C$. altus, and some reworked specimens of $R$. umbilica observed above this level. The ranges of several diatom species are truncated here and they suggest the absence of lowest Miocene sediment (Gersonde and Burckle, this volume). This hiatus spans the Oligocene/Miocene boundary, and the cause is believed to be the same as at Site 689 , resulting from the water circulation changes and erosion related to the opening of the Drake Passage.

Rare specimens of Reticulofenestra bisecta were first encountered downhole in Sample 113-690B-9H-3, 28-30 cm. This species disappears earlier than $C$. altus at this site as well as at Site 689 , a reversal of the events as recorded at other lower latitude localities (Wise, 1983; Perch-Nielsen, 1985). This has prevented the use of the LO of $R$. bisecta to approximate the Oligocene/ Miocene boundary as defined in the zonations of Edwards (1971) or Wise (1983). Rare and sporadic occurrences of $R$. umbilica were observed in Core 113-690B-9H and in the upper part of Core $113-690 \mathrm{~B}-10 \mathrm{H}$, and they are believed to be reworked.

A major disconformity must be present between Samples 113-690B-11H-1, 130-132 cm, and $-11 \mathrm{H}-3,29-31 \mathrm{~cm}$, because the Reticulofenestra oamaruensis Zone is missing here (parts of the adjacent zones are probably also missing). The precise location of the disconformity cannot be determined by the nannofossil biostratigraphy, but the magnetostratigraphy of V. Spieß (written comm., 1989) suggests its presence above Section 113$690 \mathrm{~B}-11 \mathrm{H}-2$, with Chrons 13 and 15 missing there. This hiatus spans most of the late Eocene to the earliest Oligocene. Graphic correlation of Site 690 with Site 689 presented below shows clearly the magnitude of this hiatus, which cannot be matched at Site 689.

A third disconformity suggested by the nannofossil biostratigraphy at this site occurs between Samples 113-690B-12H-2, $130-132 \mathrm{~cm}$, and 113-690B-12H-3, 29-31 cm, where the Discoaster saipanensis Zone (NP17) is missing. The duration of this 
zone is poorly known at present, but is probably brief since the magnetostratigraphy of V. Spieß (written comm., 1989) does not reveal this hiatus.

Similar to the situation at Site 689 , the FO of Reticulofenestra bisecta occurs above that of Chiasmolithus oamaruensis, within CP15a of Okada and Bukry (1980). This contradicts the sequence of events in Edwards (1971) and Edwards and PerchNielsen (1975), where the FO of $R$. bisecta is below that of $C$. oamaruensis, within Zone CP14. Reticulofenestra bisecta was not found in CP14a at Site 512, but Subzones CP14b and CP15a were not cored in that hole. It was found in a piston core from Subzone CP14a, however, taken on the northern Falkland Plateau (Wise and Mostajo, 1983). As discussed elsewhere in this paper, the combined data suggest that the FO and LO of $R$. bisecta are time transgressive over different latitudes.

A fourth disconformity, between Samples 113-690B-12H-6, $29-31 \mathrm{~cm}$, and $113-690 \mathrm{~B}-12 \mathrm{H}-7,29-31 \mathrm{~cm}$, is indicated by sedimentologic features, i.e., scour marks and color change (Barker, Kennett, et al., 1988, p. 193, fig. 8). No calcareous nannofossil zones or subzones are missing, thus this hiatus must have been a brief one.

\section{Site 693}

Site 693, lying on a mid-slope bench on the Weddell Sea margin of East Antarctica, was chosen to examine the Cenozoic record of Antarctic continental cooling and ice-sheet formation. Two holes were drilled: Hole $693 \mathrm{~A}$ penetrated $483.9 \mathrm{~m}$ below seafloor (mbsf) in 51 cores and recovered sediment ranging from the Pleistocene to the Lower Cretaceous; Hole 693B was washed to $233.8 \mathrm{mbsf}$, then cored to $403.1 \mathrm{mbsf}$ where it again bottomed in Lower Cretaceous sediments. A major disconformity separates the Lower Cretaceous from the overlying lower Oligocene sediments. Despite the relatively shallow water depth (2363 $\mathrm{m})$ at this site, calcareous nannofossils were found in only a few short intervals in the Pleistocene, Miocene, upper Oligocene, and Lower Cretaceous. Tables 3 and 4 give the calcareous nannofossil distribution in the Oligocene and younger sections from Holes 693A and 693B.

\section{Hole 693 A (Table 3)}

Hole $693 \mathrm{~A}$ was drilled at $70^{\circ} 49.892^{\prime} \mathrm{S}, 14^{\circ} 34.410^{\prime} \mathrm{W}$, in $2359 \mathrm{~m}$ of water. Rare but well preserved specimens of Gephyrocapsa oceanica were observed in the first core-catcher sample. This species ranges from upper Pleistocene to Recent. There is no record of living calcareous nannoplankton at such a high latitude. The observed $G$. oceanica is believed to be a contaminant.

The next 23 samples examined downhole are barren of calcareous nannofossils, whereas abundant Chiasmolithus altus and Reticulofenestra daviesii were found in some thin laminae within the clayey matrix of Cores 113-693A-36R and 113-693A$37 \mathrm{R}$. This assemblage is characteristic of upper Oligocene sediment at Maud Rise. Samples 113-693A-38R, CC and 113-693A$39 \mathrm{R}, \mathrm{CC}$ contain rare $C$. altus and $R$. daviesii, and Sample 113$693 \mathrm{~A}-42 \mathrm{R}, \mathrm{CC}$ yields only $C$. altus. All these samples can be assigned to a late Oligocene age.

\section{Hole 693B (Table 4)}

Hole $693 \mathrm{~B}$ was drilled at $70^{\circ} 49.888^{\prime} \mathrm{S}, 14^{\circ} 34.461^{\prime} \mathrm{W}$, in 2359 $\mathrm{m}$ of water. Abundant Coccolithus pelagicus was found in Sample $113-693 \mathrm{~A}-6 \mathrm{H}-4,56-58 \mathrm{~cm}$, a middle Miocene interval according to siliceous microfossil stratigraphy. This monospecific assemblage of $C$. pelagicus is quite similar to that in many intervals at Sites 689 and 690 , where the alternate dominance of $C$. pelagicus and the small reticulofenestrids is thought to represent fluctuations in the surface water temperature. Samples 113693B-12X-2, $122 \mathrm{~cm}$, through 113-693B-13X-3, $6 \mathrm{~cm}$, from an equivalent sub-bottom depth to Cores 113-693A-36R and 113693A-37R, also contain abundant to very abundant $C$. altus and $R$. daviesii, reconfirming an age of late Oligocene for this interval. However, the next 14 samples below Core 113-693B-13X are barren of calcareous nannofossils.

In conclusion, Site 693 was drilled in $2363 \mathrm{~m}$ of water, comparable to those at Sites 689 and 690 on Maud Rise (2081 and 2931 m respectively). On Maud Rise, carbonate sediments were recovered throughout the Oligocene and most of the Miocene interval. The carbonate compensation depth (CCD), however, was considerably higher at Site 693, and only descended briefly during the late Oligocene and middle Miocene to permit calcareous nannofossil ooze deposition at this locality. The elevated CCD at Site 693 was probably due to decreased production of calcareous nannoplankton in the colder and perhaps less saline waters along the Antarctic margin, where temperature may have dropped close to or below the life tolerance for these organisms during much of Oligocene and Miocene time. Similarly, or alternatively, bottom waters were probably highly undersaturated in dissolved calcium carbonate along this glaciated continental margin during most of the Oligocene/Miocene. The most extensive deposition of calcareous nannofossils at Site 693 occurred during the latest Oligocene, which would suggest brief ameliorations in climate, after the cooling associated with more pronounced early and late Oligocene glaciation.

\section{Site 696 (Table 5)}

Site $696\left(60^{\circ} 50.9^{\prime} \mathrm{S}, 42^{\circ} 55.9^{\prime} \mathrm{W}\right.$; water depth, $\left.650 \mathrm{~m}\right)$, the shallowest of all Leg 113 sites in the Weddell Sea region, was to provide a continuously cored, shallow-water sedimentary record of late Paleogene to Neogene paleoceanographic and paleoclimatic history for the South Orkney microcontinent, a feature close to the west Antarctic margin. Calcareous nannofossils are present in a few short intervals, but several zonal species were found. This facilitates the dating of some intervals, especially in the lower part of the sequence, where other microfossils are rare or absent and the age is otherwise unknown.

Neogene calcareous nannofossils were found only in Sample 113-696B-22R, CC (260.1 mbsf), which contains a monospecific assemblage of Reticulofenestra perplexa. Calcareous nannofossils were otherwise absent throughout the Miocene-Quaternary section, a reflection of an exceedingly shallow carbonate compensation depth at this rather shallow site (water depth $=650$ $\mathrm{m})$.

Below the level of coarse-grained ice-rafted detritus (IRD) and dropstones in Cores 113-696B-51R and 113-696B-53R through 113-696B-54R, several samples from Cores 113-696B-58R and 113-696B-59R (600-620 mbsf) contain well preserved calcareous nannofossil assemblages, including Chiasmolithus altus, Coccolithus pelagicus, Isthmolithus recurvus, Reticulofenestra bisecta, Reticulofenestra daviesii, and Reticulofenestra oamaruensis. The presence of the latter species in these samples places them in the Reticulofenestra oamaruensis Zone, which spans the Eocene/Oligocene boundary. The occurrence of $I$. recurvus in Sample 113-696B-59R-4, $50 \mathrm{~cm}$, indicates an age older than 34.8 Ma.

A rather well preserved and diverse assemblage of calcareous nannofossils was found in Sample 113-696B-62R-6, 130-132 cm, which includes rare Reticulofenestra reticulata in a size range of 8-9 $\mu \mathrm{m}$. The last occurrence of this species has been consistently found slightly below the Eocene/Oligocene boundary in many areas over different environments. Biometric study of $R$. reticulata (Wei, unpubl. data) from Sites 516 and 689 reveals that the species rapidly increases in size near its extinction level, and those $8-9 \mu \mathrm{m}$ specimens only occurred close to $39 \mathrm{Ma}$ as calibrated by magnetostratigraphy at Site 689 . This would suggest that Sample 113-696B-62R-6, 130-132 cm, is about $39 \mathrm{Ma}$ 


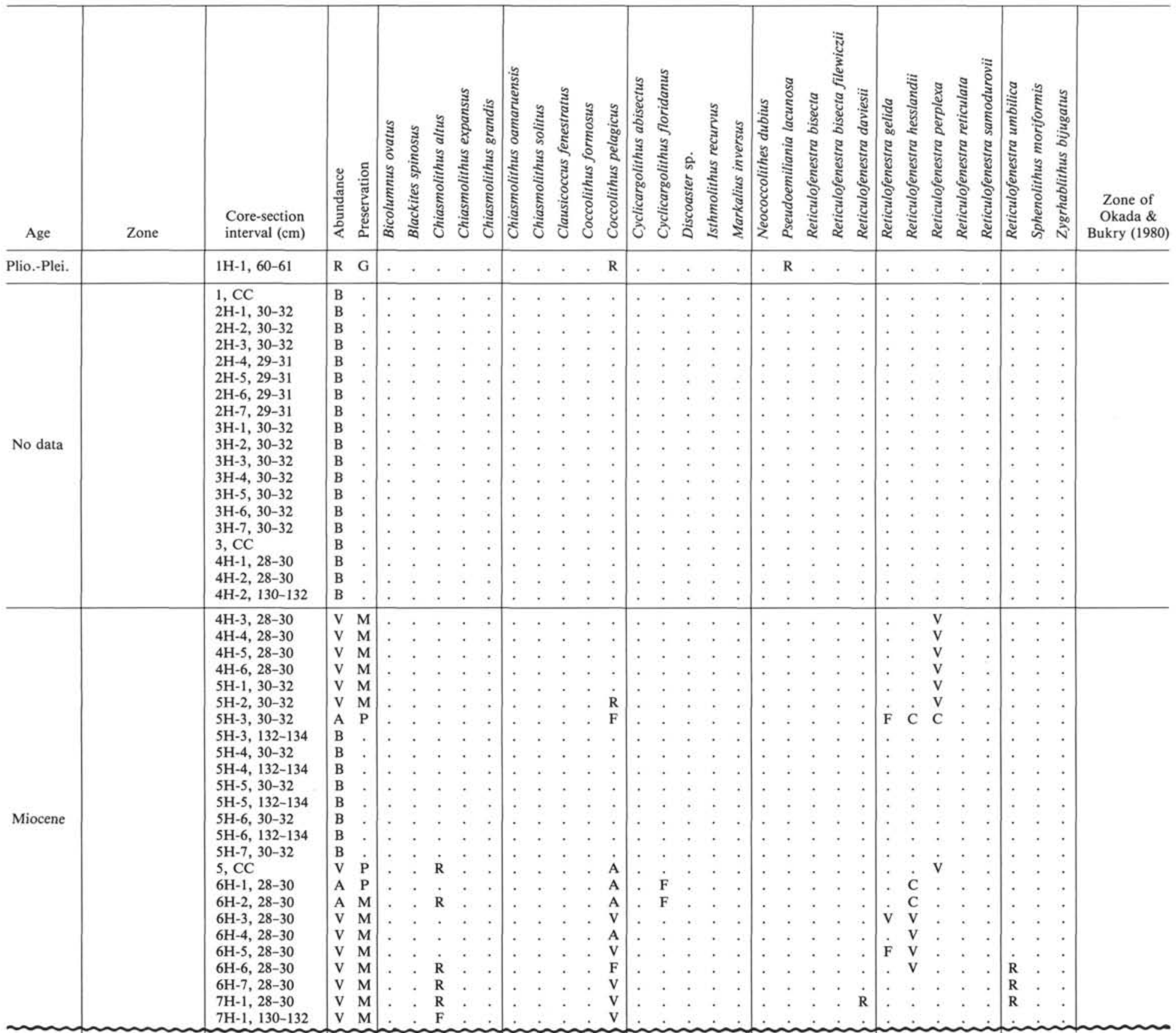




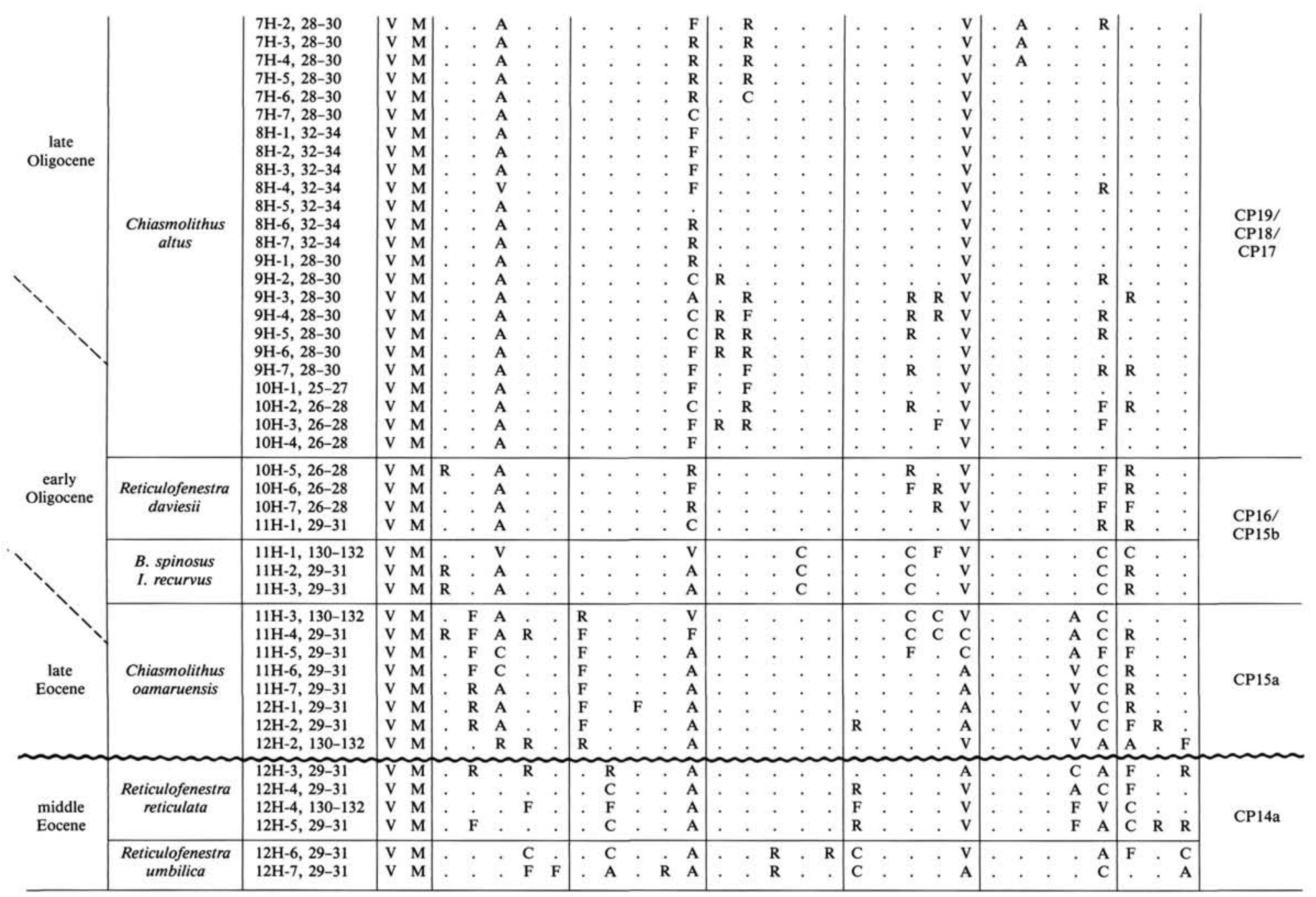


Table 3. Distribution of late Oligocene calcareous nannofossils, ODP Hole 693A.

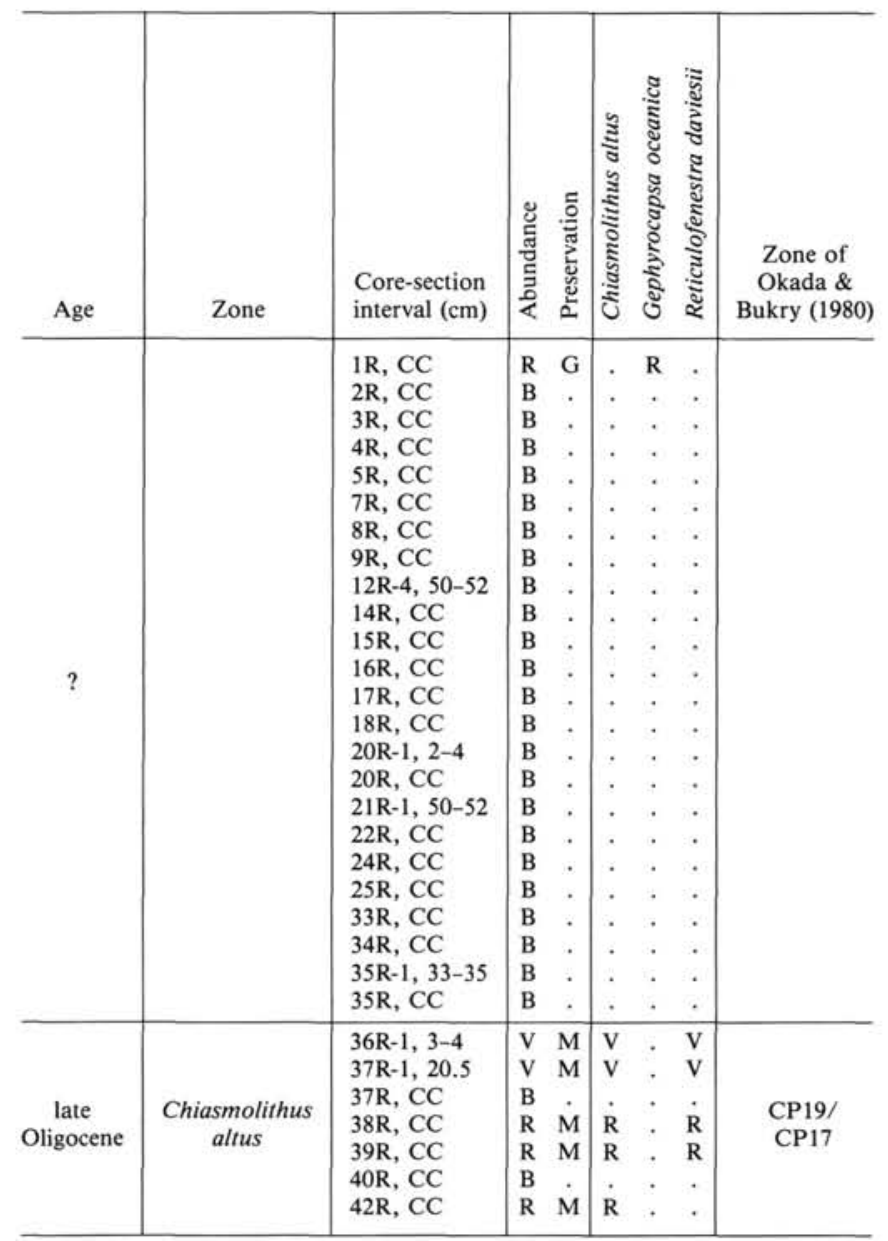

Note: Occurrence: $\mathrm{V}=$ very abundant; $\mathrm{A}=$ abundant; $\mathrm{C}=$ common; $\mathrm{F}=$ few; $\mathrm{R}=$ rare; $\mathrm{B}=$ barren. Preservation: $\mathrm{P}=$ poor $\mathrm{M}=$ moderate.

in age. This age information is significant for this otherwise poorly dated interval. A palynoflora that includes Nothofagus pollen and fern spores (genera Laerigalosporites and Polypodraceoisporites; Barker, Kennett, et al., 1988) has been found in several samples in the same core. These spores and pollen indicate that a temperate beech forest with an undergrowth of ferns existed under frost-free conditions on West Antarctica during the latest Eocene (as dated by calcareous nannofossils).

\section{GRAPHIC CORRELATION OF HOLES 689B AND 690B}

Graphic correlation was first proposed by Shaw (1964) and has subsequently been used profitably by micropaleontologists and by others (e.g., Prell et al., 1986; Dowsett, 1988; Hazel, 1988). This method was applied to sections from Holes 689B and 690B to identify hiatuses, to examine sediment accumulation history, and to evaluate the accuracy of the calcareous nannofossil datums determined and the degree of synchroneity of these datums. We plotted the datums in Figure 5 using the subbottom depth of Hole 689B as the vertical axis and that of Hole $690 \mathrm{~B}$ as the horizontal axis. Two lines were drawn that best fit the data points, and these two lines indicate the true correlation between Holes 689B and 690B.

Note that if the data points fall on a straight line, then all of the following four requirements are met: (1) consistent determi-
Table 4. Distribution of late Oligocene-Miocene calcareous nannofossils, ODP Hole 693B.

\begin{tabular}{|c|c|c|c|c|c|c|c|}
\hline Age & Zone & $\begin{array}{l}\text { Core-section } \\
\text { interval }(\mathrm{cm})\end{array}$ & 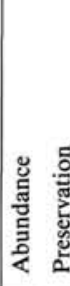 & & 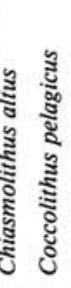 & 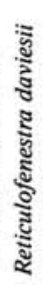 & $\begin{array}{c}\text { Zone of } \\
\text { Okada \& } \\
\text { Bukry, } 1980\end{array}$ \\
\hline ? & & $\begin{array}{l}6 \mathrm{H}-4,56-58 \\
8 \mathrm{X}, \mathrm{CC} \\
9 \mathrm{X}, \mathrm{CC} \\
10 \mathrm{X}, \mathrm{CC} \\
11 \mathrm{X}, \mathrm{CC}\end{array}$ & $\begin{array}{ll}\text { A } & \text { P } \\
\text { B } & \text {. } \\
\text { B } & \text {. } \\
\text { B } & \text { B } \\
\text { B } & \text {. }\end{array}$ & & 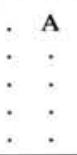 & & \\
\hline $\begin{array}{c}\text { late } \\
\text { Oligocene }\end{array}$ & $\begin{array}{c}\text { Chiasmolithus } \\
\text { altus }\end{array}$ & $\begin{array}{l}12 X-2,122 \\
12 X-3,39 \\
13 X-3,6\end{array}$ & $\begin{array}{ll}\mathrm{V} & \mathrm{M} \\
\mathrm{V} & \mathrm{M} \\
\mathrm{V} & \mathrm{M}\end{array}$ & & $\begin{array}{ll}\mathrm{V} & . \\
\mathrm{V} & \dot{\mathrm{R}} \\
\mathrm{A} & .\end{array}$ & & $\begin{array}{l}\text { CP19/ } \\
\text { CP17 }\end{array}$ \\
\hline$?$ & & $\begin{array}{l}16 \mathrm{X}-1,120-122 \\
16 \mathrm{X}-2,30-32 \\
16 \mathrm{X}-3,30-32 \\
17 \mathrm{X}-1,30-32 \\
17 \mathrm{X}-1,122-124 \\
17 \mathrm{X}-2,30-32 \\
18 \mathrm{X}-1,29-31 \\
18 \mathrm{X}-2,124-126 \\
18 \mathrm{X}-3,52-54 \\
18 \mathrm{X}-4,46-48 \\
18 \mathrm{X}-5,109-111 \\
19 \mathrm{X}-1,30-32 \\
19 \mathrm{X}-1,128-130 \\
19 \mathrm{X}-2,45-47\end{array}$ & $\begin{array}{l:}\text { B } \\
\text { B } \\
\text { B } \\
\text { B } \\
\text { B } \\
\text { B } \\
\text { B } \\
\text { B } \\
\text { B } \\
\text { B } \\
\text { B } \\
\text { B } \\
\text { B } \\
\text { B }\end{array}$ & & 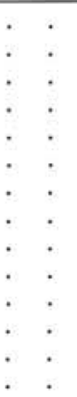 & & \\
\hline
\end{tabular}

Note: Occurrence: $\mathrm{V}=$ very abundant $\mathrm{A}=$ abundant; $\mathrm{C}=$ common; $\mathrm{F}=$ few; $\mathrm{R}$ $=$ rare; $\mathrm{B}=$ barren. Preservation: $\mathrm{P}=$ poor $\mathrm{M}=$ moderate.

nation of all the datums at both sites; (2) synchroneity of the datums; (3) constant ratio of sedimentation rates between the two sites; (4) any hiatuses that exist are synchronous at both sites. If any of these four requirements are not fulfilled, the data points will fall off the straight line.

The apparent separation of the two lines of correlation between 90.4 and 92.4 mbsf in Hole 690B indicates a hiatus which cannot be observed in Hole 689B. This supports the biostratigraphic results discussed above. Judging from the graphic correlation diagram, $5-10 \mathrm{~m}$ of sediment are missing at that depth in Hole 690B.

The good fit of the data points (especially 1 through 5) on the two lines makes us more confident that we have correlated the two sites correctly, and enables us to draw the following conclusions: (1) the 10 calcareous nannofossil datums have been consistently identified and located in both holes; (2) the datums are synchronous at these two sites; (3) except for the hiatus just mentioned in Hole 690B, the sedimentary history is similar at both sites; between 92 and 105 mbsf at Site 690, the sedimentation rate is 0.4 of that for the equivalent section at Site 689 (131-159 mbsf), and the ratio of sedimentation rates is relatively constant at 0.83 for the upper part of Hole 690B versus that of Hole 689B; (4) except for the hiatus around 91 mbsf at Site 690, all of the hiatuses, including the one already identified at the Oligocene/Miocene boundary and those not identified, are geologically synchronous at both sites.

\section{CORRELATION OF NANNOFOSSIL DATUMS WITH MAGNETOSTRATIGRAPHY}

As mentioned previously, the middle Eocene through the Pleistocene sections in Holes 689B and 690B were taken by HPC with nearly $100 \%$ core recovery. The extremely abundant 
Table 5. Distribution of late Eocene to Miocene calcareous nannofossils, ODP Hole 696B.

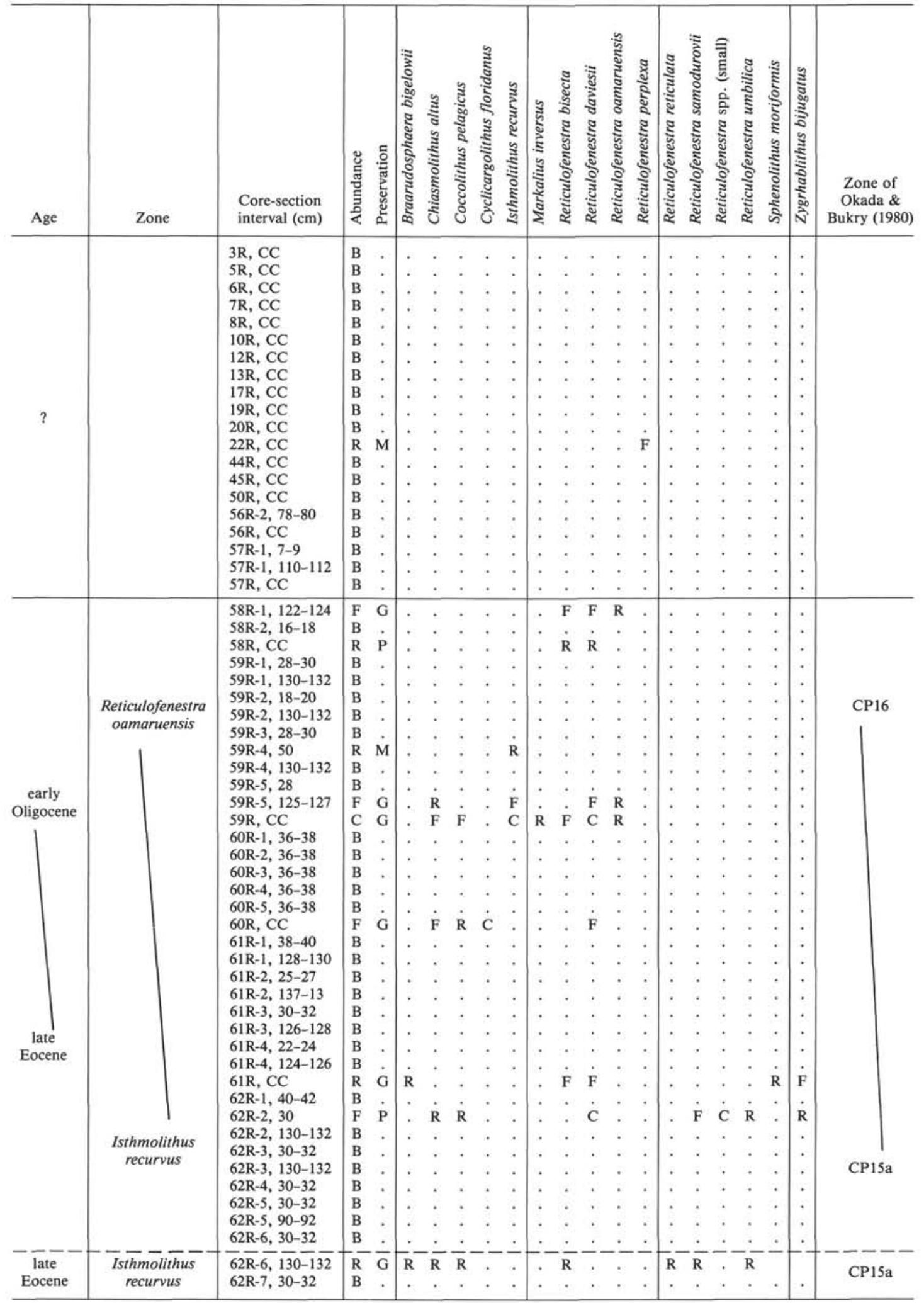

Note: Occurrence: $\mathrm{V}=$ very abundant $\mathrm{A}=$ abundant $\mathrm{C}=$ common; $\mathrm{F}=$ few $; \mathrm{R}=$ rare; $\mathrm{B}=$ barren. Preservation: $\mathrm{P}=$ poor $; \mathrm{M}=$ moderate. 


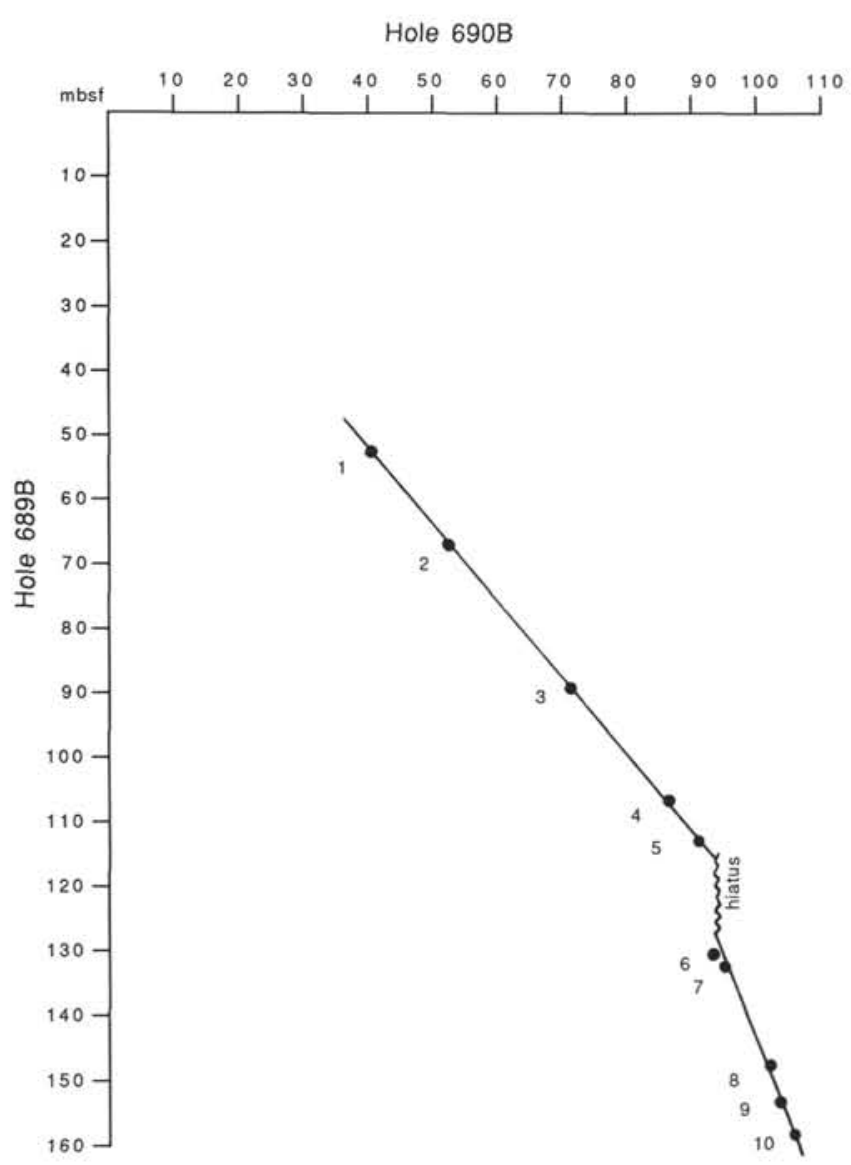

Figure 5. Graphic correlation of ODP Holes 689B and 690B. $1=$ FO of Reticulofenestra perplexa; 2 = last common Chiasmolithus altus; $3=$ abrupt decrease in abundance of Coccolithus pelagicus; $4=\mathrm{LO}$ of $\mathrm{Re}$ ticulofenestra umbilica; $5=\mathrm{LO}$ of Isthmolithus recurvus; $6=$ FO of Isthmolithus recurvus; $7=\mathrm{LO}$ of Reticulofenestra reticulata; $8=\mathrm{FO}$ of Chiasmolithus oamaruensis; 9 = LO of Chiasmolithus solitus; $10=$ FO of $R$. reticulata.

microfossils (siliceous microfossils dominate the Neogene sequence and calcareous microfossils dominate the Paleogene sequence) in the sections provide good biostratigraphic control, and the magnetostratigaphy (V. Spieß, written comm., 1989) is excellent, especially for Hole 689B. This offers, for the first time, an excellent opportunity to correlate biostratigaphy with magnetostratigraphy in the extreme southern high-latitudes. This considerably extends the geographic limits of other such correlations we have carried out in the South Atlantic Basin (Wei and Wise, 1989).

In this study we correlate the nannofossil datums of Sites 689 and 690 to the magnetostratigraphy of V. Spieß (written comm., 1989). We interpret the intervals of magnetic normal in Cores $113-690 \mathrm{~B}-9 \mathrm{H}$, and $-10 \mathrm{H}$ as $\mathrm{C} 11 \mathrm{~N}$ and $\mathrm{C} 12 \mathrm{~N}$ respectively instead of $\mathrm{C} 10 \mathrm{~N}$ and $\mathrm{C} 11 \mathrm{~N}$ given by Spieß. Our interpretation is based on the last occurrence of Reticulofenestra umbilica in the lower part of Core 113-690B-10H and the last occurrence of Isthmolithus recurvus near the top of Core 113-690B-11H. These two datums have been found consistently within C12R at Site 689 and in many mid-latitude areas (Wei and Wise, 1989). It is unlikely that both these datums are diachronous by one magnetic chron between Sites 689 and 690 . In the following discussion, we use the magnetic polarity time-scale of Berggren et al. (1985), which has been widely used in many studies. This would facili- tate comparison among different studies. When assigning an age for each datum in Holes 689B and 690B, we assume uniform sediment accumulation in the magnetic subchron where the datum is located. This assumption may not hold true in all cases, but the relatively large number of polarity reversals in the upper Paleogene generally enables the placement of the datums within an accuracy of 0.1-0.6 m.y.

Figure 6 shows the correlation of the LO of Reticulofenestra umbilica with magnetostratigaphy at Sites 689 and 690 on Maud Rise, Sites 516, 522, 523, and 528 in the middle-latitude South Atlantic, and Sites 558 and 563 in the North Atlantic. This datum falls within Subchron C12R at all the sites but at different levels. Results from Sites 689 and 690 (33.2 Ma) agree quite well with those from Site 528. Ages at other sites are older by about $1.2 \mathrm{~m}$.y. If the LO of $R$. umbilica is used as a datum, it is important that a consistent species concept be applied, because there is a rather gradual change in mean size through time in the Reticulofenestra samodurovii $(=R$. dictyoda or $R$. coenura of some authors)- $R$. umbilica lineage (Backman and Hermelin, 1986). In this study we use $14 \mu \mathrm{m}$ as the cutoff between the two species.

It should also be noted that Reticulofenestra umbilica is mostly rare at Sites 689 and 690 after about $38 \mathrm{Ma}$, in contrast to its general abundance in the middle latitudes. This does not support the suggestion that $R$. umbilica is a cold water species, but suggests a preference for more temperate waters. It is apparent that when the water temperature dropped near the Eocene/ Oligocene boundary and these high latitudes became permanently cool, $R$. umbilica did not thrive in this area but became a transient species.

The LO of Isthmolithus recurvus at both Sites 689 and 690 (34.8 Ma) agrees well with those found in the middle-latitude South Atlantic, the North Atlantic, and the Contessa area in Italy (Fig. 7). This datum was applied by Wise (1983) as a provincial zonal marker in the Oligocene sediment from the Falkland Plateau region. The species is usually rare or absent in low-latitude areas (Bukry, 1978), more abundant in middle- and high-

\section{LO Reticulofenestra umbilica}

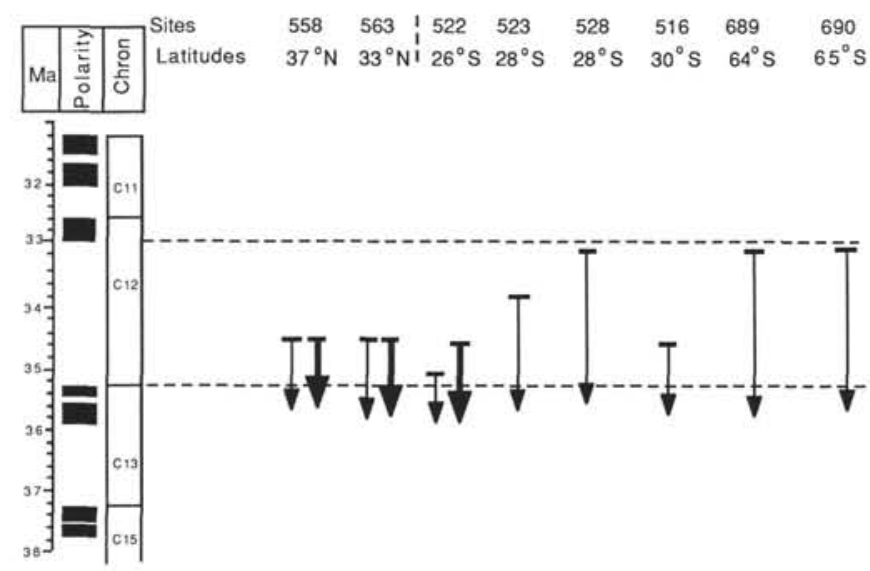

Figure 6. Correlation of the LO of Reticulofenestra umbilica with the magnetic time-scale of Berggren et al. (1985). Data are taken from: Site 558, Miller et al. (1985) in thinner line and Parker et al. (1985) in thicker line; Site 563, Miller et al. (1985) in thinner line and Parker et al. (1985) in thicker line; Site 522, Backman (1987) in thinner line and Poore et al. (1984) in thicker line; Site 523, Backman (1987); Site 528, Shackleton et al. (1984); Site 516, Wei and Wise (1989); Sites 689 and 690, this study. 


\section{FO and LO Isthmolithus recurvus}

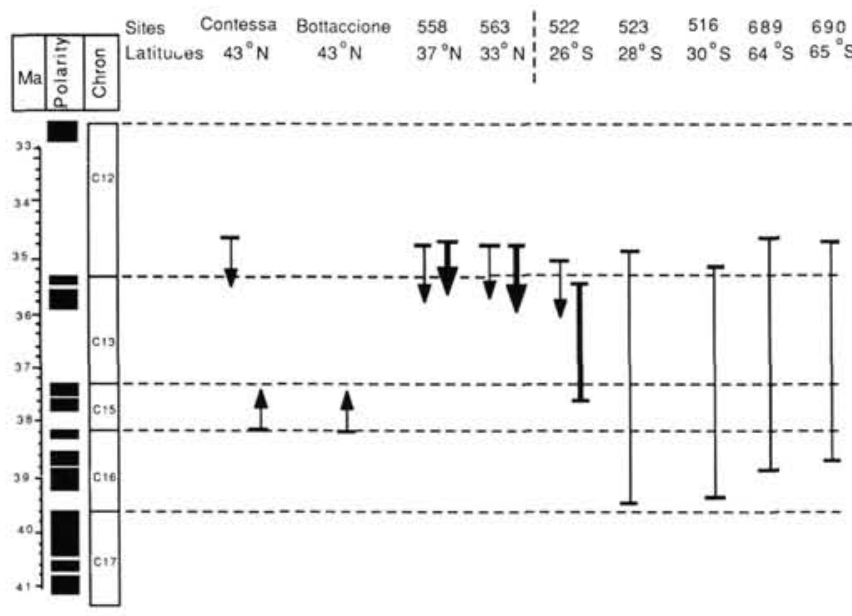

Figure 7. Correlation of the $\mathrm{FO}$ and $\mathrm{LO}$ of Isthmolithus recurvus with the magnetic time-scale of Berggren et al. (1985). Data are taken from: Contessa Section, FO-Monechi and Thierstein (1985), LO-Lowrie et al. (1982); Bottaccione Section, Monechi and Thierstein (1985); Sites 558 and 563, Miller et al. (1985) in thinner line and Parker et al. (1985) in thicker line; Site 522, Backman (1987) in thinner line and Poore et al. (1984) in thicker line; Site 523, Backman (1987); Site 516, Wei and Wise (1989); Sites 689 and 690, this study.

latitudes, and has been found to be common in the southernmost marine sequence recovered to date $\left(77^{\circ} \mathrm{S}\right.$ in the Ross Sea: Edwards and Waghorn, 1989; Wei, in prep.). The association of this species with cool or cold waters has led some workers to believe that $I$. recurvus is a paleoenvironmental indicator rather than a precise biostratigraphic marker (Backman, 1987). However, the currently available magnetostratigraphic data from a number of sites in the middle- and high-latitudes (Fig. 7) reveal clearly that the LO of I. recurvus is one of those few datums that promise relatively precise biostratigraphic correlation among middle- and high-latitude sites.

The assigned ages for the FO of Isthmolithus recurvus at Sites 689 and 690 are 38.8 and 38.6 Ma respectively (Fig. 7), a rather good agreement considering some uncertainties in the sediment accumulation rates. Results from other sites show less consistent ages: Percival (1984) reported that I. recurvus first occurs close to the bottom of Hole 522A (middle-latitude South Atlantic) at about $37.8 \mathrm{Ma}$ based on correlation with magnetostratigraphy and using the time scale of Berggren et al. (1985). Backman (1987) found rare specimens of $I$. recurvus sporadically down to the bottom of Chron $\mathrm{C} 16$ at Site 523 which is close to Site 522, and gave an age of $39.5 \mathrm{Ma}$ for the FO of $I$. recurvus; this age coincides with that at Sites 516 (southwestern Atlantic). In the Contessa and Bottaccione sections, Monechi and Thierstein (1985) located the FO of $I$. recurvus near the top of Chron $\mathrm{C} 16$ at about $38.2 \mathrm{Ma}$. The largest age difference for the FO of $I$. recurvus from these sites is $1.7 \mathrm{~m}$.y. Berggren et al. (1985) took the minimal age $(37.8 \mathrm{Ma})$ from Site 522 , which is clearly unrepresentative. It is also interesting to note that the FO of $I$. recurvus appears to be younger toward higher latitudes though data are insufficient for unequivocal interpretation. This trend is opposite to what is expected based on the association of this species with cool and cold waters.

As mentioned previously, the LO of Reticulofenestra oamaruensis has been found consistently below the LO of Isthmolithus recurvus in the Falkland Plateau region (Wise, 1983), in the southwest Pacific (Martini, 1986), and on Maud Rise. It is, therefore, used in this study as a datum in the lower Oligocene sequence. The FO of $R$. oamaruensis has also been used by a number of authors in high-latitude zonations (Edwards, 1971; Edwards and Perch-Nielsen, 1975; Wise, 1988). Figure 8 shows the correlation of the FO and LO of $R$. oamaruensis with the magnetostratigraphy at Site 689; its FO and LO are dated at about 38.0 and 36.0 Ma respectively. A major hiatus at Site 690 eliminates the presence of the species there.

Reticulofenestra reticulata has been reported from a variety of environments ranging from neritic to oceanic settings and from low to high latitudes (Perch-Nielsen, 1986). The LO of $R$. reticulata has been consistently found slightly below the LO of Discoaster saipanensis in different regions around the world; therefore, a number of authors have suggested using the LO of $R$. reticulata as a datum level near the top of the Eocene (Müller, 1970, 1979; Shafik, 1981; Martini and Müller, 1986). The overlap in the range of $R$. reticulata with that of Isthmolithus recurvus is also well recognized in many regions (Perch-Nielsen, 1986) including the Falkland Plateau (Wise, 1983). However, the ranges of Reticulofenestra reticulata and $I$. recurvus do not overlap at Sites 689 and 690 . It was initially thought that a hiatus might account for this. Correlation of the total biostratigraphic range of $R$. reticulata with magnetostratigaphy (Fig. 9) dates the LO of the species at about $38.9 \mathrm{Ma}$ at Sites 689 and $690,1.3 \mathrm{~m} . \mathrm{y}$. older than that found at the middle-latitude Sites 516 and 522 (South Atlantic). The earlier extinction of $R$. reticulata in the higher latitude eliminates the range overlap of $R$. reticulata and $I$. recurvus. Correlation with magnetostratigaphy also dates the FO of $R$. reticulata at about $42.1 \mathrm{Ma}$ at Sites 689 and 690 , or $1.6 \mathrm{~m} . \mathrm{y}$. younger than that at Site 516 .

Reticulofenestra reticulata was believed by Bukry (1977) to be a tropical or warm-water species based on its common occurrences in Zone CP15 at Site 366 in the eastern equatorial Atlantic. Aubry (1983) also classified it as a warm-water species. However, abundant $R$. reticulata have been found at the middlelatitude Site 516 (Wei and Wise, 1989) as well as in the extreme high-latitude Sites 689 and 690 (Tables 1 and 2) from the upper

\section{FO and LO Reticulofenestra oamaruensis}

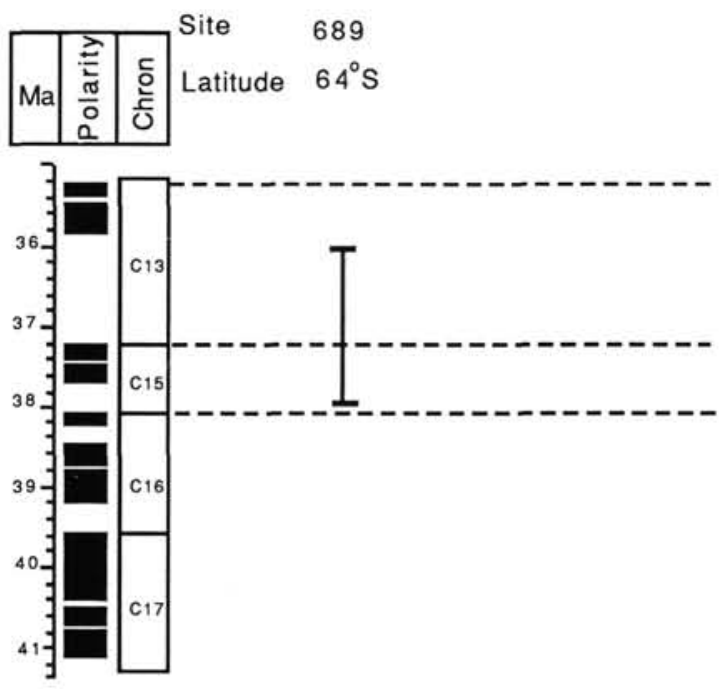

Figure 8. Correlation of the FO and LO of Reticulofenestra oamaruensis with the magnetic time-scale of Berggren et al. (1985). Data are taken from this study. 
FO and LO Reticulofenestra reticulata

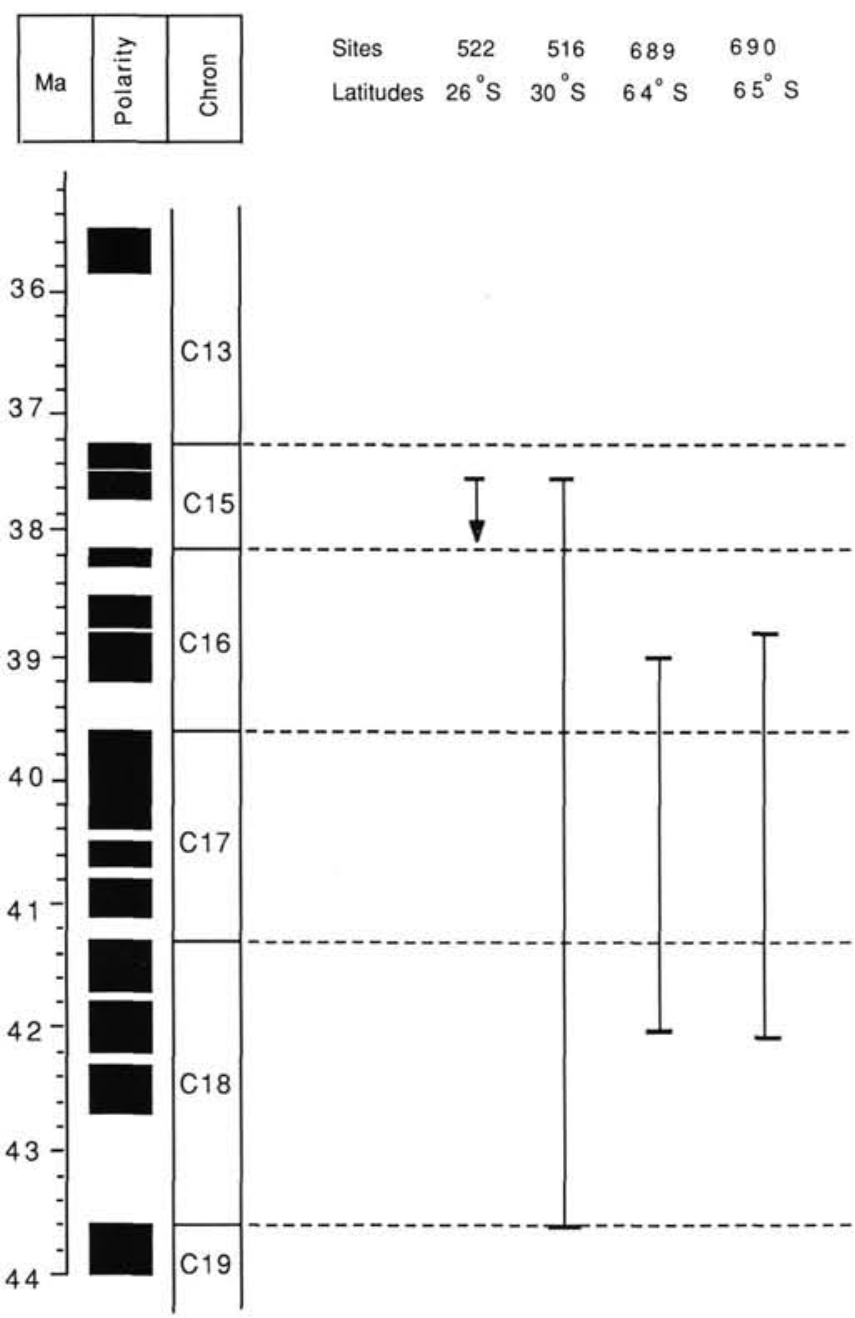

Figure 9. Correlation of the FO and LO of Reticulofenestra reticulata with the magnetic time-scale of Berggren et al. (1985). Data are taken from: Site 522, Backman (1987); Site 516, Wei and Wise (1989); Sites 689 and 690 , this study.

middle Eocene to the upper Eocene section. The relative abundance in these middle and high-latitude sites is even greater than that at the equatorial Site 366 . This contradicts the notion that $R$. reticulata preferred tropical waters. On the other hand, this species is common in a very short interval $(0.1 \mathrm{~m}$.y. according to the magnetostratigraphy) at Site 522 in the middle-latitude South Atlantic, and is very rare outside this interval. The upper Eocene section at Site 511 at $51^{\circ} \mathrm{S}$ in the South Atlantic yielded only few $R$. reticulata. Although the reason for the irregular abundance pattern in different regions is not apparent at this time, it is clear that $R$. reticulata is not latitudinally limited and should not be classified as a warm-water species.

Correlation of the LO of Chiasmolithus oamaruensis with magnetostratigraphy indicates that this datum is located considerably higher at Site $689(36.5 \mathrm{Ma})$ than in the middle-latitudes (Fig. 10). The LO of C. oamaruensis at Site 690 could not be determined due to a major hiatus. It appears from Figure 10 that this species occurs earlier and become extinct later in the high latitudes. This time transgression is not surprising since $C$. oamaruensis is known to prefer cooler waters. The age of the
FO and LO Chiasmolithus

oamaruensis
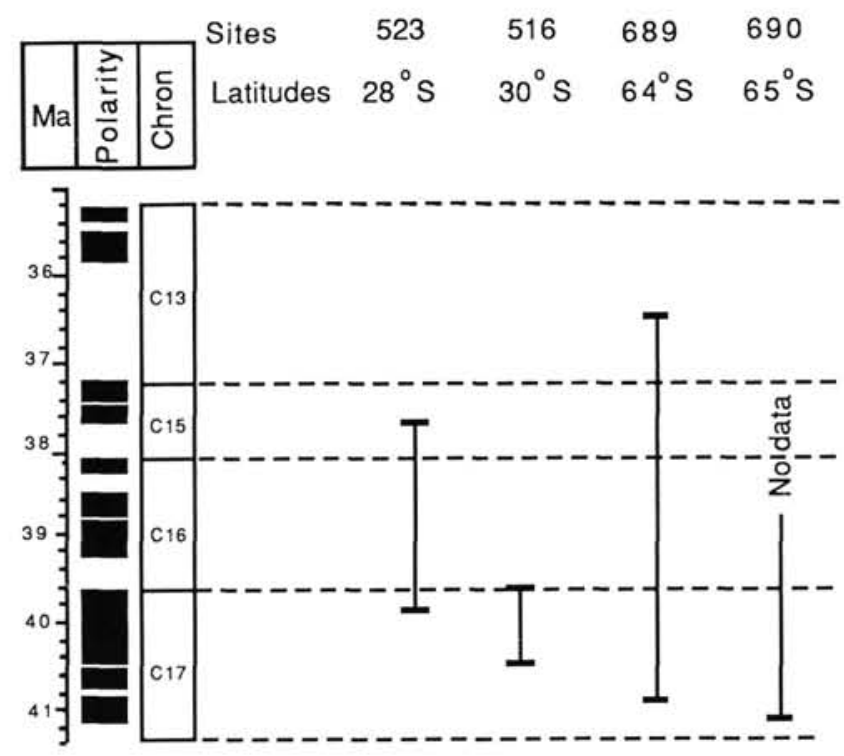

Figure 10. Correlation of the FO and LO of Chiasmolithus oamaruensis with the magnetic time-scale of Berggren et al. (1985). Data are taken from: Site 523, Poore et al. (1984); Site 516, Wei and Wise (1989); Sites 689 and 690 , this study.

FO of C. oamaruensis in the time scale of Berggren et al. (1985) was based on the correlation at Site 523, but it is now clear that this age is not applicable at higher latitudes.

The LO of Chiasmolithus solitus was used as a marker in the late middle Eocene in the zonations of Martini (1971) and Okada and Bukry (1980). Wise and Mostajo (1983) found an exceptionally high sedimentation rate $(70 \mathrm{~m} / \mathrm{m} . \mathrm{y}$.) using the ages of the LO of C. solitus and the FO of Reticulofenestra umbilica of Bukry (1973) for Subzone CP14a at Maurice Ewing Bank (Falkland Plateau, South Atlantic); they suspected that C. solitus persisted longer in the higher latitudes than in the tropics. Wei and Wise (1989) compared the biomagnetostratigraphic results of Site 516 with that of Site 523 and found that $C$. solitus disappeared earlier at the latter site than at the higher latitude Site 516. They concluded that the LO of $C$. solitus is time-transgressive over different latitudes. The present study indicates that the datum is about $41.4 \mathrm{Ma}$ at both Sites 689 and 690 , in remarkable agreement with that at Site 516 (Fig. 11). The only difference is that $C$. solitus is mostly common up to its extinction at the high-latitude sites whereas it is rare near its extinction at the middle-latitude Site 516. Figure 11 appears to suggest that between $30^{\circ}$ and $65^{\circ} \mathrm{S}$ in the Atlantic, the LO of C. solitus is geologically synchronous; north of $30^{\circ} \mathrm{S}$, the datum is time-transgressive, getting older toward lower latitudes where the species becomes generally rare or absent in tropical areas. This diminution in abundance toward the tropics is characteristic of chiasmoliths as a group, because they prefer temperate and cold waters (Bukry, 1973).

\section{PALEOBIOGEOGRAPHY OF SELECTED SPECIES}

Cenozoic calcareous nannofossil paleobiogeography has been discussed by Haq and Lohmann (1976), Haq, Lohmann, and Wise (1977), Haq, Perch-Nielsen, and Lohmann (1977), Haq (1980). Data from south of $52^{\circ} \mathrm{S}$ were unavailable to them, and some of their conclusions need to be revised in view of the new data from the recent drilling in the high latitudes. 
In the following discussion of calcareous nannofossil paleobiogeography, particular attention is paid to information from: Site 516 in the middle-latitude South Atlantic $\left(30^{\circ} \mathrm{S}\right)$, the highlatitude Sites $511\left(51^{\circ} \mathrm{S}\right), 512\left(50^{\circ} \mathrm{S}\right)$, and $513\left(47^{\circ} \mathrm{S}\right)$ in the vicinity of Falkland Plateau, and the southernmost Sites $689\left(64^{\circ} \mathrm{S}\right)$ and $690\left(65^{\circ} \mathrm{S}\right)$ on Maud Rise. We have examined material from all these sites and thus maintained a consistent species concept, which facilitates comparison of species abundances among different sites to reveal paleobiogeographic patterns.

Middle Miocene sediments at Sites 689 and 690 yielded practically monospecific assemblages of Reticulofenestra perplexa. This species was first described by Burns (1975) from Antarctic sediments and has subsequently been reported to be abundant in the high-latitude South Atlantic by Haq, Lohmann, and Wise (1977) and in the high-latitude North Atlantic by Backman (1980), where they referred to it as "Dictyoccites antarcticus " (a junior synonym of $R$. perplexa; see Wise, 1983, p. 505). The species has never been reported from the middle or low latitudes and is apparently a cold water species.

Helicosphaera has not been observed in Leg 113 material. Only one species of Helicososphaera (H. carteri) was found in upper Quaternary sediments in the Falkland Plateau (Wise, 1983). However, numerous species of Helicosphaera were reported from the middle to low latitude sediments in the South Atlantic (Perch-Nielsen, 1977). It can be concluded that species of Helicosphaera are warm water forms and are generally limited to latitudes lower than about $50^{\circ} \mathrm{S}$ from late Eocene through Pliocene times.

The LO of Cyclicargolithus floridanus has been used as a substitute marker for the $\mathrm{CN} 5 \mathrm{a} / \mathrm{CN} 5$ b boundary by Okada and

\section{LO Chiasmolithus solitus}

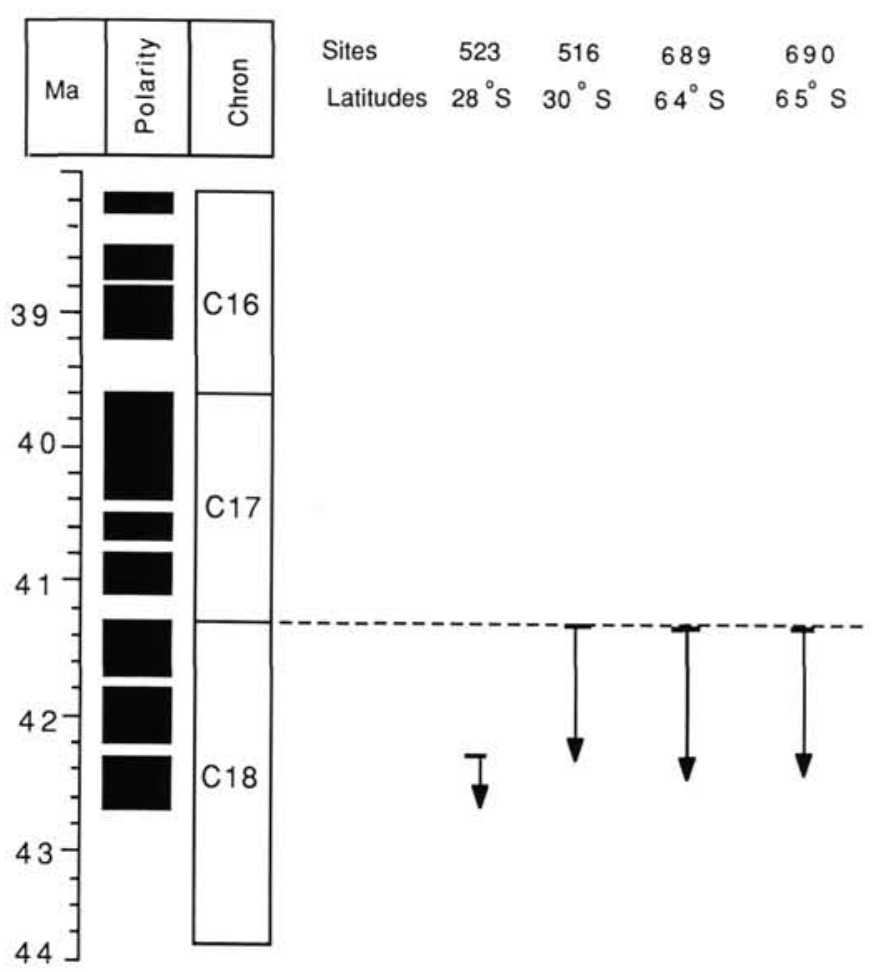

Figure 11. Correlation of the LO of Chiasmolithus solitus with the magnetic time-scale of Berggren et al. (1985). Data are taken from: Site 523, Poore et al. (1984); Site 516, Wei and Wise (1989); Sites 689 and 690, this study.
Bukry (1980). This species is abundant at Sites 516 and 513 (Fig. 12 ), but its relative abundance decreases drastically toward the higher latitude Site 511 . Sites 689 and 690 only contain sporadic C. floridanus in the upper Oligocene. It is readily apparent from Figure 6 that $C$. floridanus did not thrive outside warm or temperate waters and cannot be used as a marker at high latitudes.

The LO of Reticulofenestra bisecta is a substitute marker for the top of CP19 in Okada and Bukry's (1980) low latitude zonation and a zonal marker in the upper Oligocene in the zonations of Edwards (1971), Wise (1983), and Waghorn (in Perch-Nielsen, 1985). Various authors have proposed this datum to mark the Paleogene/Neogene boundary (see Biolzi, 1985; Berggren et al., 1985 for detailed discussions). From the distribution pattern of $R$. bisecta in a latitudinal transect in the South Atlantic (Fig.

\section{Cyclicargolithus floridanus}

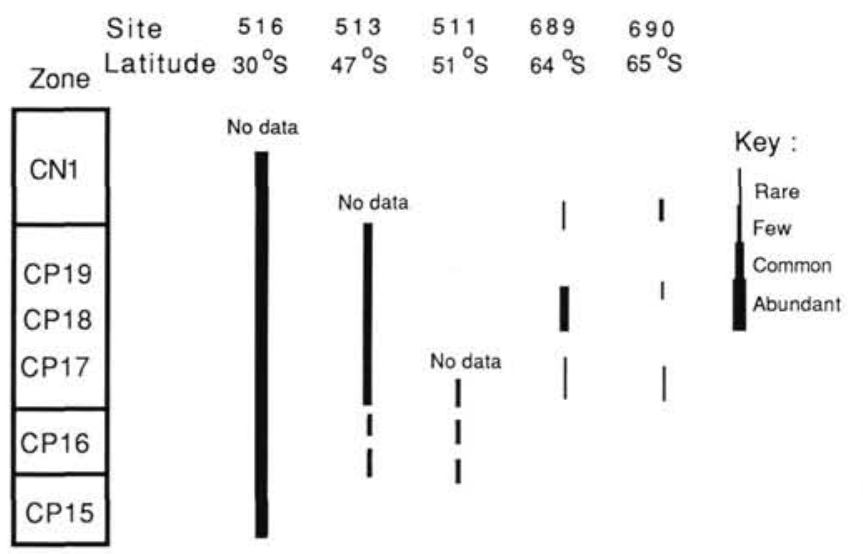

Figure 12. Simplified distribution patterns of Cyclicargolithus floridanus. Data are taken from: Wise (1983) for Sites 511 and 513; Wei and Wise (1989) for Site 516; the present study for Sites 689 and 690.

13), it can be seen that this species is abundant to common at Sites 516 from the middle Eocene through Oligocene. However, it is common only in the upper Eocene and lowermost lower Oligocene at the higher latitude Sites 689 and 690, and rare and sporadic in the younger sediments at the latter two sites. The last occurrence of $R$. bisecta at Site 690 is considerably lower (in the lower Oligocene) than at the lower-latitude sites. On the other hand, tropical sediments also contain reduced numbers of $R$. bisecta (Roth and Thierstein, 1972; Perch-Nielsen, 1977). It is clear now that $R$. bisecta, a species grouped into the high-latitude assemblage by Haq and Lohmann (1976), is more of a temperate-water species which did not thrive at the highest latitudes. The LO of $R$. bisecta can be used readily to approximate the Oligocene/Miocene boundary only in middle-latitude sediments, and is unreliable in the very high latitudes.

Unlike Reticulofenestra bisecta, Chiasmolithus altus is most abundant in the highest latitude Site 690 , and it decreases in abundance toward lower latitudes (Fig. 13). It is thus clear that C. altus is a cool-cold water species. Accordingly, its first occurrence is earlier in the high latitudes (late middle Eocene) than in the middle-latitude Site 516 (Fig. 13). The time transgression of the last occurrence of $C$. altus with latitude is expected, but cannot be shown here due to hiatuses at the high-latitude Sites 511, 689 , and 690 . 


\section{Reticulofenestra bisecta Chiasmolithus altus}

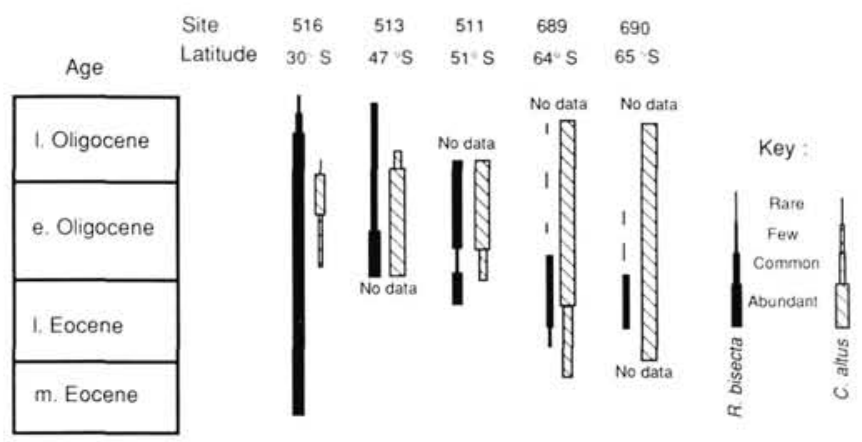

Figure 13. Simplified distribution patterns of Reticulofenestra bisecta and Chiasmolithus altus through time in a latitudinal transect. Data are taken from: Wise (1983) for Sites 511 and 513; Wei and Wise (1989) for Site 516; the present study for Sites 689 and 690.

Clausicoccus fenestratus is also an important species because the top of its acme defines the top of CP16a in Okada and Bukry's (1980) zonation (their Coccolithus subdistichus $=$ Clausicoccus fenestratus), and the LO of $C$. fenestratus has been used as a provincial zonal marker for the lower Oligocene sediment in Wise's (1983) zonation. Figure 14 clearly demonstrates that in the South Atlantic the range of $C$. fenestratus is longest at Site 516 (middle Eocene through Oligocene) and becomes progressively shorter toward the higher latitudes. Common or abundant $C$. fenestratus were found only in the lower Oligocene sediments at Sites 516, 513, and 511. Sites 689 and 690 only yielded rare to few $C$. fenestratus in a few samples in the upper Eocene. We conclude that the occurrence of $C$. fenestratus is strongly influenced by water temperature and that the datum is time transgressive with latitude.

Coccolithus formosus, the $\mathrm{LO}$ of which has been widely used to mark the CP16b/CP16c (NP21/NP22) boundary, is very distinct and can be identified even in poorly preserved assemblages (Wise, 1973). Wei and Wise (1989) have shown that the LO of C. formosus is geologically synchronous in the middle latitudes and is an excellent marker for the low- and middle-latitude sediments. This datum is, however, not applicable in the high latitudes, because rare $C$. formosus were found only in one sample each at Sites 689 and 690 from the upper middle Eocene and younger sediments. At Site 511 it is rare toward the top of its range in the lower Oligocene (Wise, 1983). Figure 15 shows that C. formosus decreases in abundance toward higher latitudes, and that it became extinct considerably earlier at Sites 689 and 690 than those in the lower latitudes. It is apparent that $C$. formosus is a warm-water species. This result contradicts Haq and Lohmann's (1976) conclusion that $C$. formosus belongs to highlatitude assemblages.

\section{SOME PALEOCEANOGRAPHIC INFERENCES}

Discoasters, recognized as warm-water indicators (Bukry, 1973, 1978; Siesser, 1984), are absent in the upper middle Eocene to upper Eocene sediments at Sites 689 and 690. However, discoasters are still few to common in age-equivalent sediments in the lower latitude Sites 511 and 512 in the Falkland Plateau region. In addition, as noted above, Coccolithus formosus is virtually missing in the upper middle Eocene and younger sediments at Sites 689 and 690 , whereas the species is few to common in the and is an excellent marker for the low- and middle-latitude sediments. This datum is, however, not applicable in the high latitudes, because rare $C$. formosus were found only in one sample

\section{Clausicoccus fenestratus}

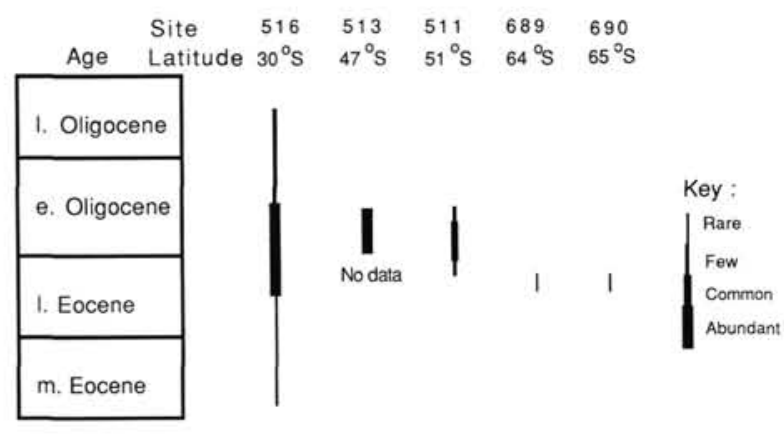

Figure 14. Simplified distribution patterns of Clausicoccus fenestratus through time in a latitudinal transect. Data are taken from: Wise (1983) for Sites 511 and 513; Wei and Wise (1989) for Site 516; the present study for Sites 689 and 690 .

each at Sites 689 and 690 from the upper middle Eocene and younger sediments. At Site 511 it is rare toward the top of its range in the lower Oligocene (Wise, 1983). Figure 15 shows that C. formosus decreases in abundance toward higher latitudes, and that it became extinct considerably earlier at Sites 689 and 690 than those in the lower latitudes. It is apparent that $C$. formosus is a warm-water species. This result contradicts Haq and Lohmann's (1976) conclusion that $C$. formosus belongs to highlatitude assemblages.

\section{SOME PALEOCEANOGRAPHIC INFERENCES}

Discoasters, recognized as warm-water indicators (Bukry, 1973, 1978; Siesser, 1984), are absent in the upper middle Eocene to upper Eocene sediments at Sites 689 and 690 . However, discoasters are still few to common in age-equivalent sediments in the lower latitude Sites 511 and 512 in the Falkland Plateau region. In addition, as noted above, Coccolithus formosus is virtually missing in the upper middle Eocene and younger sediments at Sites 689 and 690 , whereas the species is few to common in the Falkland Plateau material. This indicates that as early as the late middle Eocene there is a clear thermal gradient between the surface waters on Maud Rise and those on the Falkland Plateau region, and that the surface water temperature on Maud Rise

\section{Coccolithus formosus}

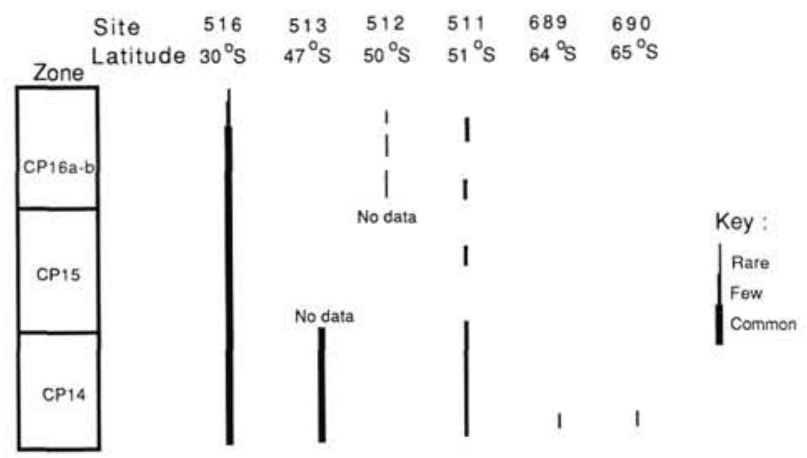

Figure 15. Simplified distribution patterns of Coccolithus formosus through time in a latitudinal transect. Data are taken from: Wise (1983) for Sites 511, 512, and 513; Wei and Wise (1989) for Site 516; the present study for Sites 689 and 690 . 
was low enough to exclude discoasters and C. formosus. The surface waters on the Falkland Plateau region were warmer than at Maud Rise but were considerably cooler compared with those in the mid- and low latitudes. This can be seen by the generally low species diversity, virtual absence of sphenoliths and helicosphaerids, and the dominance of chiasmoliths and reticulofenestrids in the assemblages of the Falkland Plateau material. The remarkably similar calcareous nannofossil species diversity and composition in sediments on Maud Rise and on the Falkland Plateau show that by the early Oligocene, cool or cold antarctic waters had expanded to the Falkland Plateau region.

The major hiatus identified at the Oligocene/Miocene boundary at both Sites 689 and 690 supports the hypothesis that the Drake Passage opened about this time (Barker and Burrell, 1977, 1982) and that the deep-water Antarctic Circumpolar Current was established. Hiatuses at the Oligocene/Miocene boundary have also been observed at other Southern Ocean sites in the Falkland Plateau region (Wise, 1983), on the Kerguelen Plateau in the southern Indian Ocean (Leg 119 Scientific Drilling Party, 1988), and are believed to be a global phenomenon by Keller et al. (1987). Reworking of calcareous nannofossils above the Oligocene/Miocene hiatus at Maud Rise, however, is considerably less severe than at sites to the north in the Falkland Plateau region, which lie directly in the path of the Antarctic Circumpolar Current.

There are sharp fluctuations in calcareous nannofossil abundance in the Miocene sediments from Maud Rise. The alternating biosiliceous and diatom-bearing nannofossil ooze facies may reflect fluctuations in water mass characteristics. In addition, Coccolithus pelagicus and one or two species of Reticulofenestra exhibit extreme fluctuations in assemblage dominance on a meter to decimeter scale. Haq (1980) attributes these sharp fluctuations to climate-induced, latitudinal migrations of Antarctic or warmer water assemblages across the South Atlantic during the Miocene. Flora dominated by Reticulofenestra perplexa represent the colder water and southernmost assemblage whereas C. pelagicus dominated assemblages denote a somewhat warmer association.
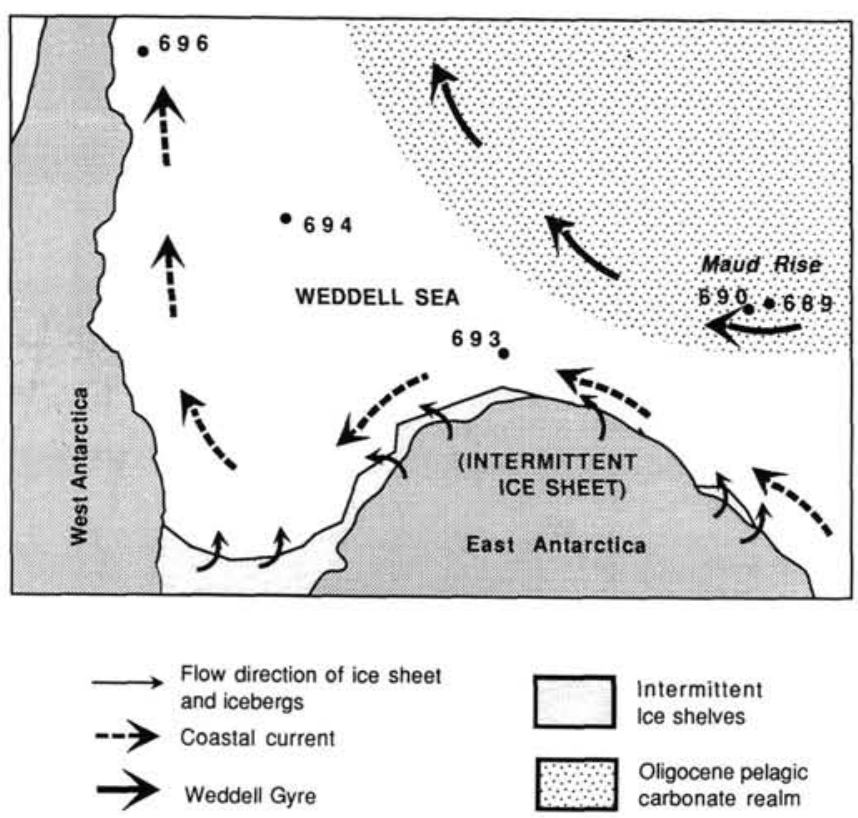

Figure 16. Sketch map showing suggested disposition of continental ice and circulation systems for Oligocene glacial episodes. The pelagic carbonate realm covers those areas that would receive nannofossil ooze at water depths above $3000 \mathrm{~m}$.
Comparing the calcareous nannofossil record of the middle Eocene through the Miocene time, we can see that calcareous nannofossils are abundant at Maud Rise whereas calcareous nannofossil assemblages of low diversity are present only in a few short intervals at Sites 693 and 696. The assemblages at Maud Rise show warmer water characteristics than those at Site 693 or even those at Site 696 , which is at a lower latitude.

It can be inferred that Maud Rise was bathed from the northeast by somewhat warmer surface return currents of the Weddell Gyre. These currents moved westward along the Antarctic margin and, in Oligocene glacial periods, were cooled by marginal ice shelves and/or sea-ice, before turning north and passing Site 696 (Fig. 16). Coupled with this was the coastal surface current which was considerably cooler. The effect of the marginal ice and ice shelves was: (1) to cool surface waters below the life tolerance of the calcareous nannoplankton, thus inhibiting productivity; and (2) to form corrosive bottom waters capable of dissolving most of the skeletal carbonate produced. The overall effect was to raise the CCD close to the continent, thereby leaving more of the sediments drilled at Site 693 and 696 devoid of calcareous nannofossils. The warm Brazil Current in the South Atlantic did not extend into the Weddell Sea and did not influence surface water conditions at Site 696 from the late Eocene through the Pleistocene. During interglacial periods of the Oligocene, the return currents of the Weddell gyre extended further south; consequently the pelagic carbonate realm expanded to Site 693 (Fig. 17), where several intervals of upper Oligocene carbonate ooze were found on the margin of East Antarctica.

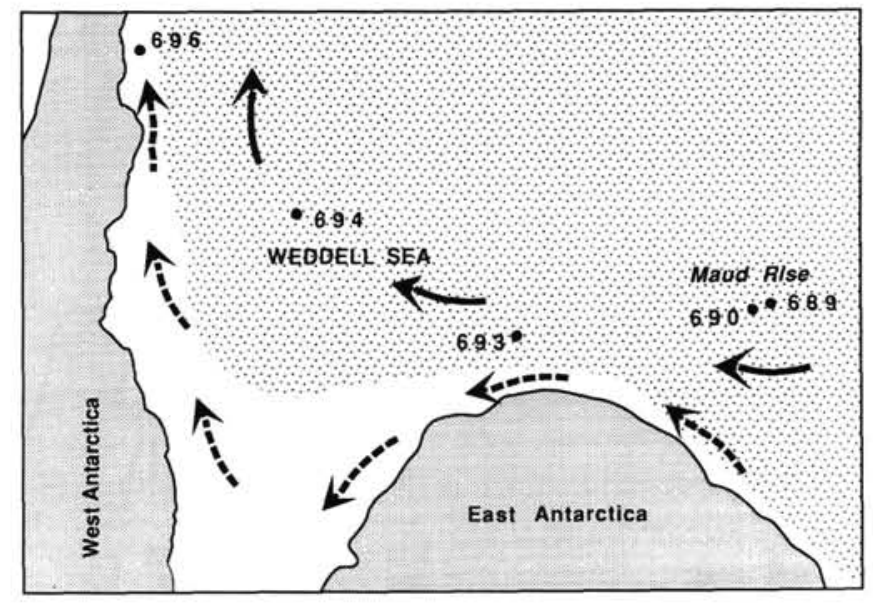

Figure 17. Sketch map showing suggested disposition of continental ice and circulation systems for a late Oligocene interglacial event. See Figure 16 for explanation.

\section{SYSTEMATIC PALEONTOLOGY}

Genus BICOLUMNUS Wei and Wise, n. gen.

Type species. Bicolumnus ovatus Wei and Wise, n. sp.

Diagnosis. A genus of the Coccolithaceae characterized by a thick column (presumably distal shield) attached to a thinner column (presumably proximal shield) in the center.

Description. Both columns consist of slightly inclined and counterclockwise overlapping elements. Central area of the distal shield is covered with laths and no central opening is visible.

Remarks. This genus differs from Pyrocyclus Hay and Towe (1962) in having two shields instead of a single shield, and no central opening. It can be easily differentiated from Reticulofenestra Hay Mohler, and Wade (1966) by its two column-like shields. The strong birefringence of both shields also distinguish it from other genera of the Coccolithaceae. 
Bicolumnus ovatus Wei and Wise, n. sp

(Pl. 1, Figs. 1-10)

Reticulofenestra placomorpha (Kamptner) Stradner and Edwards, 1968, p. 22 , pl. 22 , fig. 3 .

Cyclolithella sp., Martini, 1976, p. 406, pl. 5, figs. 1, 2.

Description. A species of Bicolumnus with oval shape in plan view. Laths in the distal shield incline to the center and cover the central area, leaving no central opening. The proximal shield elements also incline to the center, but no additional layer of laths covers the proximal shield. Both shields have the same length and width. Each shield consists of $60-70$ elements (holotype $=67$ ).

Remarks. Bicolumnus ovatus differs from Reticulofenestra bisecta and Reticulofenestra scrippsae in having much stronger birefringence because of its two column-like shields, and having two shields forming two opposite "funnels." Bicolumnus ovatus differs from species of $P y$ rocyclus (i.e., $P$. hermosus, $P$. inversus, and $P$. orangensis) in having two shields instead of one, and in having no central opening.

Occurrence. Rare to few in upper Eocene and Oligocene material from Maud Rise. Martini (1976, p. 407) figured this species under $C y$ clolithella sp. from the upper Eocene sediment of the Central Pacific Ocean. In addition, rare specimens have been observed in the upper Eocene-Oligocene sediment from Rio Grande Rise and Falkland Plateau in the South Atlantic (Wei, unpubl. data).

Size. Holotype: $6.5 \mu \mathrm{m} \times 5 \mu \mathrm{m}$; isotype: 5.5-7 $\mu \mathrm{m} \times 4.5-5.5 \mu \mathrm{m}$.

Holotype. Plate 1, Figure 1.

Isotypes. Plate 1, Figures 2-10.

Type locality. ODP Sample 113-689B-15H-3, 131-132 cm.

\section{ACKNOWLEDGMENTS}

We thank Drs. D. Bukry (U.S. Geological Survey), A. R. Edwards (New Zealand Geological Survey), and P. H. Roth (University of Utah) for their critical reviews, which greatly improved the quality of this paper. This research was supported by the U.S. Sciences Advisory Committee, NSF grant DDP8414268 , and an equipment grant from the Amoco Foundation to Wise, and by a Florida State University Dissertation Fellowship to Wei.

\section{REFERENCES}

Aubry, M.-P., 1983. Late Eocene to early Oligocene calcareous nannoplankton biostratigraphy and biogeography, Am. Assoc. Pet. Geol. Bull., 67:415.

Backman, J., 1980. Miocene-Pliocene nannofossils and sedimentation rates in the Hatton-Rockall Basin, NE Atlantic Ocean. Stockholm Contrib. Geol., 36:1-91.

1987. Quantitative calcareous nannofossil biochronology of middle Eocene through early Oligocene sediment from DSDP Sites 522 and 523. Abh. Geol. B.-A., 39:21-31.

Backman, J., and Hermelin, J.O.R., 1986. Morphometry of the Eocene nannofossil $R$. umbilica lineage and its biochronological consequences. Palaeogeogr., Palaeoclimatol., Palaeoecol., 57:103-106.

Barker, P. F., and Burrell, J., 1977. The opening of the Drake Passage. Mar. Geol., 25:15-34.

1982. The influence upon Southern Ocean circulation sedimentation, and climate of the opening of Drake Passage. In Craddock, C. (Ed.), Antarctic Geoscience., Univ. of Wisconsin Press, 377-385.

Barker, P. F., Kennett, J. P., et al., 1988. Proc. ODP, Init. Repts., 113: College Station, TX (Ocean Drilling Program).

Berggren, W. A., Kent, D. V., and Flynn, J., 1985. Paleogene geochronology and chronostratigraphy. In Snelling, N. J. (Ed.), The chronology of the geological record. The Geological Society, London, 141-195.

Biolzi, M., 1985. The Oligocene/Miocene boundary in selected Atlantic, Mediterranean and Paratethyan sections based on stratigraphic and stable isotope evidence. Memorie Di Scienze Geologiche, 37: 303-376.

Bukry, D., 1973. Coccolith stratigraphy, eastern equatorial Pacific, Leg 16, Deep Sea Drilling Project. In van Andel, T. H., Heath, G. R., et al., Init. Repts. DSDP, 16: Washington (U.S. Govt. Printing Office), 653-711.
1977. Cenozoic coccolith and silicoflagellate stratigraphy, offshore northwest Africa, Deep Sea Drilling Project Leg 41. In Lancelot, Y., Seibold, E., et al., Init. Repts. DSDP, 41: Washington (U. S. Govt. Printing Office), 689-719.

1978. Biostratigraphy of Cenozoic sediment by calcareous nannofossils. Micropaleontology, 24:44-60.

Burns, D. A., 1975. Nannofossil biostratigraphy for Antarctic sediments, Leg 28, Deep Sea Drilling Project. In Hays, D. E., Frakes, L. A., et al., Init. Repts. DSDP, 28: Washington (U.S. Govt. Printing Office), 589-698.

Dowsett, H. J., 1988. Diachrony of late Neogene microfossils in the southwest Pacific Ocean: Application of the graphic correlation method. $\mathrm{Pa}$ leoceanography, 3:209-222.

Edwards, A. R., 1971. A calcareous nannoplankton zonation of the New Zealand Paleogene. In Farinacci, A. (Ed.), Proceeding II Planktonic Conference Rome, 1970, Roma (Edizioni Technoscienza). 1: 381-489.

1973. Calcareous nannofossils from the southwest Pacific Deep Sea Drilling Project, Leg 21. In Burns, R. E., Andrews, J. E., et. al., Init. Repts. DSDP, 21: Washington (U.S. Govt., Printing Office), 641-691.

Edwards, A. R., and Perch-Nielsen, K., 1975. Calcareous nannofossils from the southern Southwest Pacific, Deep Sea Drilling Project, Leg 29. In Kennett, J. P., Houtz, R. E., et al., Init. Repts. DSDP, 29: Washington (U.S. Govt. Printing Office), 469-539.

Edwards, A. R., and Waghorn, D. B., 1989. Calcareous nannofossils. In Barrett, P. J. (Ed.), Antarctic Cenozoic history from the CIROSdrillhole, McMurdo Sound. DSIR Bulletin, 245:145-149.

Haazel, J. E., 1988. Chronostratigraphy of upper Eocene microspherule layers. Geol. Soc. Am. Abstr. Progr., 20:A177-178.

Haq, B. U., 1976. Coccoliths in cores from the Bellingshausen abyssal plain and Antarctic continental rise. In Hollister, C. D., Craddock, C., et al., Init. Repts. DSDP, 35: Washington (U.S. Govt. Printing Office), 557-567.

1980. Biogeographic history of Miocene calcareous nannoplankton and paleoceanography of the Atlantic Ocean. Micropaleontology, 26:414-443.

Haq, B. U., and Lohmann, G. P., 1976. Early Cenozoic calcareous nannoplankton biogeography of the Atlantic Ocean. Mar. Micropaleontol., 1:119-194.

Haq, B. U., Lohmann, G. P., and Wise, S. W., 1977. Calcareous nannoplankton biogeography and its paleoclimatic implications: Cenozoic of the Falkland Plateau (DSDP Leg 36) and Miocene of the Atlantic Ocean. In Barker, P. F., Dalziel, L.W.D., et al., Init. Repts. DSDP, 36: Washington (U.S. Govt. Printing Office), 745-760.

Haq, B. U., Perch-Nielsen, K., and Lohmann, G. P., 1977. Contribution to the Paleocene calcareous nannofossil biogeography of the central and southwest Atlantic Ocean (Ceara Rise and Sao Paulo Plateau, DSDP Leg 39). In Perch-Nielsen, K., Supko, P. R., et al., Init. Repts. DSDP, 39: Washington (U.S. Govt. Printing Office), 841-848.

Hay, W. W., 1970. Calcareous nannofossils from cores recovered on Leg 4. In Bader, R. G., Gerard, R. D., et al., Init. Repts. DSDP, 4 Washington (U.S. Govt. Printing Office), 455-501.

Hay, W. W., Mohler, H. P., and Wade, M. E., 1966. Calcareous nannofossils from Nal'chik (northwest Caucasus). Eclog. Geol. Helv., 59: 379-399.

Hay, W. W., and Towe, K. M., 1962. Electron microscope examination of some coccoliths from Donzacq (France). Eclog. Geol. Helv., 55: 497-517.

Hays, D. E., Frakes, L. A., et al., 1975. Init. Repts. DSDP, 28: Washington (U.S. Govt. Printing Office).

Heck, S. E., van, 1979a. Bibliography and taxa of calcareous nannoplankton. Int. Nannoplankton Assoc. Newsl., 1:AB1-5, A1-12, B1-27.

1979b. Bibliography and taxa of calcareous nannoplankton. Int. Nannoplankton Assoc. Newsl., 1:ABV1, A13-28, B28-42.

1980a. Bibliography and taxa of calcareous nannoplankton. Int. Nannoplankton Assoc. Newsl., 2:5-34.

$1980 \mathrm{~b}$. Bibliography and taxa of calcareous nannoplankton. Int. Nannoplankton Assoc. Newsl., 2:43-81.

1981a. Bibliography and taxa of calcareous nannoplankton. Int. Nannoplankton Assoc. Newsl., 3:4-41.

1981b. Bibliography and taxa of calcareous nannoplankton. Int. Nannoplankton Assoc. Newsl., 3:51-86. 
1982a. Bibliography and taxa of calcareous nannoplankton. Int. Nannoplankton Assoc. Newsl., 4:7-50.

1982b. Bibliography and taxa of calcareous nannoplankton. Int. Nannoplankton Assoc. Newsl., 4:65-92.

1983. Bibliography and taxa of calcareous nannoplankton. Int. Nannoplankton Assoc. Newsl., 5:4-13.

Hollister, C. D., Craddock, C., et al., 1976. Init. Repts. DSDP, 35: Washington (U.S. Govt. Printing Office).

Keller, G., Herbert, T., Dorsey, R., D'Hondt, S., Johnson, M., and Chi, W. R., 1987. Global distribution of late Paleogene hiatuses. Geology, 15:199-203.

Leg 119 Scientific Drilling Party, 1988. Leg 119 studies climatic history. Geotimes, July 1988, 14-16.

Loeblich, A. R., Jr., and Tappan, H., 1966. Annotated index and bibliography of the calcareous nannoplankton. Phycologia, 5:81-216. 1968. Annotated index and bibliography of the calcareous nannoplankton II. J. Paleontol., 42:584-598.

1969. Annotated index and bibliography of the calcareous nannoplankton III. J. Paleontol., 43:586-588. 1970a. Annotated index and bibliography of the calcareous nannoplankton IV. J. Paleontol., 44:585-574. 1970b. Annotated index and bibliography of the calcareous nannoplankton V. Phycologia, 9:157-174.

1971. Annotated index and bibliography of the calcareous nannoplankton VI. Phycologia, 10:315-339.

1973. Annotated index and bibliography of the calcareous nannoplankton VII. J. Paleontol. 47:715-759.

Lowrie, W., Alvarez, W., Napoleone, G., Perch-Nielsen, K., Premoli Silva, I., and Toumarkine, M., 1982. Paleogene magnetic stratigraphy in Umbrian pelagic carbonate rocks: the Contessa sections, Gubbio. Geol. Soc. Am. Bull., 93:411-432.

Martini, E., 1970. Standard Paleogene calcareous nannoplankton zonation. Nature, 226:560-561.

1971. Standard Tertiary and Quaternary calcareous nannoplankton zonation. In Farinacci A. (Ed.), Proceedings II Planktonic Conference, Roma 1970, Roma (Edizioni Technoscienza) 2:739-785.

1976. Cretaceous to Recent calcareous nannoplankton from the Central Pacific Ocean (DSDP Leg 33). In Schlanger, S. O., Jackson, E. D., et al., Init. Repts. DSDP, 33: Washington (U.S. Govt. Printing Office), 383-423.

1986. Paleogene calcareous nannoplankton from the southwest Pacific Ocean, Deep Sea Drilling Project, Leg 90. In Kennett, J. P., von der Borch, C. C., et al., Init. Repts. DSDP, 90: Washington (U.S. Govt. Printing Office), 747-761.

Martini, E., and Müller, C., 1986. Current Tertiary and Quaternary calcareous nannoplankton stratigraphy and correlations. Newsl. Stratigr. 16:99-112.

McIntyre, A., Be, A.W.H., and Roche, M. B., 1970. Modern Pacific coccolithophorida: A paleontological thermometer. New York Acad. Sci., Trans. 32:720-731.

Miller, K. G., Aubry, M-P., Khan, M. J., Melillo, A. J., Kent, D. V., and Berggren, W. A., 1985. Oligocene-Miocene biostratigraphy, magnetostratigraphy, and isotopic stratigraphy of the western North Atlantic. Geology, 13:257-261.

Monechi, S., and Thierstein, H. R., 1985. Late Cretaceous-Eocene nannofossil and magnetostratigraphic correlations near Gubbio, Italy. Mar. Micropaleontol., 9:419-440.

Moshkovitz, S., 1978. New types of cover-slip and mounting-slide with a graticule for examination of the same small object both by the light microscope and the scanning electron microscope. Microscopica Acta, 80:161-166.

Müller, C., 1970. Nannoplankton aus dem Mittel-Oligozän von Norddeutschland und Belgien. Neues Jahrb. Geol. Palaeontol., 135:82101.

1979. Calcareous nannofossils from the North Atlantic (Leg 48). In Montadert, L., Robert, D. G., et al., Init. Repts. DSDP, 48: Washington (U.S. Govt. Printing Office), 589-639.

Okada, H., and Bukry, D., 1980. Supplementary modification and introduction of code numbers to the low-latitude coccolith biostratigraphic zonation (Bukry 1973, 1975). Mar. Micropaleontol., 5:321325.

Parker, M. E., Clark, M., and Wise, S. W., Jr., 1985. Calcareous nannofossils of Deep Sea Drilling Project Sites 558 and 563, North Atlantic Ocean: Biostratigraphy and the distribution of Oligocene braarudosphaerids. In Bougault, H., Cande, S. C., et al., Init. Repts. DSDP, 82: Washington (U.S. Govt. Printing Office), 559-589.
Perch-Nielsen, K., 1977. Albian to Pleistocene calcareous nannofossils from the western South Atlantic. In Perch-Nielsen, K., Supko, P. R., et al., Init. Repts. DSDP, 39: Washington (U.S. Govt. Printing Office), 699-823.

1985. Cenozoic nannofossils. In Bolli, H. M., Saunders, J. B., and Perch-Nielsen, K. (Eds.), Plankton stratigraphy: Cambridge (Cambridge Univ. Press), 427-554.

1986. Calcareous nannofossil events at the Eocene/Oligocene boundary. In Pomerol, C., and Peremoli-Silva, I. (Eds.), Terminal Eocene Events: Amsterdam (Elsevier Science Publisher), 275282.

Percival, S. F., Jr., 1984. Late Cretaceous to Pleistocene calcareous nannofossils from the South Atlantic, Deep Sea Drilling Project Leg 73. In Hsü, K. J., LeBrecque, J. L., et al., Init. Repts. DSDP, 73: Washington (U.S. Govt. Printing Office), 391-421.

Poore, R. Z., Tauxe, L., Percival, S. F., Jr., LaBrecque, J. L., Wright, R., Petersen, N. P., Smith, C. C., Tucher, P., and Hsü, K. J., 1984. Late Cretaceous-Cenozoic magnetostratigraphic and biostratigraphic correlations for the South Atlantic Ocean, Deep Sea Drilling Project Leg 73. In Hsü, K. J., LaBrecque, J., et al., Init. Repts. DSDP, 73: Washington (U.S. Govt. Printing Office), 645-655.

Prell, W. L., Imbrie, J., Marinson, D. G., Morley, J. J., Pisias, N. G., Shackleton, N. J., and Streeter, H. F., 1986. Graphic correlation of oxygen isotope stratigraphy application to the late Quaternary. Paleoceanography, 1:137-162.

Roth, P. H., and Thierstein, H. R., 1972. Calcareous nannoplankton: Leg 14 of the Deep Sea Drilling Project. In Hayes, D. E., Pimm, A. C., et al., Init. Repts. DSDP, 14: Washington (U.S. Govt. Printing Office), 421-485.

Shackleton, N. J., Moore, T. C., Jr., Rabinowitz, P. D., Boersma, A., Borella, P. E., Chave, A. D., Duee, G., Fütterer, D., Jiang, M.-J., Kleinert, K., Lever, A., Manivit, H., O'Connell, S., and Richardson, S. H., 1984. Accumulation rates in Leg 74 sediments. In Moore, T. C., Jr., Rabinowitz, P. D., et al., Init. Repts. DSDP, 74: Washington (U.S. Govt. Printing Office), 621-637.

Shafik, S., 1981. Nannofossil biostratigraphy of the Hantkenina (foraminiferid) interval in the upper Eocene of southern Australia. J. Austral. Geol. Geophys., 6:108-116.

1985. Cretaceous coccoliths in the middle Eocene of the western and southern margins of Australia: evidence of a significant reworking episode. BMR J. Austral. Geol. and Geophys., 9:353-359.

Shaw, A. B., 1964. Time in Stratigraphy: New York (McGraw-Hill Book Co.).

Siesser, W. G., 1984. Paleogene sea levels and climates: U.S.A. eastern Gulf Coastal plain. Palaeogeogr., Palaeoclimatol., Palaeoecol., 47: 262-275

Steinmetz, J. C., 1985a. Bibliography and taxa of calcareous nannoplankton V. Int. Nannoplankton Assoc. Newsl., 7:5-28.

1985b. Bibliography and taxa of calcareous nannoplankton Vl. Int. Nannoplankton Assoc. Newsl., 7:122-145.

1986. Bibliography and taxa of calcareous nannoplankton VIII. Int. Nannoplankton Assoc. Newsl., 8:66-87.

1987. Bibliography and taxa of calcareous nannoplankton IX. Int. Nannoplankton Assoc. Newsl., 9:8-29.

Stradner, H., and Edwards, A. R., 1968. Electron microscopic studies on upper Eocene coccoliths from the Oamaru diatomite, New Zealand. Jahrb. der Geologischen Bundesantalt, Sonderband 13, 1-66.

Wei, W., and Wise, S. W., Jr., 1989. Paleogene calcareous nannofossil magnetobiochronology: Results from South Atlantic DSDP Site 516. Mar. Micropaleontol., 14:119-152.

Wise, S. W., Jr., 1973. Calcareous nannofossils from cores recovered during Leg 18, Deep Sea Drilling Project: biostratigraphy and observations on diagenesis. In Kulm, L. D., von Huene, R., et al., Init. Repts. DSDP, 18: Washington (U.S. Govt. Printing Office), 569615.

1977. Chalk formation: Early diagenesis. In Anderson, N. R., and Malahoff, A. (Eds.), The Fate of Fossil Fuel $\mathrm{CO}_{2}$ in the Oceans (Marine Science, Vol. 6). New York (Plenum), 717-739.

1983. Mesozoic and Cenozoic calcareous nannofossils recovered by Deep Sea Drilling Project Leg 71 in the Falkland Plateau region, Southwest Atlantic Ocean. In Ludwig, W. J., Krasheninnikov, V. A., et al., Init. Repts. DSDP, 71: Washington (U.S. Govt. Printing Office), 481-550.

1988. Mesozoic-Cenozoic history of calcareous nannofossils in the region of the Southern Ocean. Palaeogeogr. Palaeoclimatol., Palaeoecol., 67:157-179. 
Wise, S. W., Jr., and Wind, F. H., 1977. Mesozoic and Cenozoic calcareous nannofossils recovered by DSDP Leg 36 drilling on the Falkland Plateau, Southwest Atlantic sector of the Southern Ocean. In Barker, P. F., Dalziel, I.W.D., et al., Init. Repts. DSDP, 36: Washington (U.S. Govt. Printing Office), 269-492.

Wise, S. W., Jr., and Mostajo, E. L., 1983. Correlation of Eocene-Oligocene calcareous nannofossil assemblages from piston cores taken near Deep Sea Drilling Sites 511 and 512, southwest Atlantic Ocean. In Ludwig, W. J., Krasheninnikov, V. A., et al. Init. Repts. DSDP, 71: Washington (U.S. Govt. Printing Office), 1171-1180.

Date of initial receipt: 19 December 1988

Date of acceptance: 20 June 1989

Ms 113B-125

\section{APPENDIX}

\section{Calcareous Nannofossils Considered in This Paper}

(Genera in alphabetical order (plate and figure numbers refer to illustrations in this paper).

(Bicolumnus ovatus n. gen., n. sp. Pl. 1, Figs. 1-10.

Blackites spinosus (Deflandre and Fert) Hay and Towe, 1962. Pl. 5, Fig. 5. Braarudosphaera bigelowii (Gran and Braarud) Deflandre, 1974.

Calcidiscus leptoporus (Murray and Blackman) Loeblich and Tappan, 1978. Pl. 6, Fig. 12.

Chiasmolithus altus Bukry and Percival, 1971. Pl. 2, Fig. 10.

Chiasmolithus expansus (Bramlette and Sullivan) Gartner, 1970. Pl. 5, Fig. 7.

Chiasmolithus grandis (Bramlette and Sullivan) Radomski, 1978.

Chiasmolithus oamaruensis (Deflandre) Hay, Mohler and Wade, 1966. Pl. 5, Fig. 6.

Chiasmolithus solitus (Bramlette and Sullivan) Locker, 1968. Pl. 5, Fig. 8.
Clausicoccus fenestratus (Deflandre and Fert) Prins, 1979. Pl. 6, Figs. $8,9$.

Coccolithus formosus (Kamptner) Wise, 1973.

Coccolithus pelicus (Wallich) Schiller, 1930. Pl. 2, Figs. 1-9.

Cyclicargolithus abisectus (Müller) Wise, 1973. Pl.4, Fig.13.

Cyclicargolithus floridanus (Roth and Hay in Hay et al.) Bukry, 1971. Pl. 3, Fig. 7; Pl. 4, Figs. 11, 12.

Gephyrocapsa oceanica Kamptner, 1943.

Isthmolithus recurvus Deflandre, 1954. Pl. 5, Figs. 11, 12; Pl. 6, Fig. 4.

Markalius inversus (Deflandre) Bramlette and Martini, 1964. Pl. 5, Figs. 15 and 16; Pl. 6, Fig. 5.

Neococcolithes dubius (Deflandre) Black, 1967. Pl. 5, Fig. 9.

Pseudoemiliania lacunosa (Kamptner) Gartner, 1969.

Reticulofenestra bisecta (Hay, Mohler, and Wade) Roth, 1970. Pl. 4, Fig. 3, 4; PI. 5, Fig. 3.

Reticulofenestra bisecta filewiczii Wise and Wiegand in Wise, 1983. Pl. 5, Fig. 4.

Reticulofenestra daviesii (Haq) Haq, 1971. Pl. 3, Figs. 8, 9; Pl. 6, Figs. $10,11$.

Reticulofenestra gelida (Geitzenauer) Backman, 1978. Pl. 4, Fig. 9.

Reticulofenestra hesslandii (Haq) Roth, 1970. Pl. 3, Figs. 4-6; Pl. 4, Fig. 8.

Reticulofenestra oamaruensis (Deflandre) Stradner and Edwards, 1968. PI. 4, Figs. 1, 2.

Reticulofenestra perplexa (Burns) Wise, 1983. Pl. 3, Figs. 1-3; Pl. 4, Figs. 5-7.

Reticulofenestra pseudoumbilica (Gartner) Gartner, 1969. Pl. 4, Fig. 10.

Reticulofenestra reticulata (Gartner and Smith) Roth and Thierstein, 1972. Pl. 6, Figs. 2, 3, 6, 7.

Reticulofenestra samodurovii (Hay, Mohler and Wade) Roth, 1970. Pl. 5, Fig. 1; Pl. 6, Fig. 1.

Reticulofenestra umbilica (Levin) Madini and Ritzkowski, 1968. Pl. 5, Fig. 2.

Sphenolithus moriformis (Bronnimann and Stradner) Bramlette and Wilcoxon, 1967. Pl. 5, Fig. 14.

Zygrhablithus bijugatus (Deflandre) Deflandre, 1959. Pl. 5, Fig. 10. 


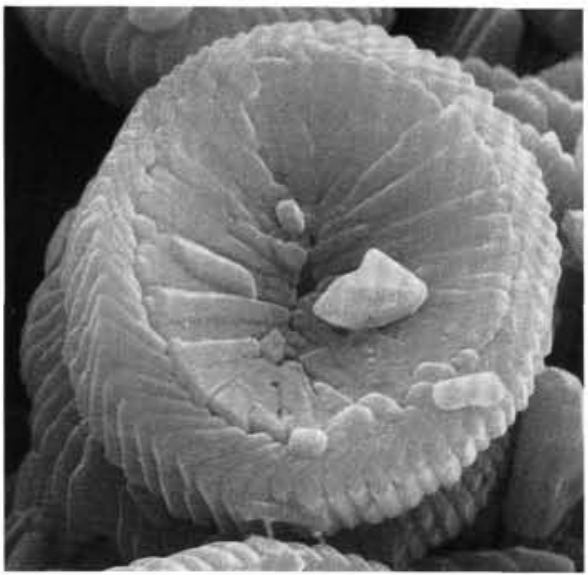

1
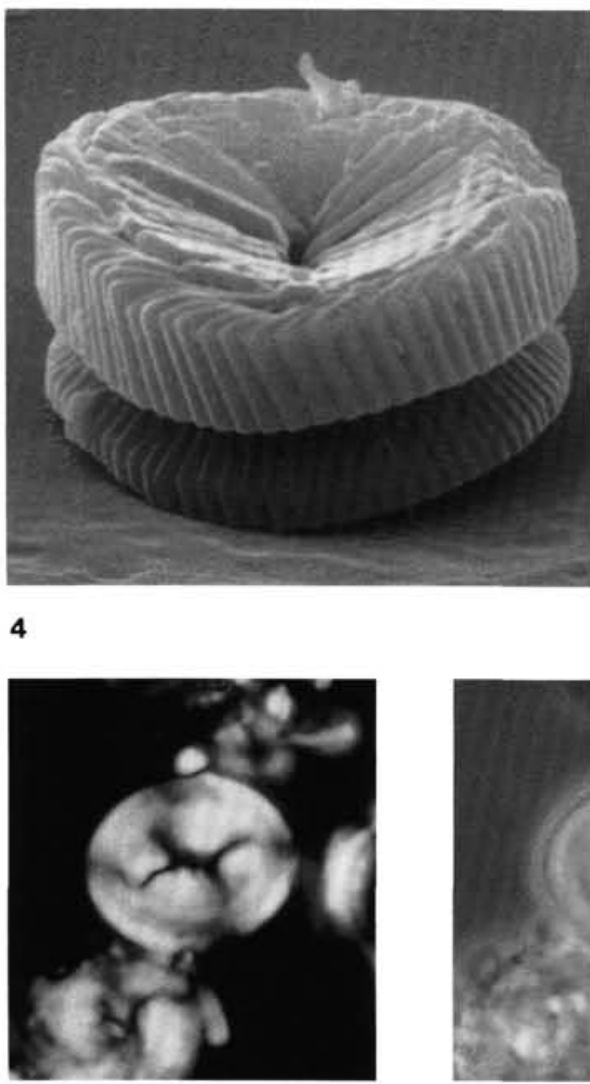
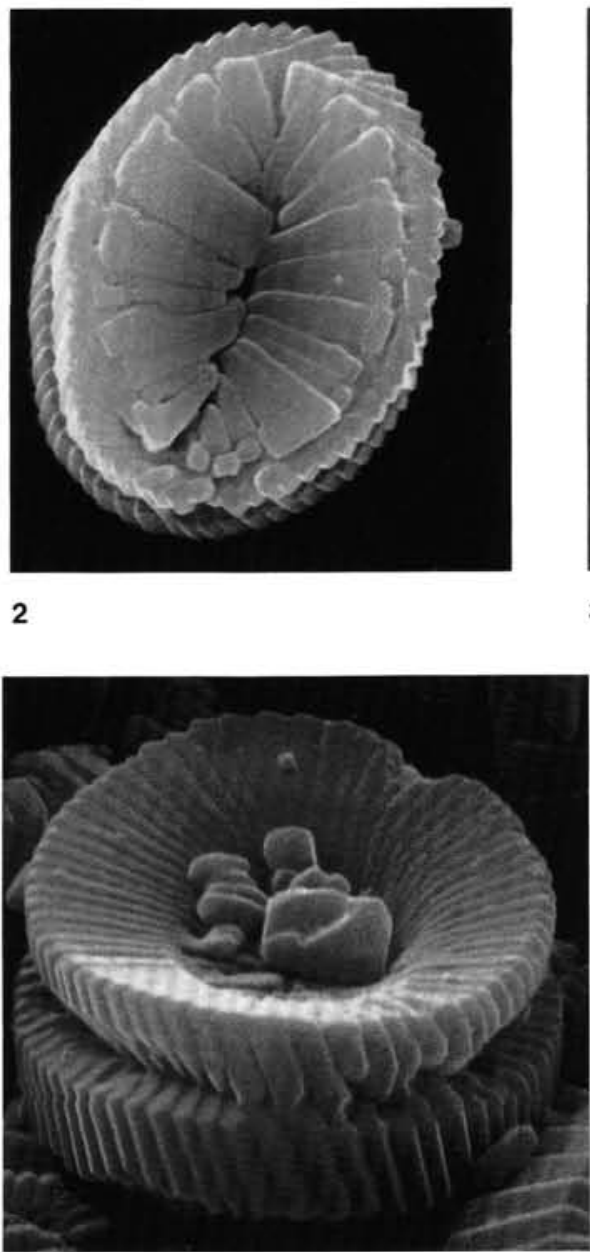

5

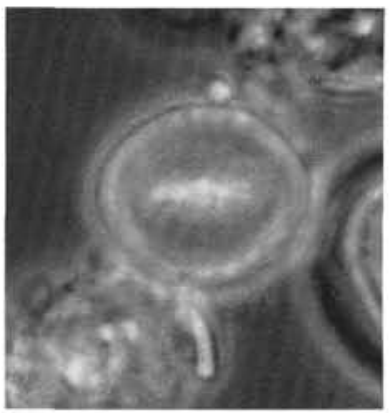

8

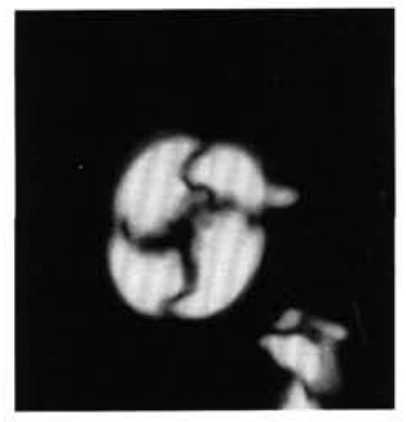

9
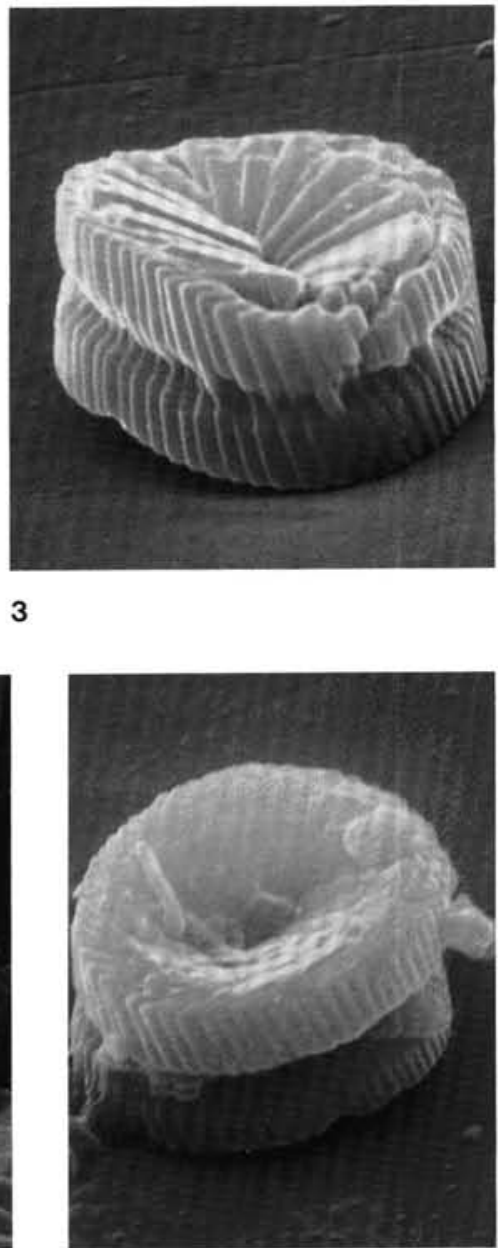

6

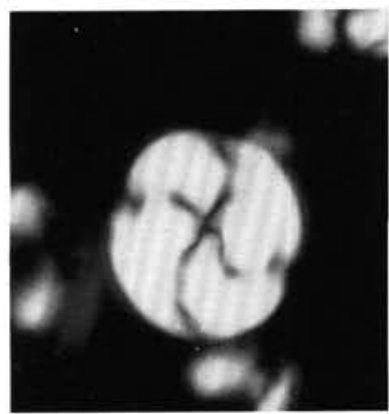

10

Plate 1. 1-10. Bicolumnus ovatus Wei and Wise, n. gen. n. sp. (1) Holotype, SEM, distal view, $\times 8,000$, Sample 113-689B-15H-3, 131-133 cm. (23) Same specimen (2, distal view, 3, side view), isotype, SEM, $\times 9,500$, Sample 113-689B-14H-6, 130-132 cm. (4) isotypes, SEM, oblique and distal view, $\times 8,000$, Sample 113-689B-14H-6, 130-132 cm. (5) isotype, SEM, Oblique and proximal view, $\times 9,000$, Sample 113-689B-15H-3, 131-133 cm. (6) isotype, SEM, Oblique and proximal view, $\times 9,000$, Sample $516 \mathrm{~F}-15-5,30-31 \mathrm{~cm}$. (7-8) Same specimen (7, cross-polarized; 8, phase contrast), isotype, $\times 3,000$, Sample 113-689B-15H-2, 131-133 cm. (9) isotype, cross-polarized, $\times 3,500$, Sample 113-689B-15H-4, 110-112 cm. (10) isotype, crosspolarized, $\times 3,500$, Sample $516 \mathrm{~F}-40-2,105-106 \mathrm{~cm}$. 


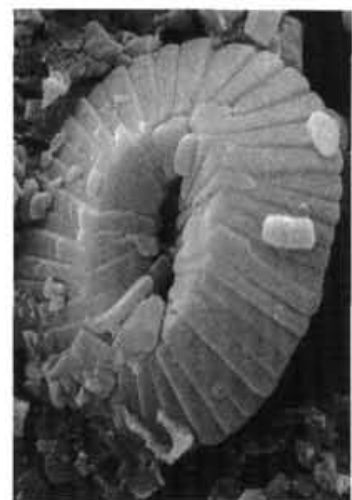

1
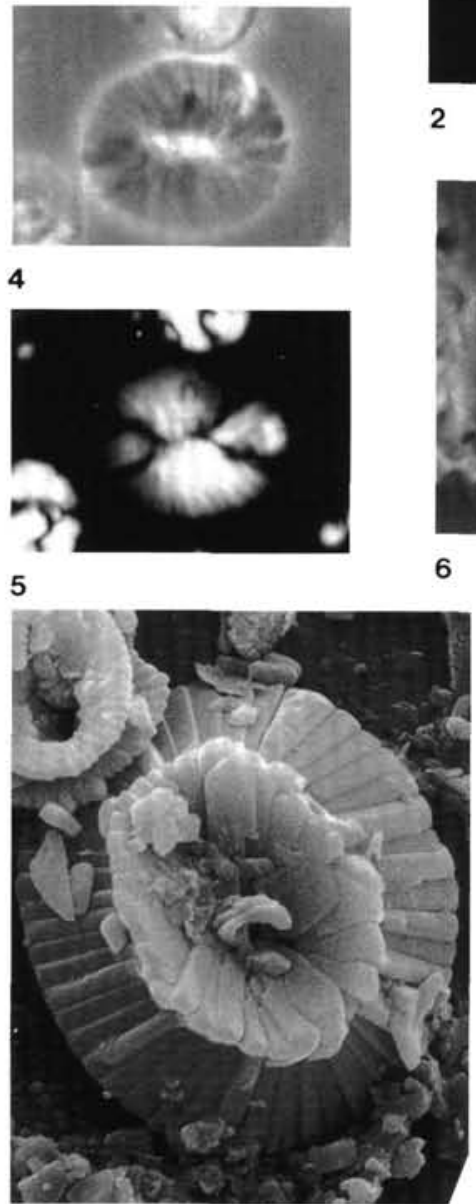

8

2

6
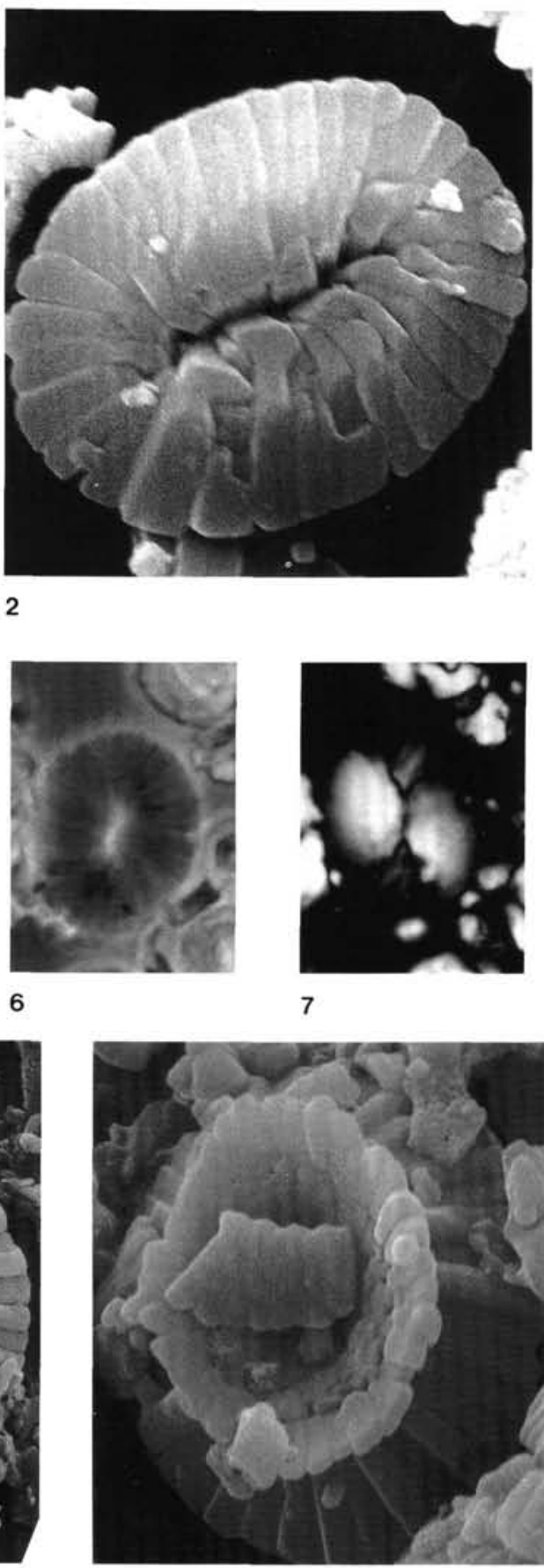

9

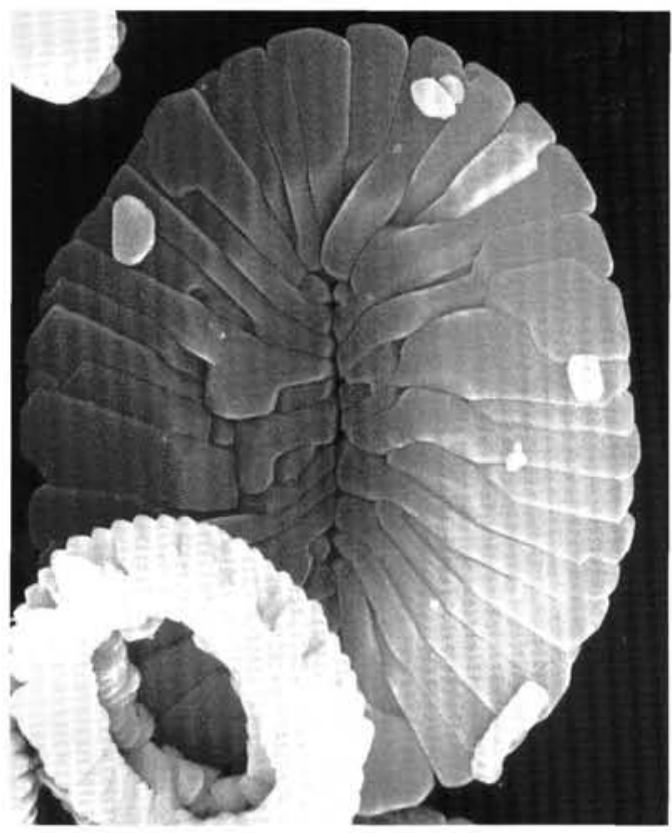

3

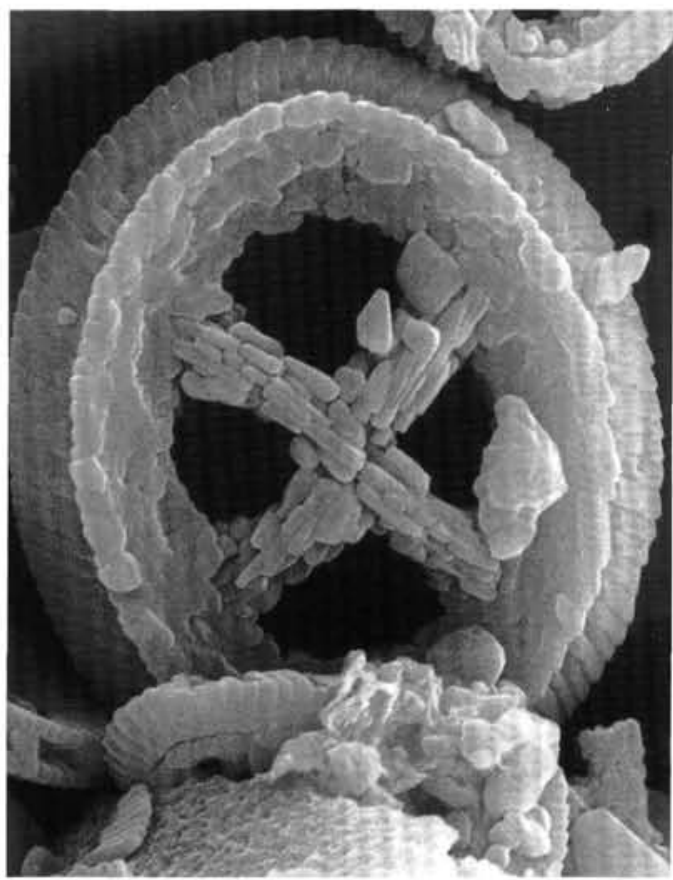

10

Plate 2. 1-9. Coccolithus pelagicus (Wallich) Schiller, all distal view. Note the variation in its central area and overgrowth effect. (1) SEM, $\times 5,000$, Sample 113-690B-6H-2, 28-30 cm. (2, 3) SEM, $\times 7,500$, Sample 113-689B-8H-4, 30-32 cm. (4) Phase contrast, $\times 2,200$, Sample 113-689B-8H-4, 30$32 \mathrm{~cm}$. (5) Cross-polarized, same specimen and same magnification as (4). (6) Phase contrast, $\times 2,200$, Sample 113-689B-8H-4, 30-32 cm. (7) Crosspolarized, same specimen and same magnification as (6). (8) SEM, $\times 4,500$, Sample 113-690B-6H-2, 28-30 cm. (9) SEM, $\times 5,000$, Sample 329B-27-1, $11-13 \mathrm{~cm}$. 10. Chiasmolithus altus Bukry and Percival, distal view, $\times 5,500$, Sample $113-689 \mathrm{~B}-14 \mathrm{H}-4,130-132 \mathrm{~cm}$. 


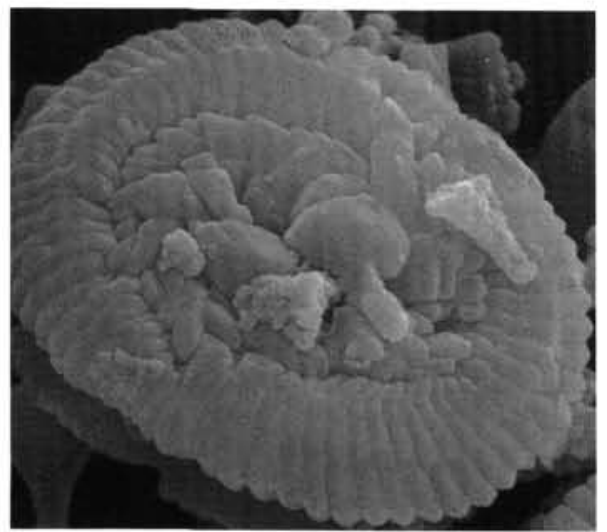

1
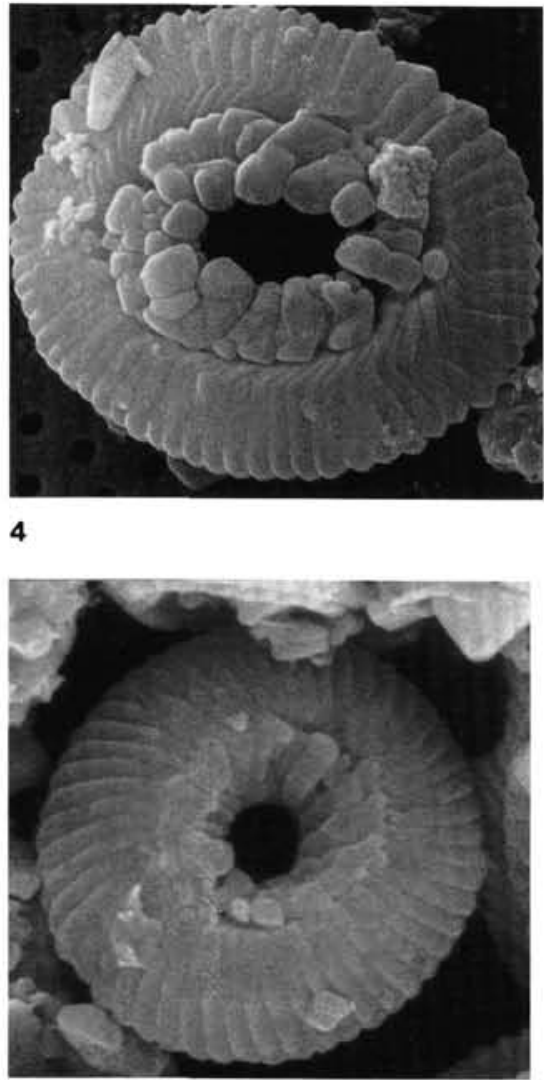

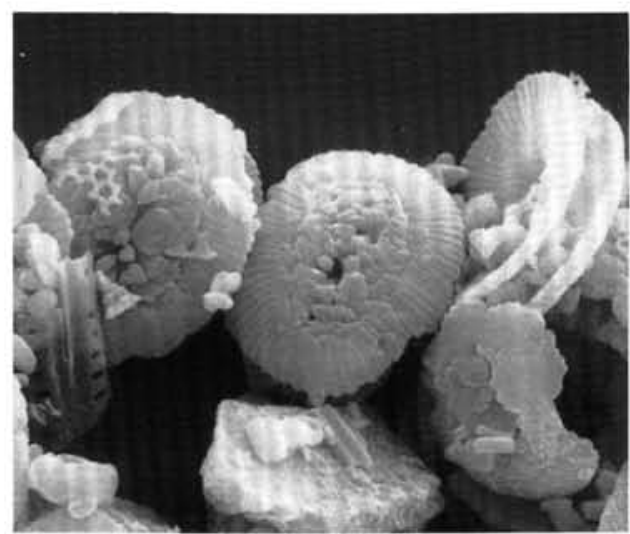

2

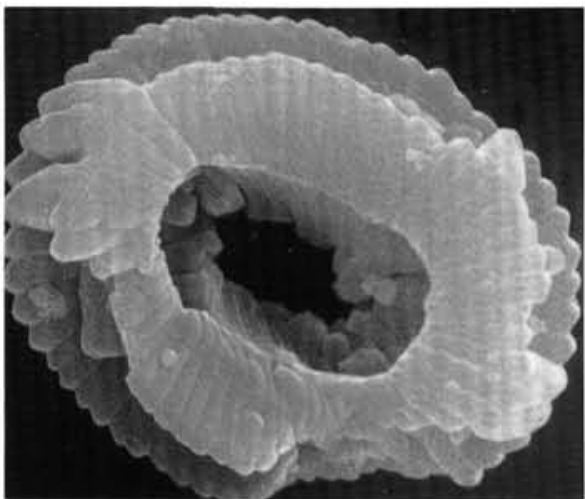

5

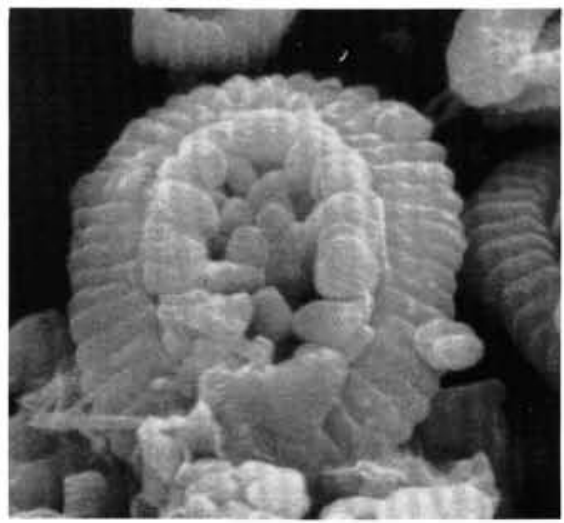

8

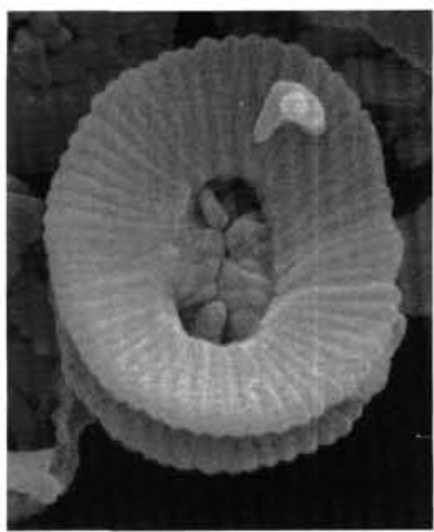

3
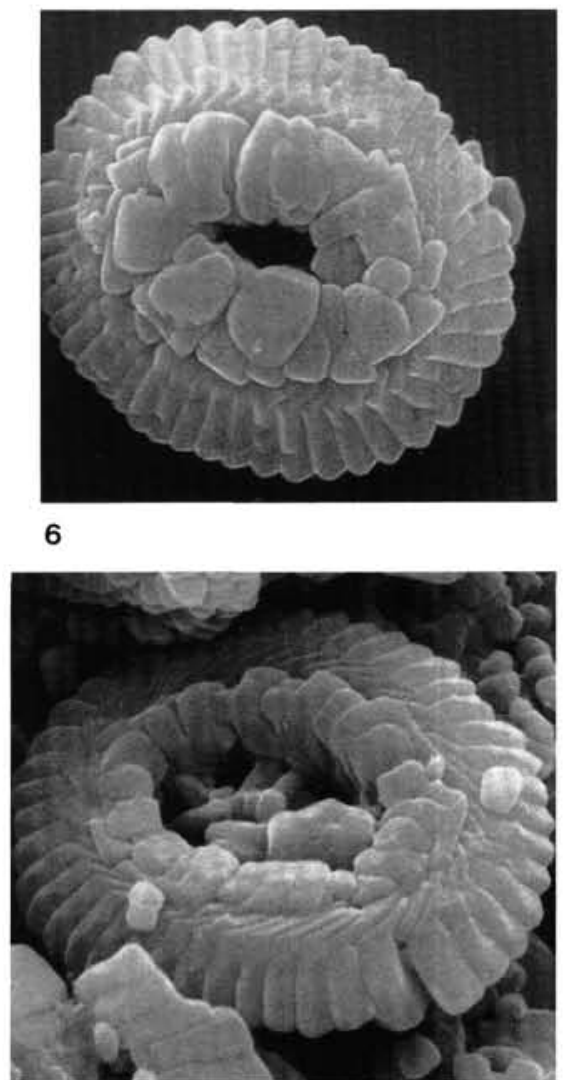

9

Plate 3. 1-3. Reticulofenestra perplexa (Burns) Wise, SEM. (1) Distal view, $\times 9,500$, Sample 113-689B-5H-3, 30-32 cm. (2) Distal view of two specimens in the center and on left; side view of one specimen on right, $\times 4,000$, Sample 113-689B-5H-2, 30-32 cm. (3) Proximal view, $\times 7,500$, Sample 113-689B-5H-3, 30-32 cm. 4-6. Reticulofenestra hesslandii (Haq) Roth, SEM, $\times 8,000$, Sample 113-689B-8H-2, 30-32 cm. 7. Cyclicargolithus floridanus (Roth and Hay) Bukry, SEM, distal view, $\times 8,000$, Sample 113-689B-9H-1, 29-3 $1 \mathrm{~cm}$. 8-9. Reticulofenestra daviesii (Haq) Haq, SEM, distal view. (8) $\times 8,000$, Sample 113-689B-9H-1, 29-31 cm. (9) $\times 9,500$, Sample $113-689 \mathrm{~B}-22 \mathrm{X}-1,132-134 \mathrm{~cm}$. 


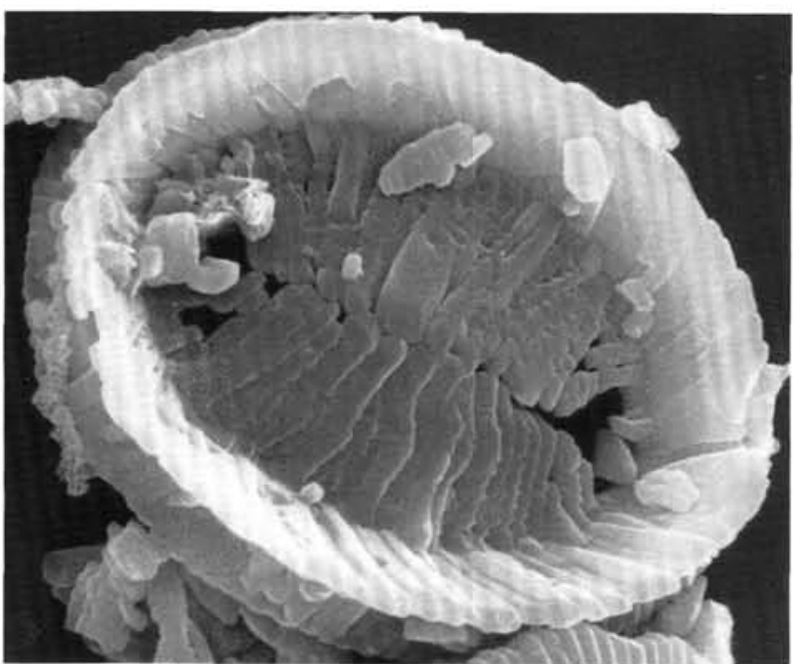

1

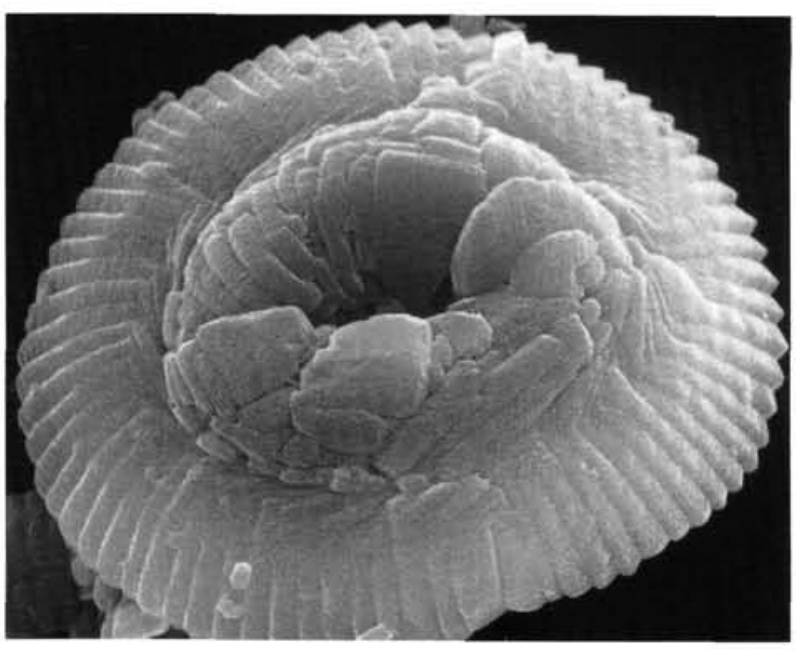

3

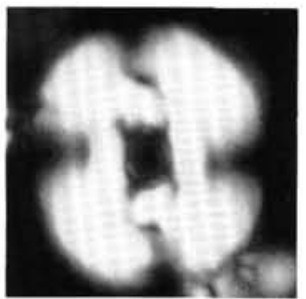

9

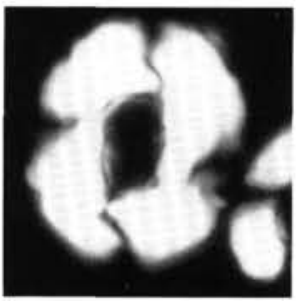

10

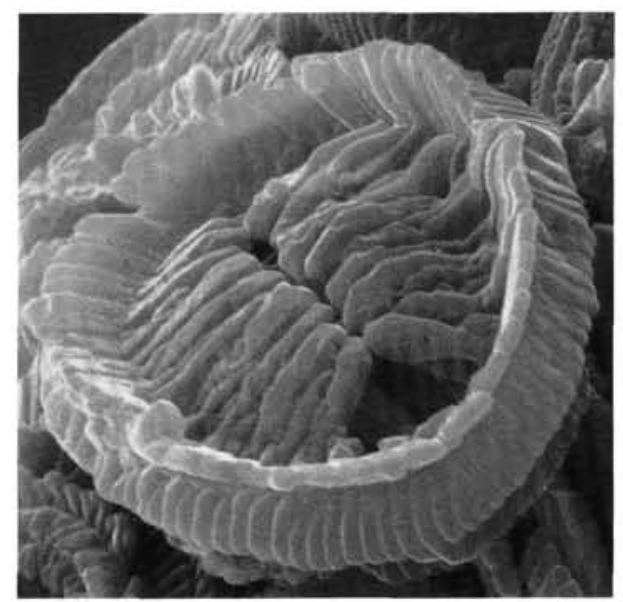

2

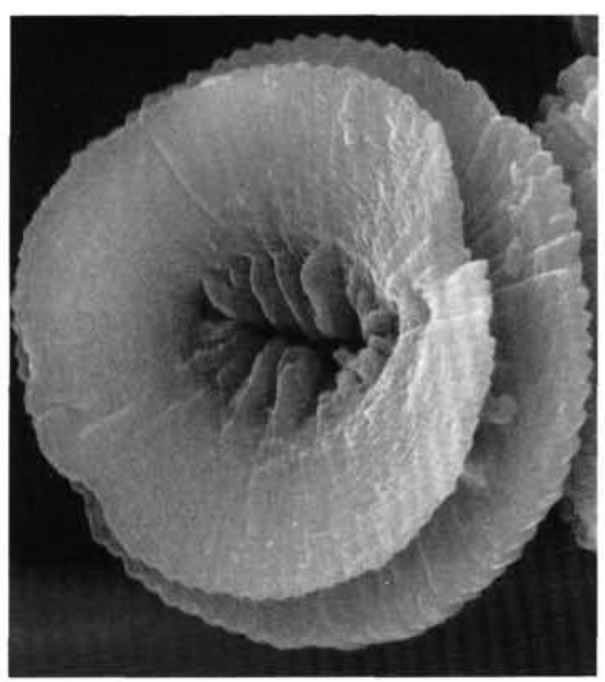

4

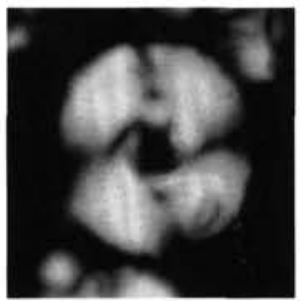

11

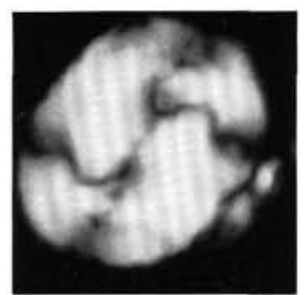

5

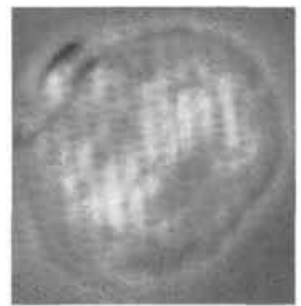

6

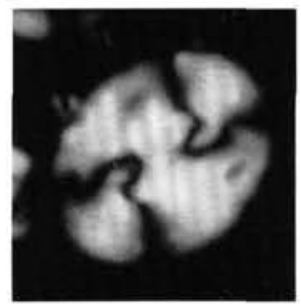

7

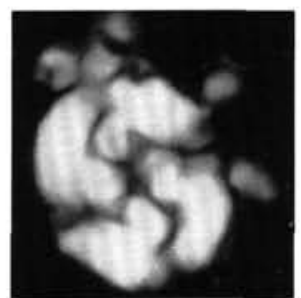

8

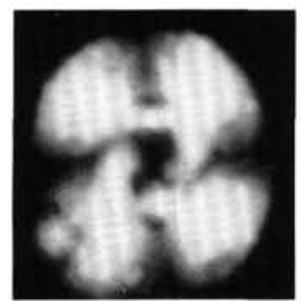

13

Plate 4. 1-2. Reticulofenestra oamaruensis (Deflandre) Stradner and Edwards, SEM, distal view, $\times 5,500$, Sample $113-689 \mathrm{~B}-14 \mathrm{H}-1,130-132 \mathrm{~cm}$. 3-4. Reticulofenestra bisecta (Hay, Mohler, and Wade) Roth, SEM, $\times 6,500$, Sample 113-689B-14H-6, 130-132 cm. (3) Distal view. (4) Proximal view. 5-7. Reticulofenestra perplexa (Burns) Wise, $\times 3,500$, Sample $113-689 \mathrm{~B}-5 \mathrm{H}-2,30-32 \mathrm{~cm}$. (5) Cross-polarized. (6) Same specimen as (5), phase contrast. (7) Cross-polarized. 8. Reticulofenestra hesslandii (Haq) Roth, polarized, $\times 4,000$, Sample 113-689B-7H-6, 29-31 cm. 9. Reticulofenestra gelida (Geitzenauer) Backman, polarized, $\times 3,500$, Sample 113-689B-7H-5, 29-31 cm. 10. Reticulofenestra pseudoumbilica (Gartner) Gartner, cross-polarized, $\times 3,500$, Sample 113-689B-7H, CC. 11-12. Cyclicargolithus floridanus (Roth and Hay) Bukry, polarized, $\times 3,500$. (11) Sample 113-689B-9H-2, 29-31 cm. (12) Sample 113-689B-7H-1, 29-31 cm. 13. Cyclicargolithus abisectus (Müller) Wise, cross-polarized, $\times 3,500$, Sample $113-689 \mathrm{~B}-9 \mathrm{H}-2,29-31 \mathrm{~cm}$. 


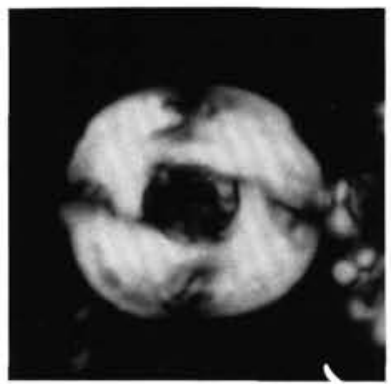

1

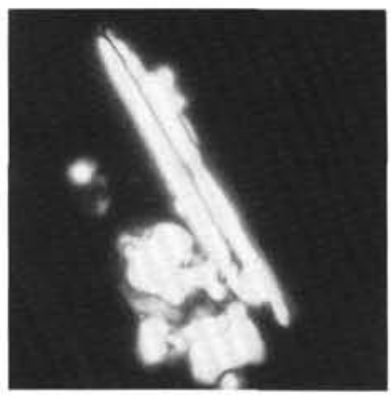

5

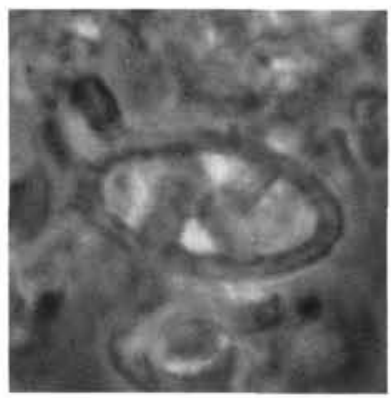

9

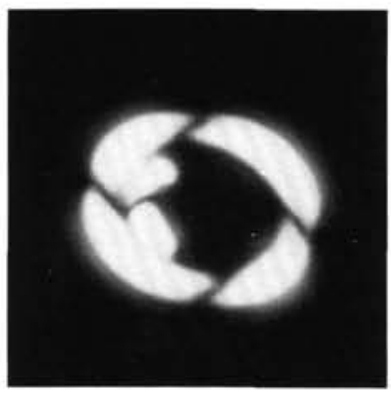

13

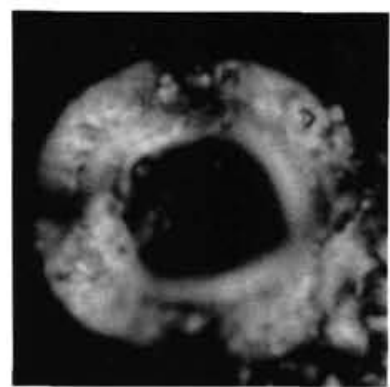

2

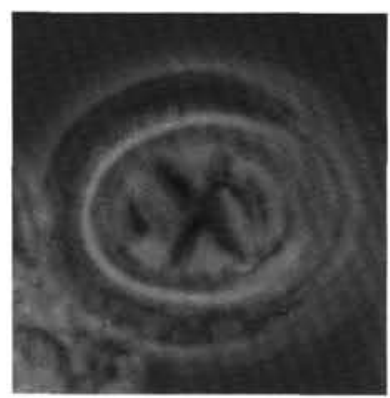

6

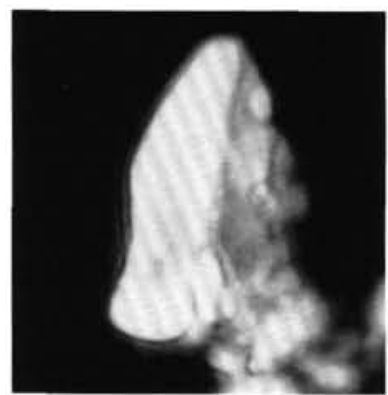

10

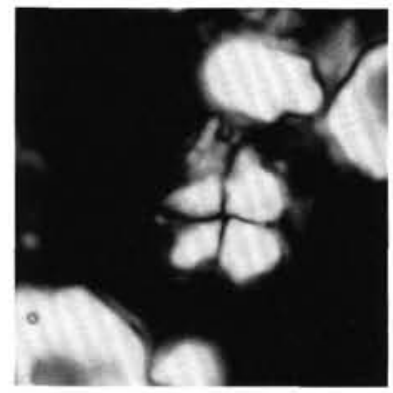

14

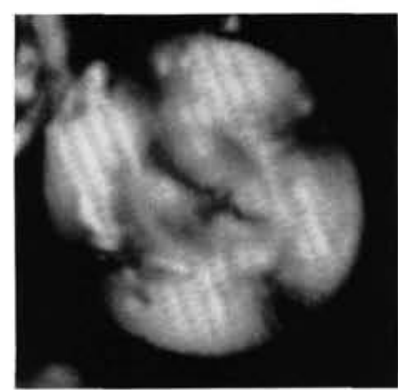

3

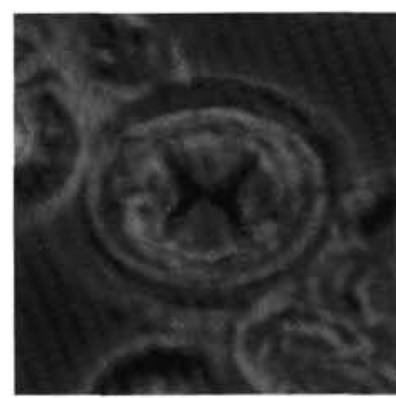

7

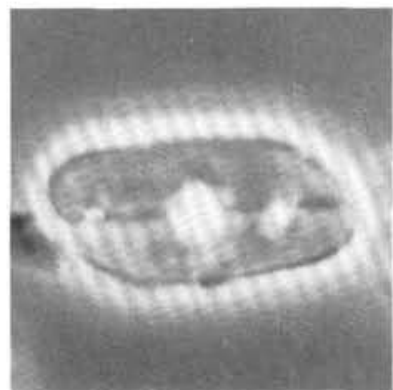

11

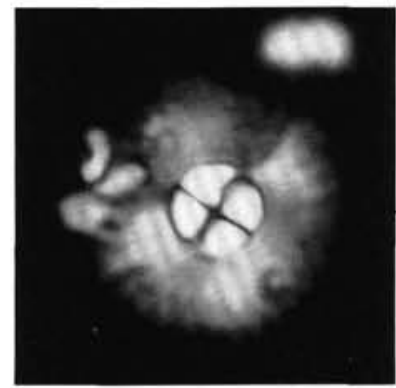

15

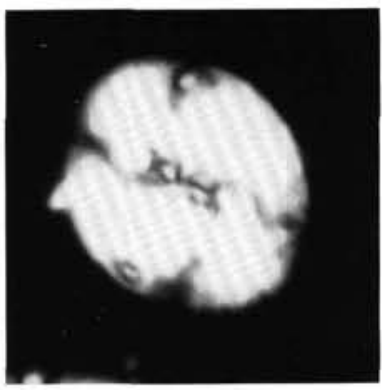

4

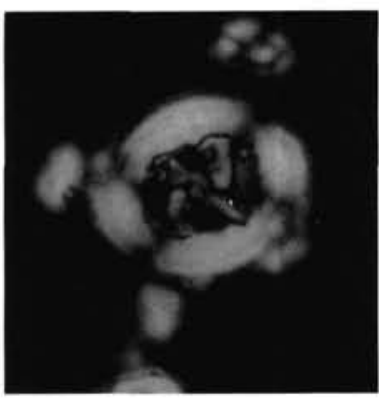

8

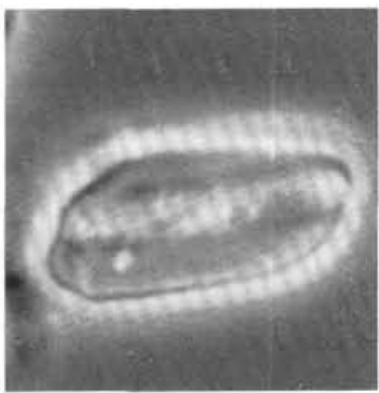

12

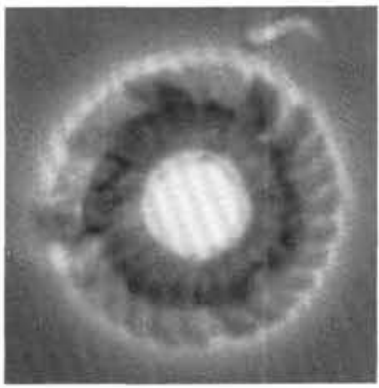

16

Plate 5. 1. Reticulofenestra samodurovii (Hay, Mohler, and Wade) Roth, polarized, $\times 2,200$, Sample 113-689B-16H-6, 29-31 cm. 2. Reticulofenestra umbilica (Levin) Martini and Ritzkowski, polarized, $\times 2,000$, Sample 113-689B-16H-6, 29-31 cm. 3. Reticulofenestra bisecta (Hay, Mohler, and Wade) Roth, cross-polarized, $\times 2,700$, Sample 113-689B-15H-2, 131-133 cm. 4. Reticulofenestra bisecta filewiczii Wise and Wiegand, crosspolarized, $\times 4,000$, Sample 113-689B-15H-2, 131-133 cm. 5. Blackites spinosus (Deflandre and Fert) Hay and Towe, cross-polarized, $\times 2,700$, Sample 113-689B-17H, CC. 6. Chiasmolithus oamaruensis (Deflandre) Hay, Mohler, and Wade, phase contrast, $\times 2,200$, Sample 113-689B-16H-7, 29$31 \mathrm{~cm}$. 7. Chiasmolithus expansus (Bramlette and Sullivan) Gartner, phase contrast, $\times 2,200$, Sample 113-689B-17H-6, 29-31 cm. 8. Chiasmolithus solitus (Bramlette and Sullivan) Locker, phase contrast, $\times 2,500$, Sample 113-689B-17H-6, 29-31 cm. 9. Neococcolithes dubius (Deflandre) Black, phase contrast, $\times 2,500$, Sample $113-689 \mathrm{~B}-17 \mathrm{H}-6,29-31 \mathrm{~cm} . \quad 10$. Zygrhablithus bijugatus (Deflandre) Deflandre, polarized, $\times 3,000$, Sample 113-689B-17H-6, 29-31 cm. 11-12. Isthmolithus recurvus Deflandre, phase contrast, $\times 3,700$, Sample $113-689 \mathrm{~B}-13 \mathrm{H}-4,130-132 \mathrm{~cm}$. 13. Unknown genus and species, cross-polarized, $\times 3,000$, Sample 113-689B-15H-4, $110-112 \mathrm{~cm}$. 14. Sphenolithus moriformis, polarized, $\times 3,000$, Sample 113-689B-17H-5, 29-31 cm. 15-16. Markalius inversus (Deflandre) Bramlette and Martini, same specimen, $\times 3,700$, Sample 113-689B-14H-6, 30-32 cm. (15) Cross-polarized. (16) Phase contrast. 


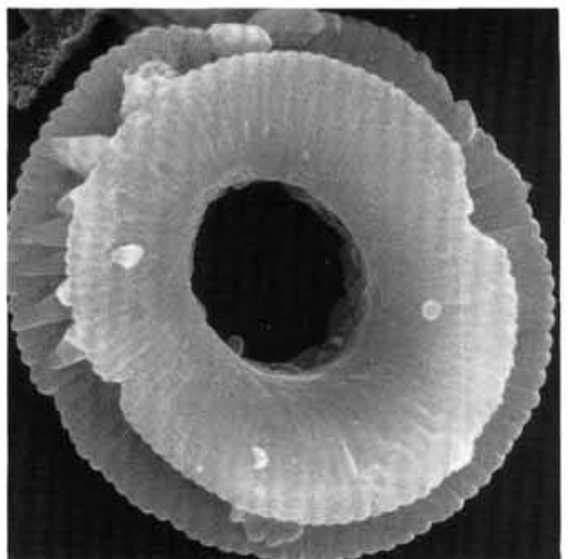

1

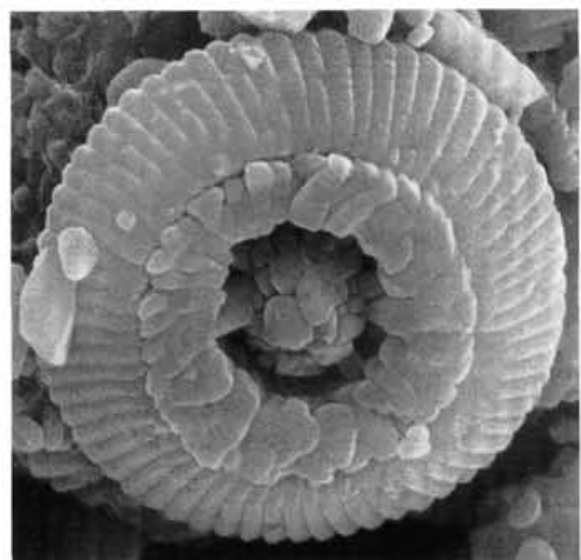

2

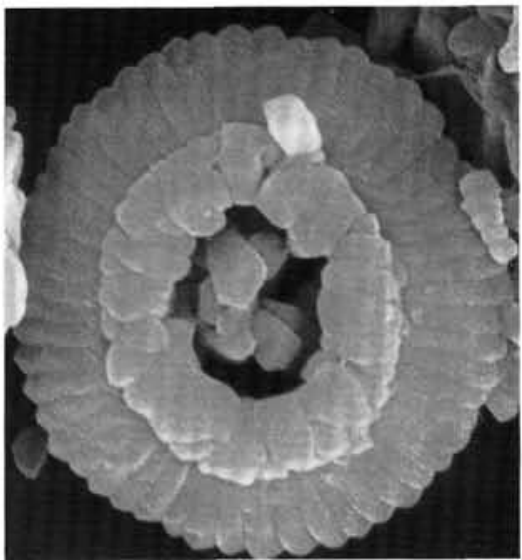

3

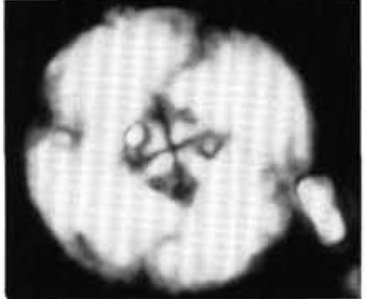

6

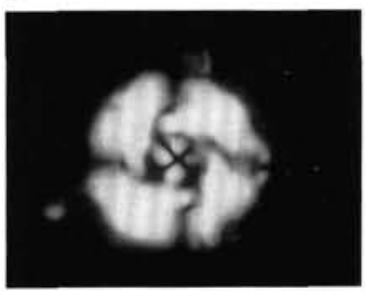

7

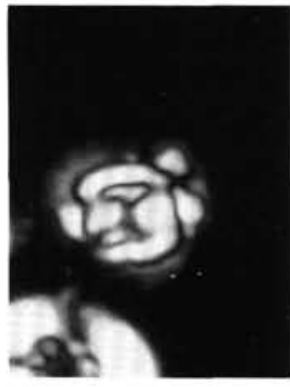

8

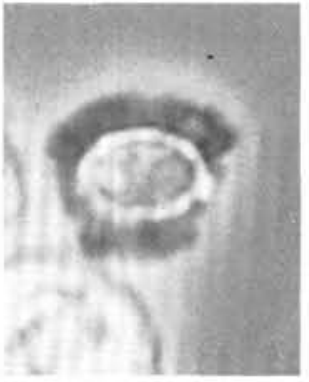

9

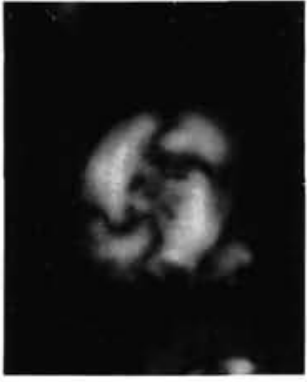

10

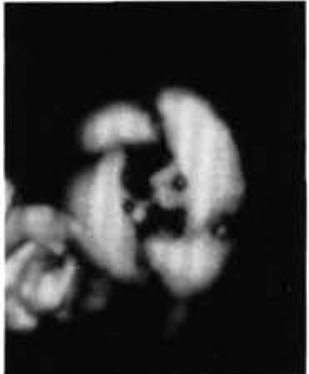

11

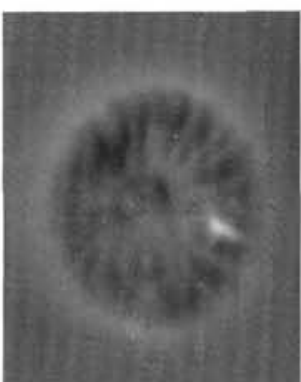

12

Plate 6. 1. Reticulofenestra samodurovii (Hay, Mohler, and Wade) Roth, SEM, $\times 5,000$, Sample 113-689B-14H-6, 130-132 cm. 2-3, 6-7. Reticulofenestra reticulata (Gartner) Roth, Sample 113-689B-15H-3, 131-133 cm. (2) SEM, distal view, $\times 9,000$. (3) SEM, distal view, $\times 6,500$. (6-7) Crosspolarized, $\times 3,500$. 4. Isthmolithus recurvus Deflandre, SEM, typical overgrown specimen in Maud Rise material, $\times 9,500$, Sample $113-689 \mathrm{~B}-14 \mathrm{H}-$ 6, 130-132 cm. 5. Markalius inversus (Deflandre) Bramlette and Martini, SEM, proximal view, $\times 7,000$, Sample 113-689B-15H-6, 131-133 cm. 89. Clausicoccus fenestratus (Deflandre and Fert) Prins, same specimen, $\times 4,000$, Sample $113-689 \mathrm{~B}-16 \mathrm{H}-7$, 29-31 cm. (8) Polarized. (9) Phase contrast. 10-11. Reticulofenestra daviesii (Haq) Haq, polarized, $\times 4,000$, Sample $113-689 \mathrm{~B}-14 \mathrm{H}-6,30-32 \mathrm{~cm}$. 12. Calcidiscus leptoporus (Murray and Blackman) Loeblich and Tappan, phase contrast, $\times 4,000$, Sample $113-689 \mathrm{~B}-7 \mathrm{H}-1,29-31 \mathrm{~cm}$. 